\title{
Applications of asymmetric allylation reactions towards natural product synthesis
}

Philip R. Harsh

West Virginia University

Follow this and additional works at: https://researchrepository.wvu.edu/etd

\section{Recommended Citation}

Harsh, Philip R., "Applications of asymmetric allylation reactions towards natural product synthesis" (2008). Graduate Theses, Dissertations, and Problem Reports. 2671.

https://researchrepository.wvu.edu/etd/2671

This Thesis is protected by copyright and/or related rights. It has been brought to you by the The Research Repository @ WVU with permission from the rights-holder(s). You are free to use this Thesis in any way that is permitted by the copyright and related rights legislation that applies to your use. For other uses you must obtain permission from the rights-holder(s) directly, unless additional rights are indicated by a Creative Commons license in the record and/ or on the work itself. This Thesis has been accepted for inclusion in WVU Graduate Theses, Dissertations, and Problem Reports collection by an authorized administrator of The Research Repository @ WVU. For more information, please contact researchrepository@mail.wvu.edu. 


\title{
Applications of Asymmetric Allylation Reactions
}

Towards Natural Product Synthesis

\author{
Philip R. Harsh
}

Thesis submitted to the Eberly College of Arts and Sciences at West Virginia University in partial fulfillment of the requirements for the degree of

\author{
Master of Science \\ in \\ Chemistry
}

\author{
George O’Doherty, Ph. D., Chair \\ Alan Stolzenberg, Ph. D. \\ John H. Penn, Ph.D.
}

C. Eugene Bennett Department of Chemistry

\author{
Morgantown, West Virginia \\ 2008
}

Keywords: Synthesis, Natural Product, Allylation 


\section{ABSTRACT \\ Applications of Asymmetric Allylation Reactions Towards \\ Natural Product Synthesis}

Philip R. Harsh

A short asymmetric synthesis of $(R)-(+)$-Goniothalamin oxide was developed and synthesized using a Leighton asymmetric allylation reaction and Grubbs ring-closing metathesis. $(R)-(+)$-Goniothalamin oxide is a styryl lactone that exhibits anti-cancer activity against a variety of cancer cell lines including MCF-7, T47D, and MDA-MB231. The methododology of asymmetric allylation is also demonstrated on intermediates of RK-397, which is a 32-membered oxopolyene macrolide with anti-cancer activity. 


\section{ACKNOWLEDGEMENTS}

I would like to thank everyone that has made an influence on my life throughout graduate school even though I thought is was going to be impossible. First and foremost, I would like to think my girlfriend for all her love and support through the last 3 years of graduate school. She has always showed confidence in me even when things were not going the best in the lab. She pushed me to keep going and not give up. I would also like to thank my parents for all they have given me from financial to emotion support. I will always be grateful to my advisor George O'Doherty for providing me the opportunity to do undergraduate research and mentoring me throughout graduate school. I'm grateful that he was there to support me when circumstances became difficult in my graduate studies at West Virginia. I would like to thank Dr. Ronald Smart for showing me other sides of chemistry from environmental to analytical. I also would like to thank Dr. John Penn and Dr. Alan Stolzenberg for being part of my masters committee. I would like to thank all the staff at C. Eugene Bennett Departmental of Chemistry for all their hard work in making the department run smooth day in and day out. The stockroom staff, (JR Taylor, Mike Torres, Eze Dike, and Kevin Dixon) I'm indebted to thank for all their support in helping provide chemicals and making the laboratories runs smoothly. I would like to thank all my colleagues whom I have met in the last three years of graduate school. Special thanks to Matt Mortensen, Haibing Guo, Dong Guo, and Joe Dougherty for all their insight and support. They are truly visionary chemists that have showed me the attitude it takes to be an individual and team chemist and taught me about their respective cultures. 


\section{TABLE OF CONTENTS}

Title Page

i

Abstract

ii

Acknowledgment

iii

Table of Contents

iv

List of Figures

$\mathbf{v}$

List of Schemes

$\mathbf{v}$

Chapter Outline

vi 


\section{LIST OF FIGURES}

Figure 1: Transition State of Brown Allylation 3

Figure 2: Transition State of Roush Asymmetric Allylation 4

Figure 3: Goniothalamin-Based Derivatives $\quad \mathbf{8}$

Figure 4: RK-397, 32-membered oxopentaene antibiotic $\mathbf{1 5}$

\section{LIST OF SCHEMES}

Scheme 1: Generic Chiral Allylation Reaction 1

Scheme 2: Common Asymmetric Allylation Reactions 2

Scheme 3: Brown Asymmetric Allylation $\quad 2$

Scheme 4: Roush Asymmetric Allylation $\quad 4$

Scheme 5: Leighton Asymmetric Allylation $\quad \mathbf{5}$

Scheme 6: Leighton Allylation of Chiral Aldehydes 6

Scheme 7: Keck and Carreira Catalytic Asymmetric Allylations $\quad 7$

Scheme 8: Retrosynthesis Analysis of Marko's Synthesis $\quad \mathbf{1 0}$

Scheme 9: Retrosynthesis Analysis of Bose's Synthesis 11

Scheme 10: Retrosynthetic Approach Towards (R)-(+)-Goniothalamin oxide 12

Scheme 11: Stereoselective Synthesis of Epoxide 3a \& 3b 12

$\begin{array}{ll}\text { Scheme 12: Acylation of epoxides } & 13\end{array}$

Scheme 13: Ring-Closing Metathesis of Diene (4a) 14

Scheme 14: Ring-Closing Metathesis of Diene (4b) 14

Scheme 15: Retrosynthesis of $R K-397 \quad 16$

Scheme 16: Synthesis of Leighton Allylation Intermediates Towards RK-397 17 
Scheme 17: Ir-Catalyzed Transfer Hydrogenative Allylation

Scheme 18: Synthesized Alcohols

Scheme 19: Synthesized Aldehydes

Scheme 20: Leighton Allylation Products

\section{CHAPTER OUTLINE}

CHAPTER I:

Application of Allylation Reactions towards (R)-(+)-goniothalamin oxide

1.1 Introduction: Previous Asymmetric Allylation Reactions 1

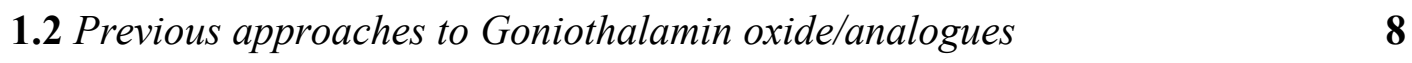

1.3 Total synthesis of $(R)-(+)-$ Goniothalamin oxide $\quad 11$

CHAPTER II:

\section{Allylation reactions of RK-397}

2.1 Background of Oxopolyene Macrolide Antibiotic RK-397 15

2.2 Outline of Krische Catalytic Asymmetric Allylation 18

2.3 Synthesized Intermediates for Krische Allylation and Future Work 19

CHAPTER III:

\section{Experimental Section}

3.1 General Information: Instrumentation, Materials, Manipulation 22

3.2 References $\quad 38$ 


\section{CHAPTER I}

\subsection{Introduction: Previous Asymmetric Allylation Reactions}

Asymmetric allylation reactions have been the focus of several research groups for the past few decades. Throughout this period, the groups of Brown, Keck, Roush, and Leighton have most notably developed various asymmetric allylation reagents that have shown to add allyl groups with high enantioselectivity for a variety of aldehydes. Scheme 1 shows a generic asymmetric allylation of an achiral aldehyde where the chiral reagent selectively forms one of the two possible enantiomeric homoallylic alcohols.

\section{Scheme 1: Generic Chiral Allylation Reaction}

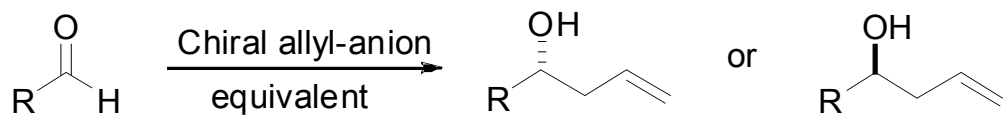

The reaction conditions of each type of asymmetric allylation reaction are quite different in several aspects including: catalytic vs. stoichiometric, chiral reagents vs. chiral Lewis acid, and reaction conditions (time/temperature). Outlined in Scheme 2 are the different reaction types and conditions for the most common asymmetric allylation reagents. 
Scheme 2: Common Asymmetric Allylation Reactions

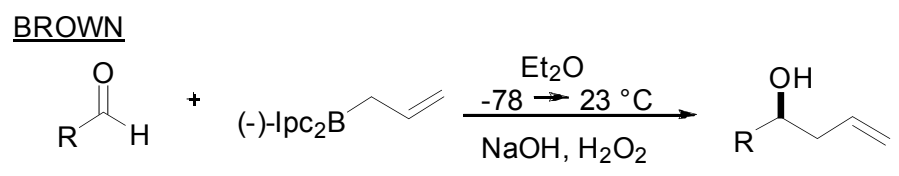

CARREIRA/GAUTHIER

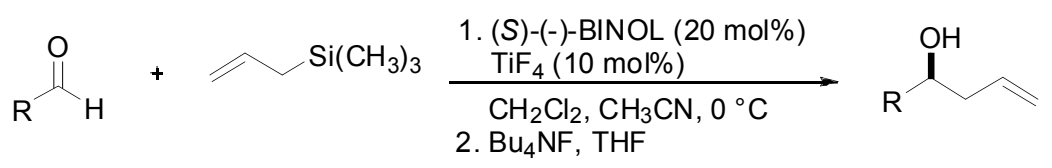

$\underline{\text { ROUSH }}$

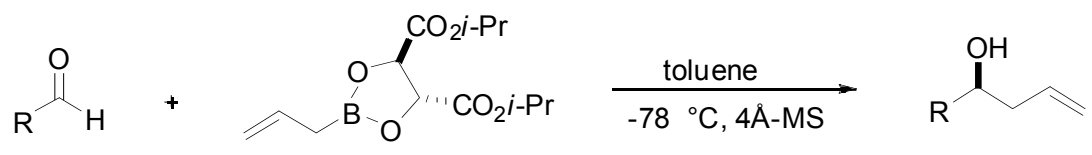

KECK

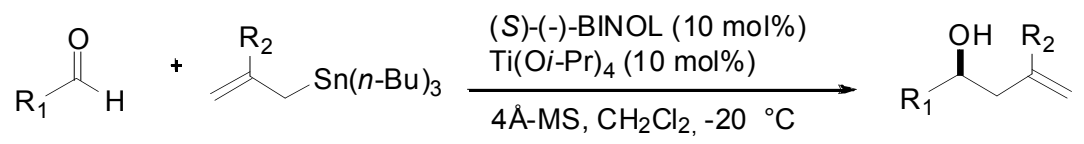

LEIGHTON

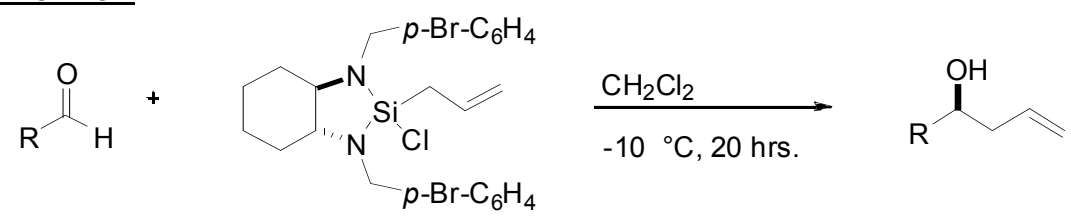

Brown was one of the first to recognize the potentiality of this reaction. Brown and co-workers explored the asymmetric allylation reactions using a chiral allylborane reagent, Ipc ${ }_{2}$ Ballyl (Scheme 3 ). The Brown reagent, Ipc ${ }_{2}$ Ballyl, is made by a three-step procedure that begins with the hydroboration of the natural product $\alpha$-pinene, from which it draws its chirality. ${ }^{1}$

Scheme 3: Brown Asymmetric Allylation

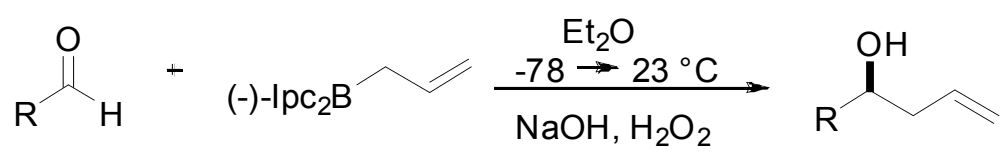


The Brown allylation of achiral aldehydes, in general, affords secondary homoallylic alcohols with high enantioselectivity (85-99\%ee) for a variety of substrates. The reaction can be dependent upon temperature under $-78{ }^{\circ} \mathrm{C}$ being the most common reaction condition. Similarly, it is important to generate the Brown reagent without the presence of any magnesium salts, which can lower the enantioselectivity/reactivity of the reaction. Thus in the absence of magnesium salts, the typical allyborylation of an aldehyde can occur almost instantaneously at $-78^{\circ} \mathrm{C}$.

Brown also showed that the allylation of aldehydes proceeded through a chair-like Zimmerman-Traxler transition state. Thus E-substituted allyl reagents give antihomoallylic alcohols and Z-substituted reagents give syn-homoallylic alcohols. Figure 1 shows Brown's proposed transition state for the allylation where the R-group of the aldehyde occupies the equatorial position allowing minimal steric interactions between the axial isopinocamphenyl (Ipc) ligands and the allyl group. ${ }^{2}$

Figure 1: Transition State of Brown Allylation

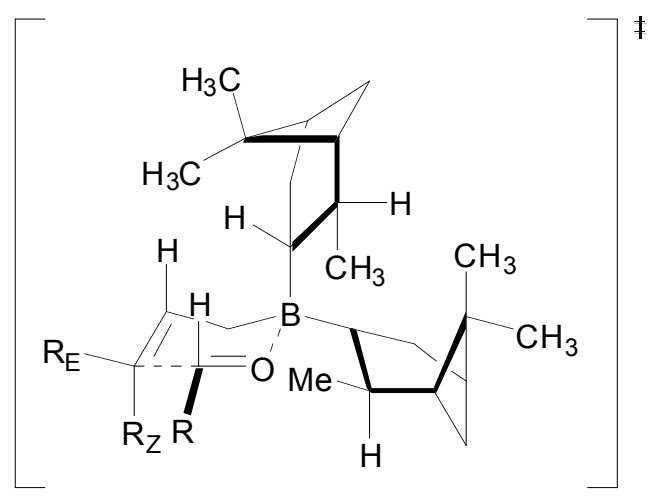

At about the same time as the Brown group, the Roush group also developed an asymmetric allylation reagent. Roush and coworkers utilized a boron-based reagent for 
asymmetric allylation reactions; however, it is quite different in many aspects from the Brown reaction. Scheme 4 shows a typical asymmetric allylation of an aldehyde with the Roush's allyl boronate complex.

Scheme 4: Roush Asymmetric Allylation

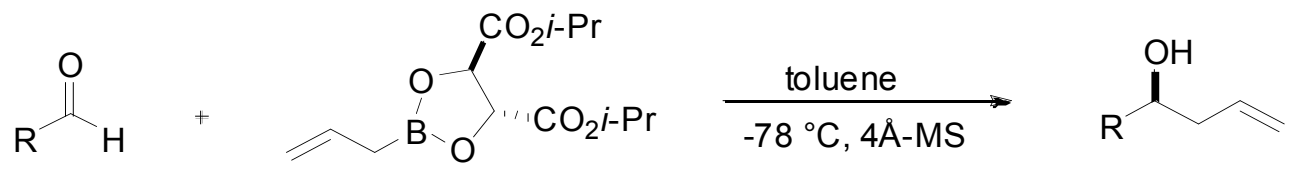

The allyl boronate reagent that Roush employs in the allylation reaction is considerably more stable than the allyl-diisopinocamphenyl reagent that Brown used. This has very important advantages for allowing the reagent to be purified by distillation, if necessary. The major downfall of the Roush's allylation reaction is that it produces homoallylic alcohols with lower enantioselectivities (70-90 \%ee) compared to Brown's. The enantioselectivities are diminished by the presence of water and thus the addition of $4 \AA$ molecular sieves is important to achieve the highest stereoselectivity. ${ }^{3}$

Figure 2: Transition State of Roush Asymmetric Allylation

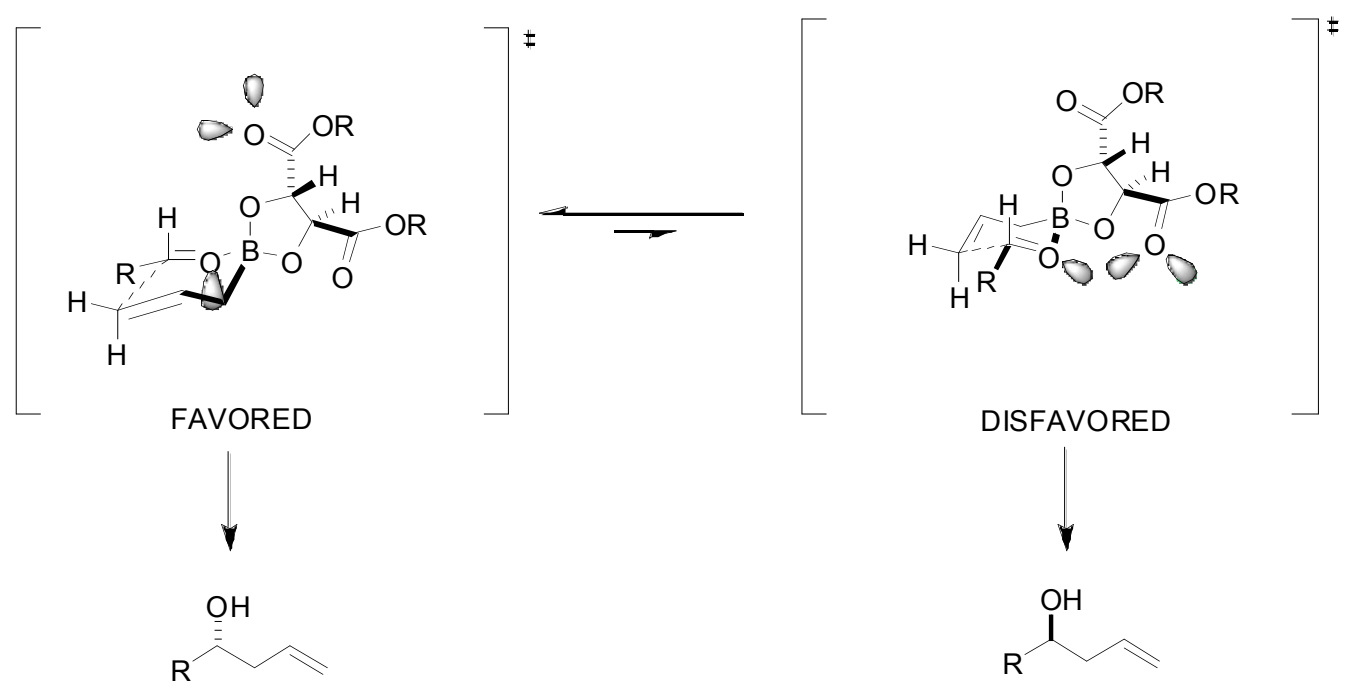


Roush proposed that the selectivity in the allyborylation reactions was due to the favored transition state that minimized the lone-pair/lone-pair interactions between the aldehyde and the ester carbonyl. Figure 2 shows these transition states and the desired enantioselective product. $^{3}$

Leighton discovered that silicon could also be used as an allylation reagent when it was constrained in a five-membered ring by 1,2-aminoalcohols, 1,2-diols, and 1,2diamines. He suggests this is due to the increased Lewis acidity imparted by the heteroatoms and ring strain. His hypothesis is supported by the fact that the simple trichloroallylsilane has insufficient Lewis acidity for uncatalyzed allylation of aldehydes. Scheme 5 outlines a typical Leighton allylation using a chiral silicon 1,2-diamine reagent.

\section{Scheme 5: Leighton Asymmetric Allylation}

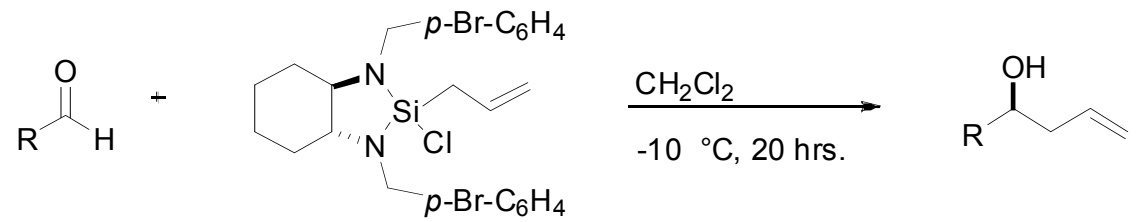

Leighton and coworkers optimized the silicon reagent (shown in reaction above) by replacing an original benzyl groups with a para-substituted bromo-benzyl groups. This transformation of the silicon reagent was very important to increase the enantioselectivity (90-99 \%ee) and yields (70-95\%) for the allylation of aliphatic, aromatic, and conjugated aldehydes. ${ }^{4}$ Leighton and coworkers extended applications of the reagent by applying onto chiral aldehydes. Scheme 6 outlines a typical Leighton allylation using both enantiomers of the silicon reagent (1) on a chiral substate. Thus, 
Leighton methodology demonstrates high reagent control over substrate control for aldehydes with chiral centers in the beta-position. ${ }^{4}$

Scheme 6: Leighton Allylation of Chiral Aldehydes

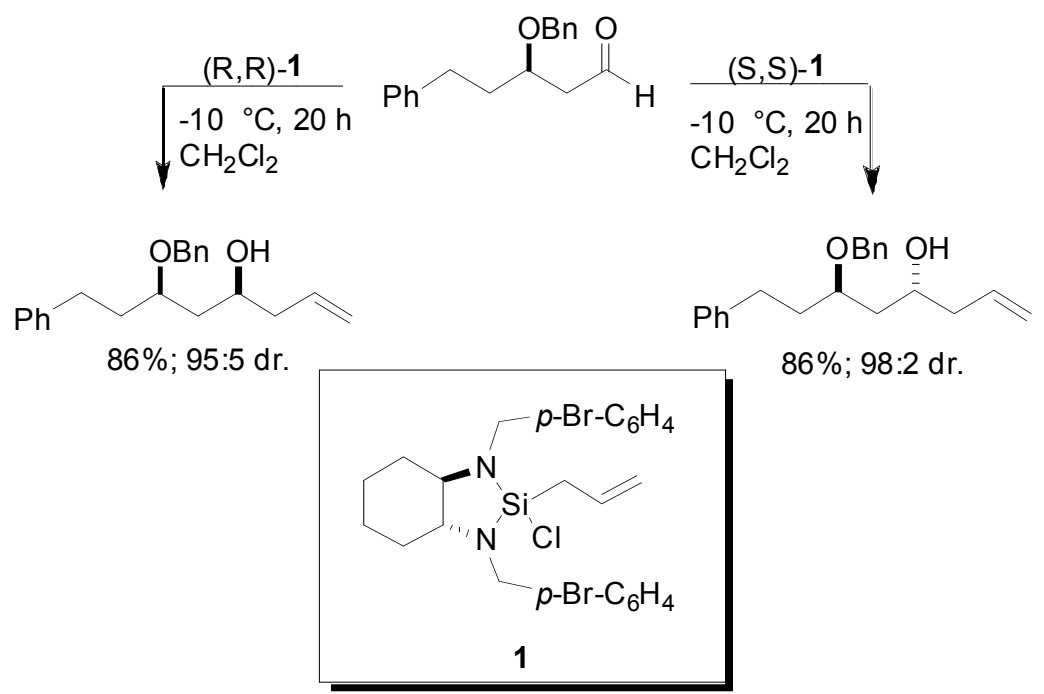

Keck and Carreira research groups have explored the development of a catalytic asymmetric allylation reaction. The key difference between the approaches of these two research groups is that Keck employs an allyl-tin based reagent while Carreira uses an allyl-silane reagent. The scheme 7 shows the two catalytic asymmetric allylation reactions to give homoallylic alcohols. ${ }^{5,6,7}$ 
Scheme 7: Keck and Carreira Catalytic Asymmetric Allylations

\section{CARREIRA/GAUTHIER}

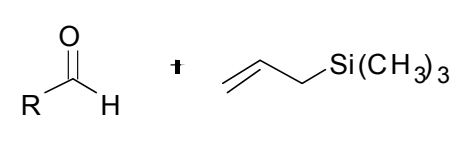

1. (S)-(-)-BINOL $(20 \mathrm{~mol} \%)$

$\underset{\mathrm{TiF}_{4}(10 \mathrm{~mol} \%)}{\mathrm{CH}_{2} \mathrm{Cl}_{2}, \mathrm{CH}_{3} \mathrm{CN}, 0{ }^{\circ} \mathrm{C}}$

2. $\mathrm{Bu}_{4} \mathrm{NF}, \mathrm{THF}$

KECK

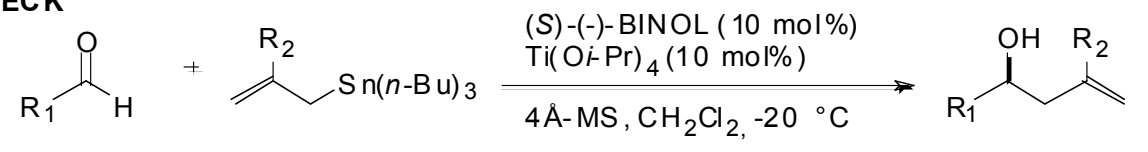

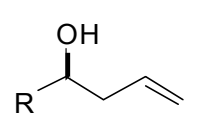

(1)

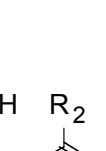

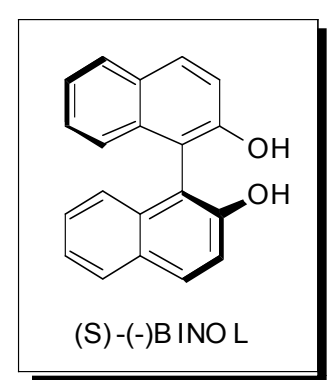

Both reactions are catalytic in chiral Lewis acids, which are generated by the titanium specie and the chiral ligand (BINOL) that is available commercially in both enantiomers. It is important to note that in Carreira allylation reactions, the addition of a small amount of $\mathrm{CH}_{3} \mathrm{CN}$ is important to keep the polymeric $\mathrm{TiF}_{4}$ soluble. The enantioselectivities for both reactions are competitive with each other with enantioselectivities in the range of 70 to $95 \%$.

Another important factor to mention about each of the reactions is the toxicity of the tin reagent compared to silicon reagent. The health effects of tin can range from acute to long term depending on the exposure and type of the tin reagent one is exposed to. Triethylstannane has been recognized as the most dangerous form of tin due to the short hydrogen bonds. Tin compounds become considerably less toxic as the hydrogen bond is lengthened. ${ }^{8} \quad$ Health effects that are associated with tin are: liver damage, brain damage, and malfunction of the immune system. ${ }^{8}$

Silicon, on the other hand, is relatively less harmful to humans. Silicon concentrates in no particular organ of the body but is found in the skin and tissues. Silicon may cause health affects including: respiratory tract infection and irritation of skin and eyes. ${ }^{9}$ 


\subsection{Previous approaches to Goniothalamin oxide/analogues}

There have been several syntheses of Goniothalamin and Goniothalamin oxide derivatives. Goniothalamin was first isolated in 1967 from the bark of Cryptocarya caloneura and was assigned to have $(S)$-stereochemistry. ${ }^{10}$ However, the stereochemistry was revised many years later to the $(R)$ configuration. Several derivatives of Goniothalamin have been discovered from a variety of tropical/subtropical plants including; Cryptocarya moschata, ${ }^{11}$ Bryonopsis laciniosa, ${ }^{12}$ and various Goniothalamus ${ }^{13}$ species. These natural products have shown cytotoxicity on a variety of cells lines including: MCF-7, T47D, and MDA-MB-231 (breast carcinoma); HeLa (human cervical carcinoma); HL-60 (leukemia carcinoma); Caov-3 (ovarian carcinoma). Figure (3) shows a variety of Goniothalamin-based derivatives. ${ }^{14}$

Figure 3: Goniothalamin-Based Derivatives

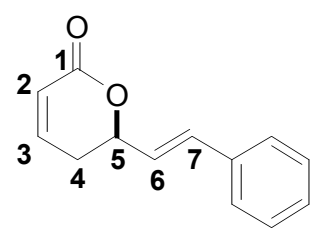

(R)-(+)-goniothalamin

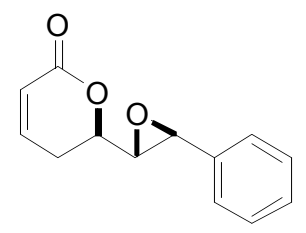

(R)-(+)-goniothalamin oxide

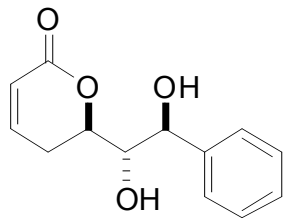

(+)-4-dehydoxygoniotriol

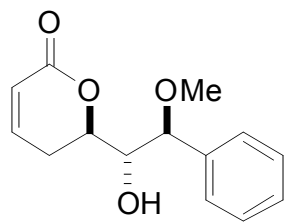

(+)-8-methoxygoniodiol

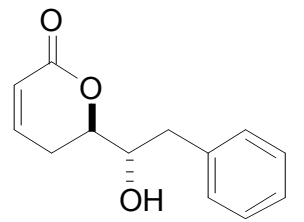

(+)-8-deoxygoniodiol 
There are two total syntheses of $(R)-(+)$-goniothalamin and $(R)-(+)$-goniothalamin oxide that have been recently reported by Marko and Bose respectively. ${ }^{14,15}$ Note that several other research groups have synthesized Goniothalamin and Goniothalamin analogues but the emphasis of this thesis will be on the two syntheses mentioned above with relevance to their work. ${ }^{15}$ Marko and coworkers, employed a sulfoxide-modified Julia olefination starting from optically pure glycidol ether. In contrast, Bose and coworkers utilized a ring-closing metathesis and Jacobsen's hydrolytic kinetic resolution of a racemic epoxide.

In 2006, Marko and coworkers completed the total synthesis of $(R)-(+)-$ goniothalamin and $(R)-(+)$-goniothalamin oxide in five and six steps $(51-55 \%$ overall yield) respectively (Scheme 8). 
Scheme 8: Retrosynthesis Analysis of Marko's Synthesis
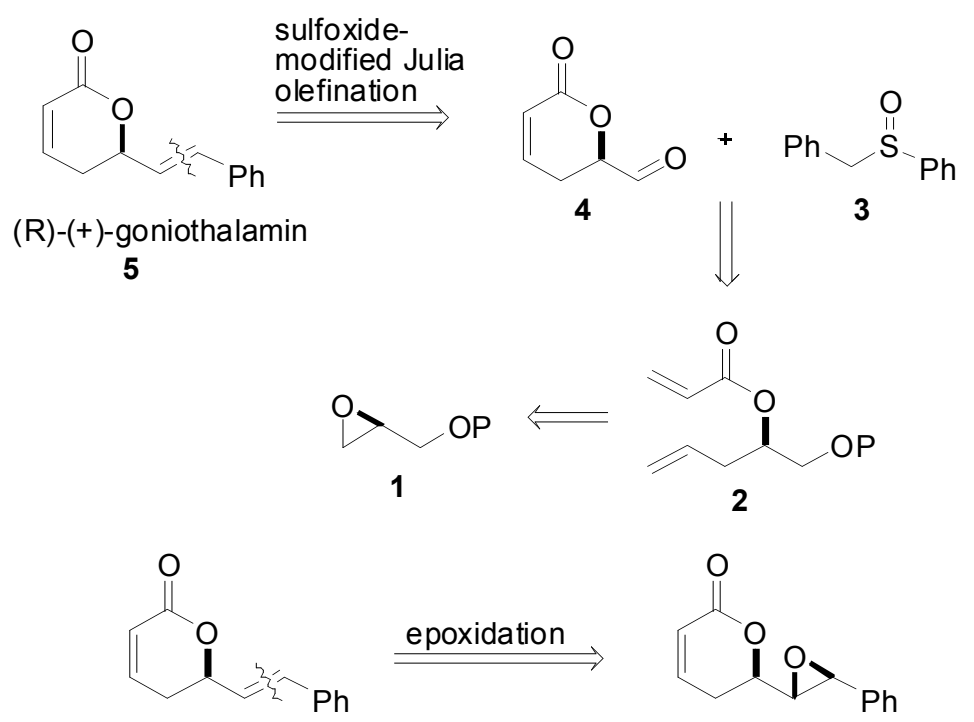

(R)-(+)-goniothalamin

(R)-(+)-goniothalamin oxide

6

(R)-(+)-goniothalamin was completed by a connection at the C6-C7 bond by employing a sulfoxide modified Julia olefination on aldehyde $\mathbf{4}$ and sulfoxide $\mathbf{3}$. The aldehyde 4 was assembled from the protected diene 2 by a ring closing metathesis. Ring opening and acylation of the optically pure protected glycidol $\mathbf{1}$ afforded the protected diene 2. (R)-(+)-goniothalamin oxide 6 was accomplished by epoxidation of $(R)-(+)$ goniothalamin $\mathbf{5}^{14}$

Bose's synthesis (Scheme 9) achieved the natural products of $(R)-(+)$ goniothalamin and $(R)-(+)$-goniothalamin oxide in six steps with $65 \%$ overall yield. 
Scheme 9: Retrosynthesis Analysis of Bose's Synthesis

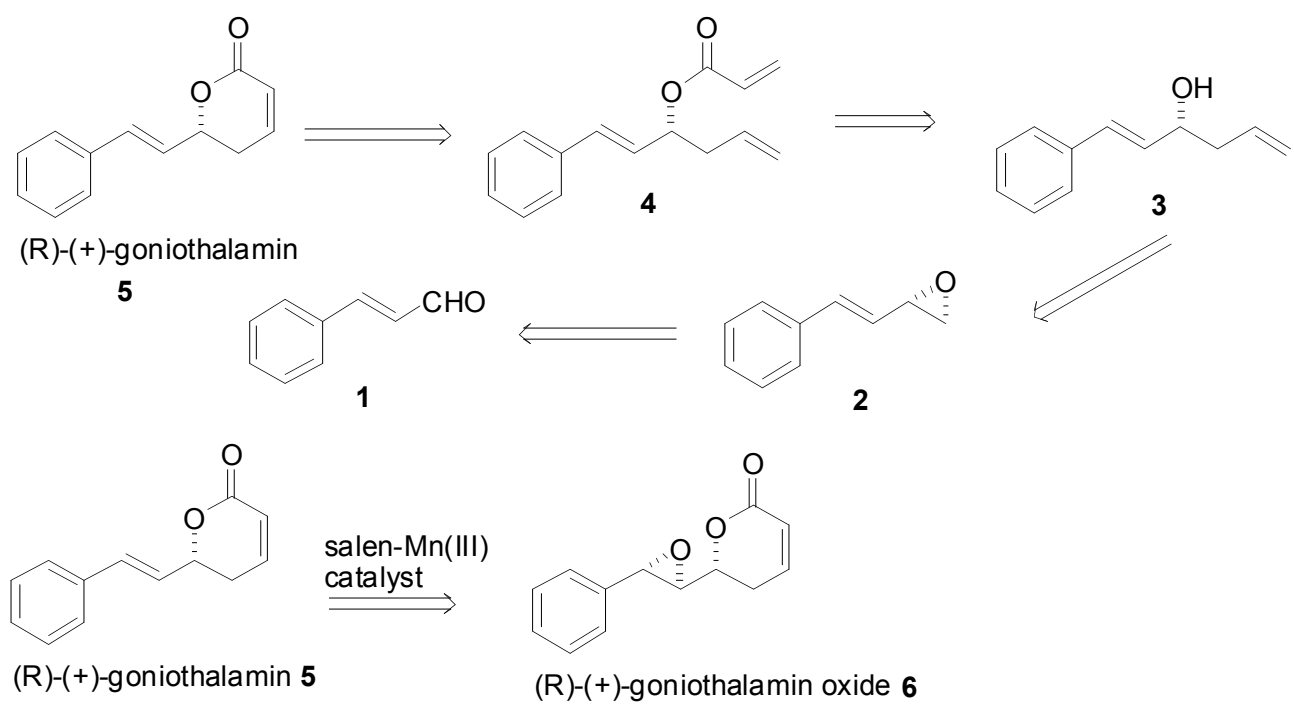

Bose synthesized the two natural products shown in Scheme 9 by a ring closing metathesis of triene 4 using Grubbs' $1^{\text {st }}$ generation catalyst. The triene 4 was afforded by an acylation of alcohol $\mathbf{3}$ which was synthesized from the chiral epoxide 2. The chiral epoxide 2 was furnished by using an olefination followed by epoxidation of transcinnamaldehyde 1 followed by a Jacobsen hydrolytic kinetic resolution (HKR) of the racemic epoxide. The downfall of using Jacobsen HKR is that half of the starting epoxide is converted to a chiral epoxide with the opposite stereochemistry of the natural product. ${ }^{16}$ Compound $\mathbf{6}$ was synthesized by using Jacobsen's expoxidation from $\mathbf{5}$.

\subsection{Total synthesis of $(R)-(+)$-goniothalamin oxide}

Our approach for the total synthesis of $(R)-(+)$-goniothalamin oxide is much similar to Bose's synthesis, in that we go through the same homoallylic alcohol. The retrosynthesis in Scheme 10 shows the similarities and the differences in the two syntheses. 
Scheme 10: Retrosynthetic Approach Towards (R)-(+)-goniothalamin oxide

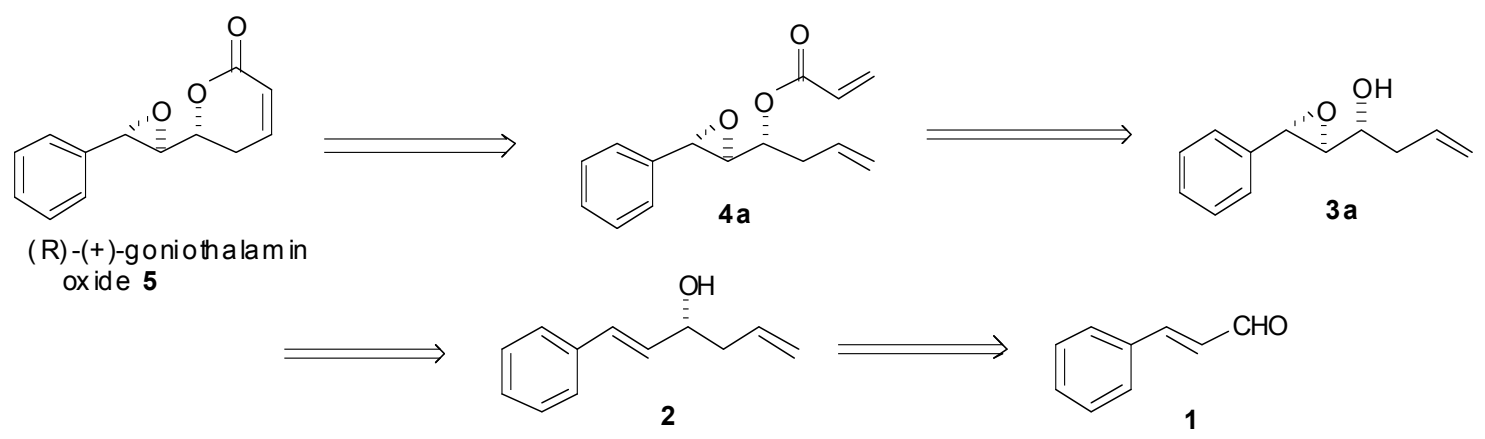

Our route to $(R)-(+)$-goniothalamin oxide also relies upon a ring-closing metathesis of the diene $\mathbf{4}$ using the Grubbs I catalyst. Acylation of the secondary alcohol of epoxide 3a could afford the diene 4 that would be used in the ring-closing metathesis. Epoxide 3a could be prepared by a Leighton allylation of trans-cinnamaldehyde $\mathbf{1}$ followed by an diastereoselective epoxidation of the internal double bond of the allylproduct 2 .

Scheme 11: Stereoselective Synthesis of Epoxide $\mathbf{3} \boldsymbol{a} \& \mathbf{3 b}$
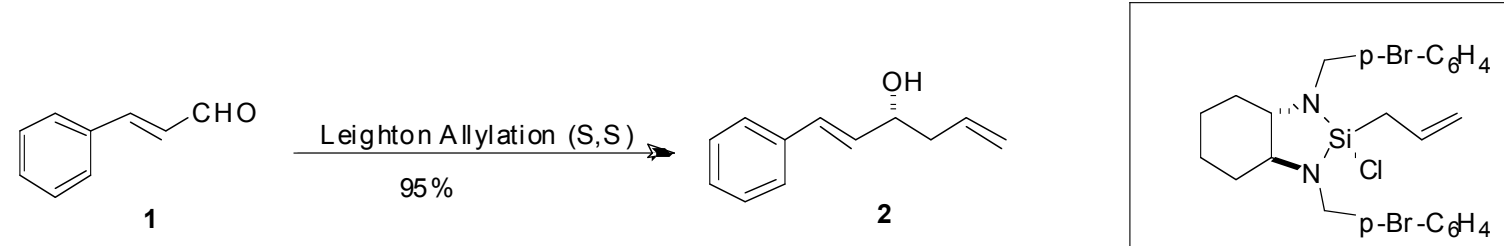

(S,S)-Leighton Reagent (7)

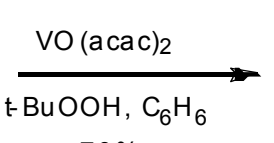

$70 \%$

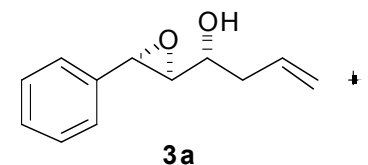

$3 a$

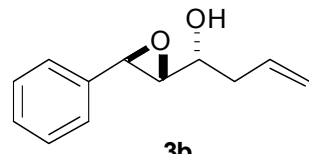

dr: $10: 1$
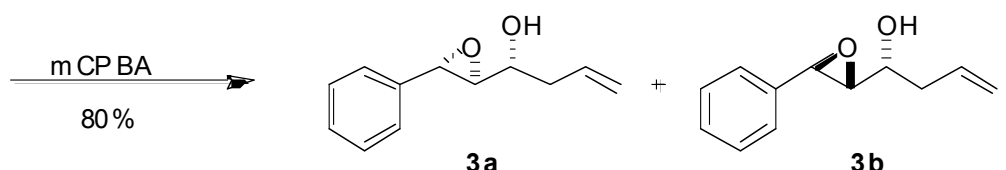

$3 \mathbf{a}$

3b

dr: 1.5:1 
The total synthesis of $(R)-(+)$-goniothalamin oxide was accomplished by using commercially available starting material trans-cinnamaldehyde 1. Enantioselective allylation of trans-cinnamaldehyde $\mathbf{1}$ was completed using the (S,S)-Leighton reagent 7 to furnish secondary alcohol $\mathbf{2}$ in $95 \%$ yield with excellent stereoselectivity. The stereoselective epoxidation of the internal double bond was completed by using $\mathrm{VO}(\mathrm{acac})_{2} / t-\mathrm{BuOOH}$ in refluxing benzene to diastereoselectively furnish the undesired product (3b) in the ratio of 10:1 (Scheme 11). However, the desired product (3a) could be furnished at a greater yield and higher diasteroselectivity using a $m C P B A$ epoxidation of 2 .

It is important to note that the mixture of diastereomers were inseparable by flash chromatography at this point, but could be cleanly separated following the acylation reaction (Scheme 12).

Scheme 12: Acylation of epoxides

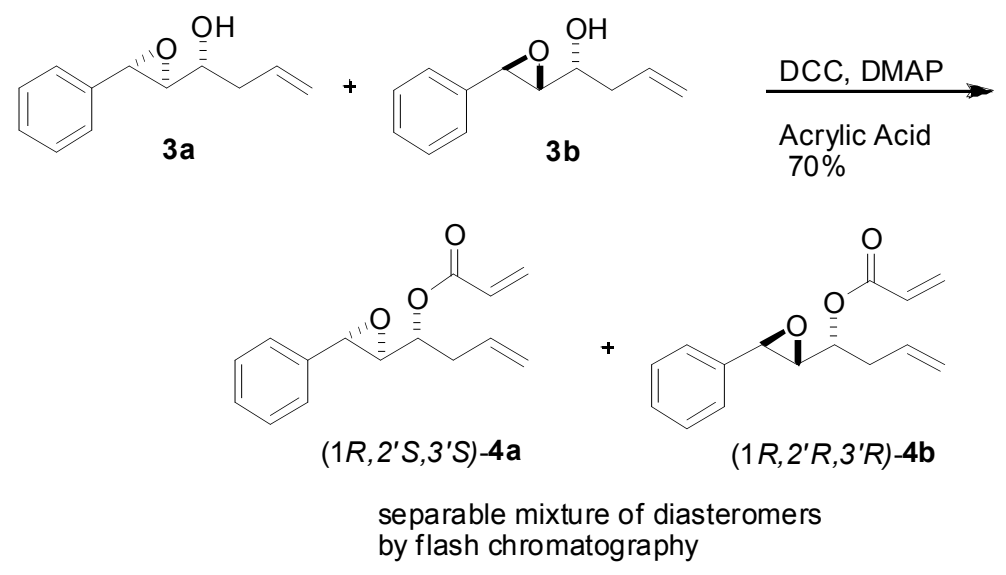

Thus, the mixture of epoxides was acylated using acrylic acid, DMAP/DCC in $\mathrm{CH}_{2} \mathrm{Cl}_{2}$ (70\% yield). The mixture of acylated products $\mathbf{4 a} / \mathbf{4} \mathbf{b}$ was then easily separated by flash chromatography to give two pure diastereomers. The $\left(1 R, 2^{\prime} S, 3^{\prime} S\right)$ diastereomer 
4a was used to complete the total synthesis of $(R)-(+)$-goniothalamin oxide by means of a ring-closing metathesis (Scheme 13), which was induced upon exposure of $\mathbf{4 a}$ to the Grubbs $1^{\text {st }}$ generation catalyst.

Scheme 13: Ring-Closing Metathesis of Diene 4a
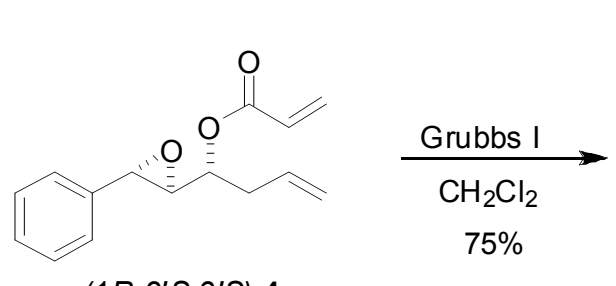

$\left(1 R, 2^{\prime} S, 3^{\prime} S\right)-4 a$

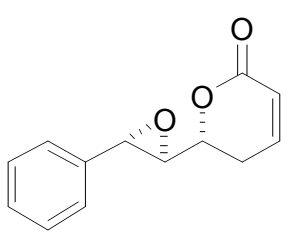

$(R)-(+)$-Goniothalamin Oxide 5

The other diastereomer $\left(1 R, 2^{\prime} S, 3^{\prime} S\right)$-4b was also subject to a ring-closing metathesis using Grubbs $1^{\text {st }}$ generation catalyst (Grubbs I) to give the diastereomeric product of $(R)-(+)$-goniothalamin oxide 6 (Scheme 14). This diastereomer could be prepared in a slightly higher yield replacing the diastereoselective directed epoxidation of 2 with an unselective $m$ CPBA epoxidation.

Scheme 14: Ring-Closing Metathesis of Diene $4 \boldsymbol{b}$

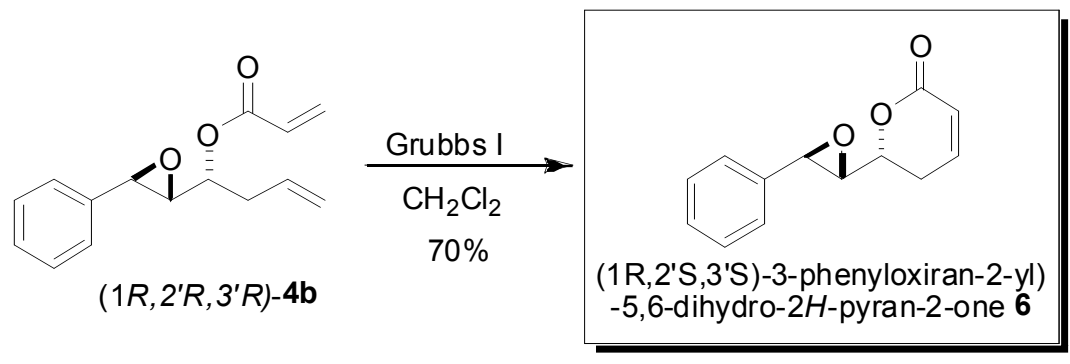

The total synthesis of $(R)-(+)$-goniothalamin oxide 5 and $(1 R, 2 ' S, 3 ' S)-3-$ phenyloxiran-2-yl)-5,6-dihydro-2H-pyran-2-one 6 were completed in four steps in 35\% and $33 \%$ overall yield respectively. Both syntheses provide material with physical and spectral date that matched the data reported in the literature. ${ }^{14}$ 


\section{CHAPTER II}

\subsection{Background of Oxopolyene Macrolide Antibiotic RK-397}

RK-397 (Figure 4) is a 32-membered oxopentaene macrolide antibiotic that was isolated and characterized from a Japanese soil bacterium in 1993 by Osada and coworkers. ${ }^{16}$ The macrolide processes antifungal properties along with potent oncotoxicity in a variety of cancer cell lines. ${ }^{17}$ Due to this interesting activity and the unique structure of RK-397, many research groups have completed total and formal syntheses of this compound including: McDonald ${ }^{18}$, Denmark ${ }^{19}$, Sammakia $^{20}$ and O’Doherty. ${ }^{20}$

Figure 4: $R K-397,32-$ membered oxopentaene antibiotic

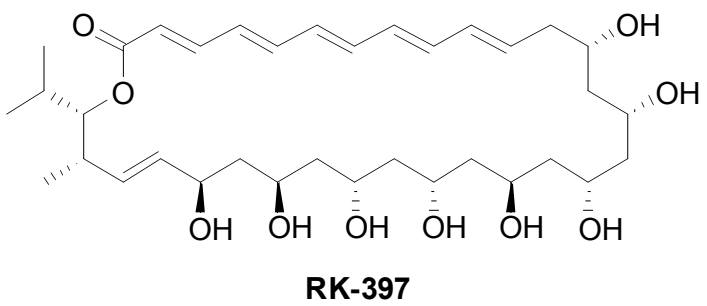

O’Doherty's formal synthesis of RK-397 utilizes two dienoate asymmetric hydration reaction sequences ( 7 to $\mathbf{6}$ and $\mathbf{8}$ to 5 ) to set the initial asymmetry of the convergent synthesis. In addition, several highly diastereoselective reactions were used to control the remaining stereocenters of RK-397. These reactions included two reagent controlled Leighton allylation reactions, as well as three substrate controlled intramolecular hydration reactions and one substrate controlled aldol reaction $(\mathbf{4}+\mathbf{5}$ to $\mathbf{3}$, Scheme 15$)^{21}$ 
Scheme 15: Retrosynthesis of RK-397

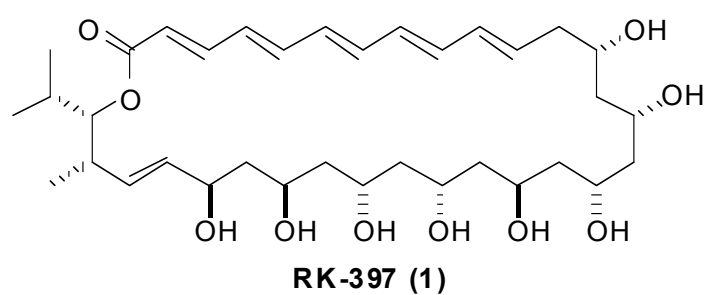

$\int$ Denmark
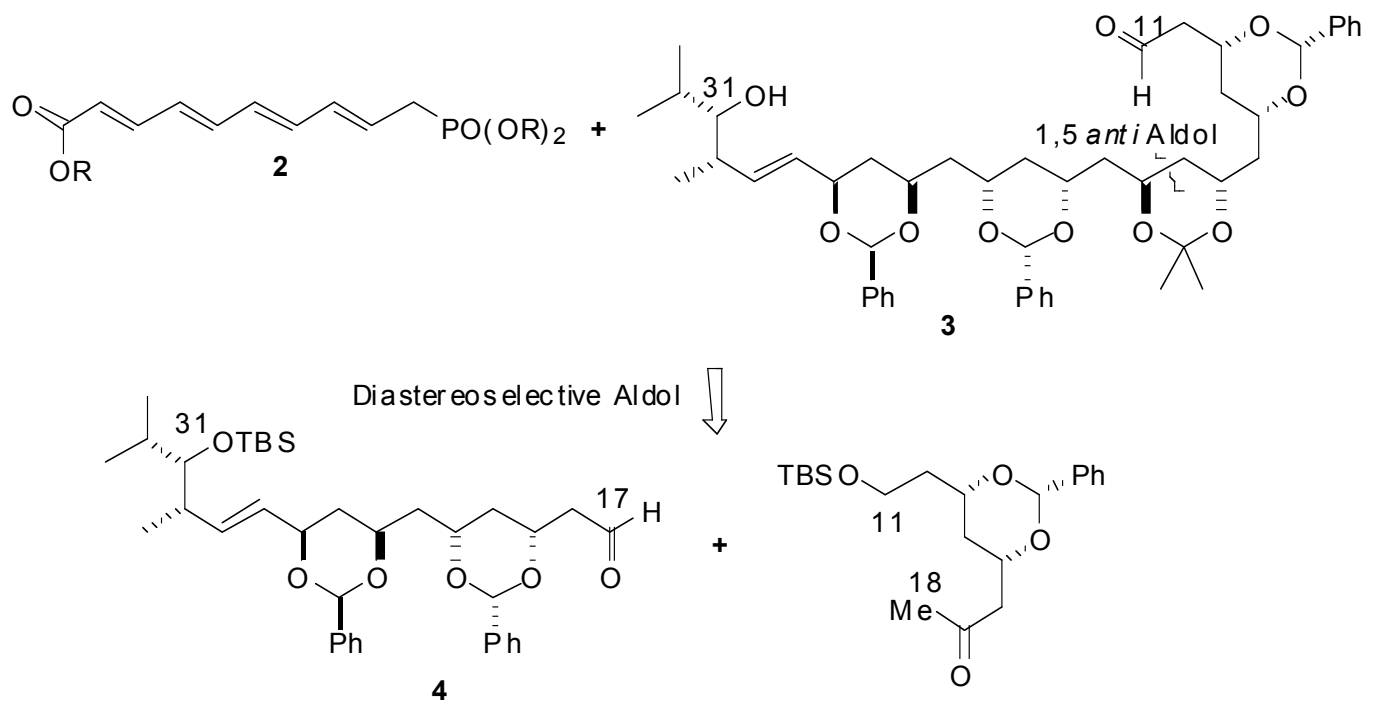

2 Asy mm etr ic Allylation

2 Diaster eoselective Hydration

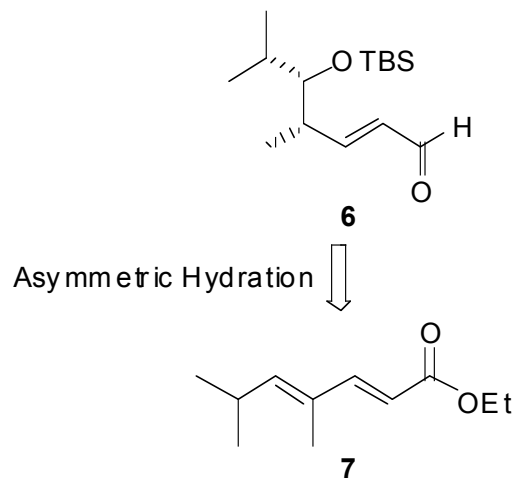

5

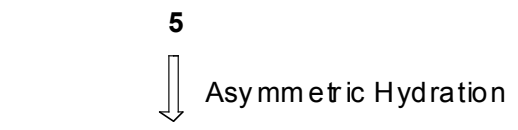

OTBS

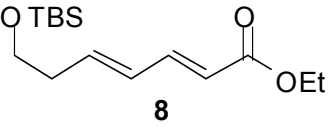

In addition to developing new reaction sequences for the practical syntheses of biologically important molecules, the O'Doherty group has also been interested in 
developing a de novo asymmetric approach to stereochemically complex chiral molecules by using an asymmetric catalysis to install all the chiral centers from achiral starting materials (i.e., 7 and $\mathbf{8}$, Scheme 15). If the two Leighton allylation reactions in the O'Doherty route could be replaced with catalytic asymmetric allylation reactions, then this route to RK-397 would become truly a de novo asymmetric approach. Thus, we decided to try to incorporate the newly developed Krische asymmetric allylation as an alternative to the two Leighton allylation reactions. At the outset, it was decided this reaction would be conducted in collaboration with the Krische group.

Scheme 16: Synthesis of Leighton Allylation Intermediates Towards RK-397

a)

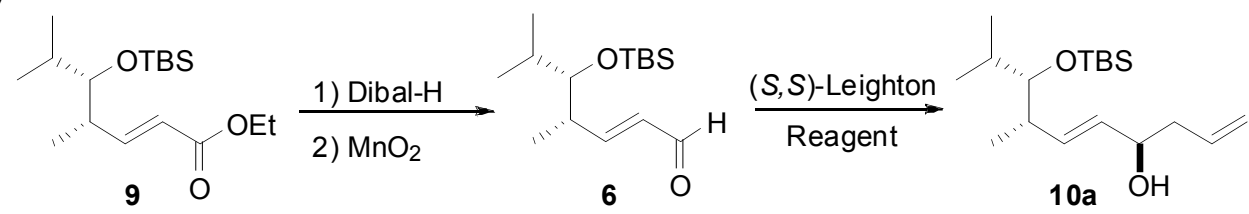

b)

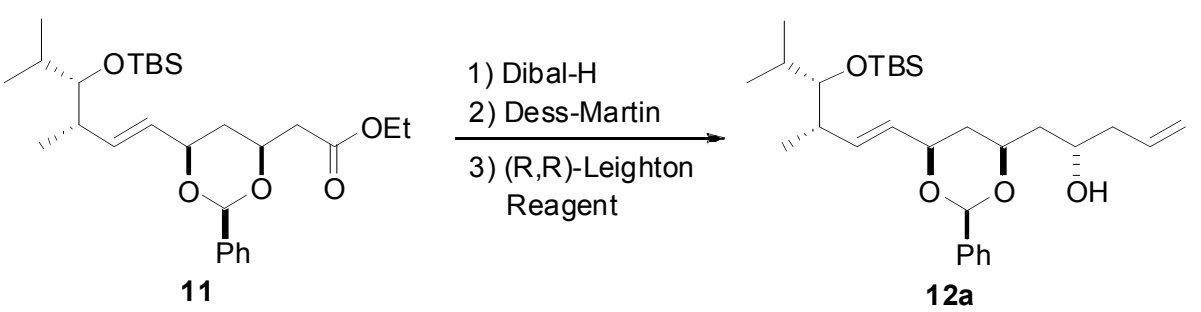

Outlined in Scheme 16 are the two key sequences (a and $\mathbf{b})$ that contain the relevant Leighton allylation steps. In addition, to having the advantage of replacing stoichiometric reagents with catalytic reagents, the incorporation of two Krische allylation reactions will eliminate the need for two additional oxidation reactions. 


\subsection{Outline of Krische Catalytic Asymmetric Allylation}

Krische and coworkers have developed a transfer hydrogenation/allylation reaction that employs an iridium catalyst generated in situ to couple allyl acetate to allylic, aliphatic, and benzylic alcohols to furnish homoallylic alcohol products with high levels of asymmetric induction (Scheme 17). ${ }^{22}$

Scheme 17: Ir-Catalyzed Transfer Hydrogenative Allylation of Allylic Alcohols

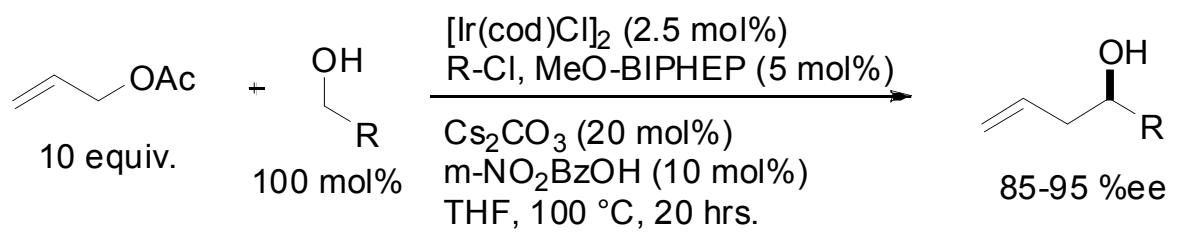

The Ir-catalyzed transfer hydrogenative allylation of alcohols shown above is very important in the synthesis of a wide range of diverse natural product architectures. By using this type of catalytic asymmetric allylation reaction, one is able to eliminate the stoichiometric amount of metallic waste that is associated with other types of asymmetric allylations and oxidation/reductions steps that may occur in a total synthesis. In addition, by eliminating the use of an oxidation steps it also reduces the amount of waste generated. Thus the Krische allylation could be a very valuable tool towards the total or formal synthesis of a natural product. 


\subsection{Synthesized Intermediates for Krische Allylation and Future Work}

A series of alcohol intermediates, aldehyde standards and homoallylic alcohol products were synthesized in preparation for the Krische collaboration (scheme 18 and 19). The two homoallylic alcohols $\mathbf{1 3}$ and $\mathbf{1 4}$ were prepared from Dibal-H reduction of the known esters $\mathbf{9}$ and $\mathbf{1 1}$ (Scheme 18). Samples of $300 \mathrm{mg}$ of $\mathbf{1 3}$ and $150 \mathrm{mg}$ of $\mathbf{1 4}$ were prepared and sent to the Krische labs at the University of Texas-Austin.

Scheme 18: Synthesized Alcohols

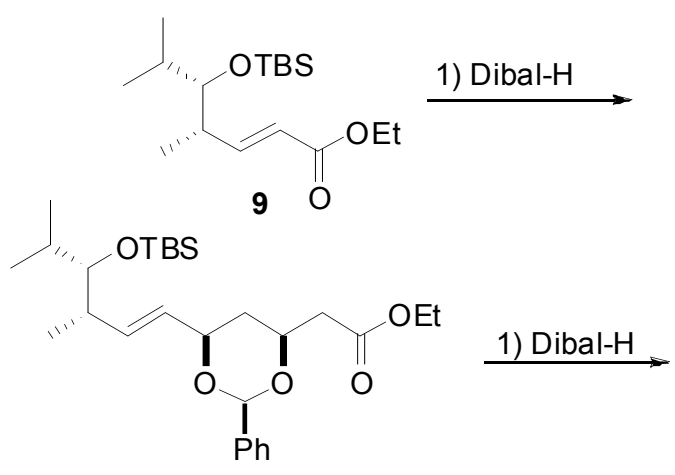

11

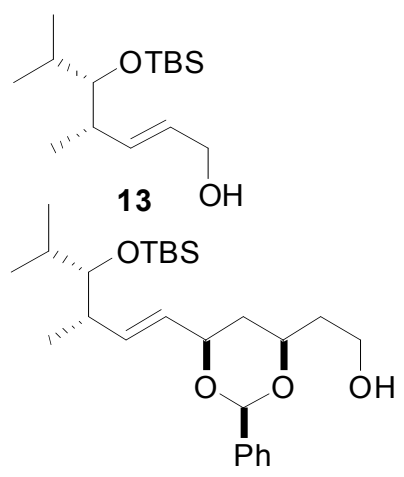

14

Scheme 19: Synthesized Aldehydes<smiles>CC(C)O[13C](=[18O])/C=C/CO</smiles>

13

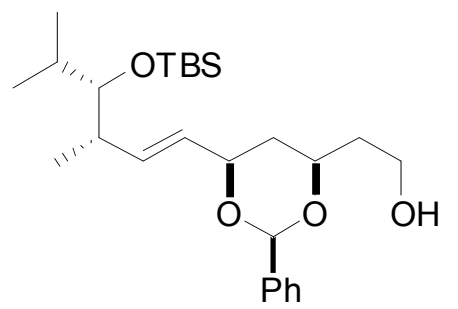

14

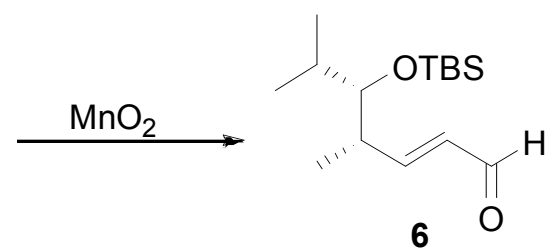

Dess-Martin<smiles>CC(C)[C@@H](O[SbH3])[C@@H](C)/C=C/C1CC(CC=O)O[C@H](Pc2ccccc2)O1</smiles> 
Because the Krische allylation reaction generates aldehyde intermediate, the two aldehydes 6 and 15 were prepared by $\mathrm{MnO}_{2}$ and Dess-Martin oxidation respectively (scheme 19). Finally, the two aldehydes were asymmetrically allylated to prepare samples of the two sets of two diastereomeric homoallylic alcohols 10a and 10b as well as 12a and 12b using the enantiomeric Leighton reagents (Scheme 20). Thus samples of $10 \mathrm{mg}$ of $\mathbf{1 0 a}, 15 \mathrm{mg}$ of $\mathbf{1 0 b}, 10 \mathrm{mg}$ of $\mathbf{1 2 a}$ and $10 \mathrm{mg}$ of $\mathbf{1 2} \mathbf{b}$ were prepared and sent to the Krische labs at the University of Texas-Austin. These efforts are on going and will be reported in due course.

Scheme 20: Leighton Allylation Products

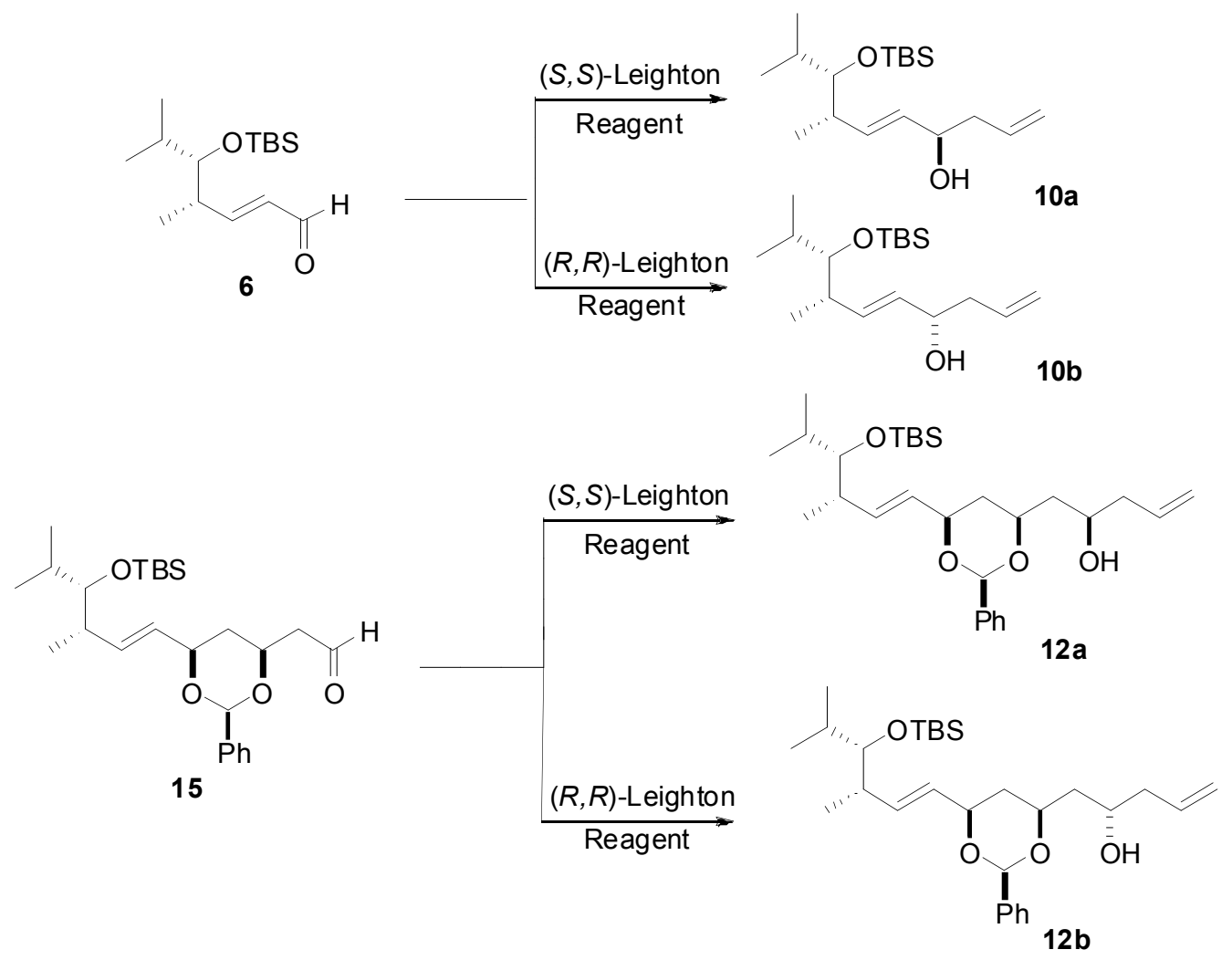




\section{Conclusion:}

In conclusion, a short total synthesis of $(\mathrm{R})-(+)$-Goniothalamin Oxide has been completed using a Leighton asymmetric allylation reaction and a Grubbs ring-closing metathesis. Also intermediate alcohols and aldehydes of RK-397 were synthesized for a collaboration to complete a catalytic asymmetric allylation. 


\section{CHAPTER III}

\section{Experimental Section}

\subsection{General Information: Instrumentation, Materials, Manipulation}

${ }^{1} \mathrm{H}$ and ${ }^{13} \mathrm{C}$ NMR spectra were recorded on a 600 or $270 \mathrm{MHz}$ spectrometer. Chemical shifts are reported relative to internal tetramethylsilane $(\delta 0.00 \mathrm{ppm})$ or $\mathrm{CDCl}_{3}(\delta 7.26$ ppm) or $\mathrm{CD}_{3} \mathrm{OD}(\delta 4.89 \mathrm{ppm})$ for ${ }^{1} \mathrm{H} \mathrm{NMR}$ and $\mathrm{CDCl}_{3}(\delta 77.1 \mathrm{ppm})$ or $\mathrm{CD}_{3} \mathrm{OD}(\delta 49.15$ ppm) for ${ }^{13} \mathrm{C}$ NMR. Infrared (IR) spectra were obtained on a FT-IR spectrometer. Optical rotations were measured with a digital polarimeter in the solvent specified. Melting points were determined with a standard melting point apparatus and are uncorrected. Flash column chromatography was performed on 60-200 mesh silica gel. Analytical thin-layer chromatography was performed with precoated glass-backed plates and visualized by quenching of fluorescence and by charring after treatment with $p$ anisaldehyde or phosphomolybdic acid (PMA) or potassium permanganate stain $\left(\mathrm{KMnO}_{4}\right) . \quad R_{f}$ values are obtained by elution in the stated solvent ratios $(\mathrm{v} / \mathrm{v})$. Ether, THF, methylene chloride and triethylamine were dried by passing through activated alumina column with argon gas pressure. Commercial reagents were used without purification unless otherwise noted. Air and/ or moisture- sensitive reactions were carried out under an atmosphere of argon/nitrogen using oven-dried glassware and standard syringe/septa techniques. HPLC analyses were carried out using a chiral column eluting (flow rate $=1.0 \mathrm{~mL} / \mathrm{min}$ ) with Argon-degassed HPLC grade solvents. Detection was done by UV. 


\section{(3R,E)-1-Phenylhexa-1,5-dien-3-ol (2):}

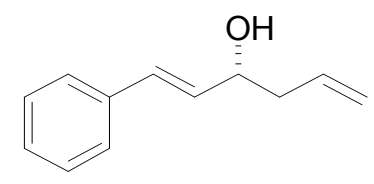

To a solution of $E$-cinnamaldehyde 1 (478 $\mathrm{mg}, 3.62 \mathrm{mmol}$ ) in $5 \mathrm{~mL}$ of $\mathrm{CH}_{2} \mathrm{Cl}_{2}$ at $-10{ }^{\circ} \mathrm{C}$ was added (S,S)-Leighton Reagent $(1.0 \mathrm{~g}, 1.81 \mathrm{mmol})$ in $4 \mathrm{~mL}$ of $\mathrm{CH}_{2} \mathrm{Cl}_{2}$ at $-10{ }^{\circ} \mathrm{C}$. After stirring for $5 \mathrm{~min}$ the solution was stored in a freezer for $20 \mathrm{hrs}$. The reaction was quenched with $1 \mathrm{~N} \mathrm{HCl}(10 \%)$, sat. $\mathrm{NH}_{4} \mathrm{Cl}$ aqueous solution, and then diluted with EtOAc then passed through celite. The aqueous layer was extracted with EtOAc and the combined organic layers were washed with brine, dried over anhydrous $\mathrm{Na}_{2} \mathrm{SO}_{4}$, and concentrated to afford the crude product. Flash chromatography on silica gel $(8: 2(\mathrm{v} / \mathrm{v})$ hexane/EtOAc) provided compound 2 (600 mg, 95\% yield) as a yellow oil. $\mathrm{R}_{f}=0.37$ $\left(8: 2(\mathrm{v} / \mathrm{v})\right.$ hexane/EtOAc). Spectral data gave a satisfactory match to previous reports. ${ }^{23}$ $[\alpha]^{25}=30^{\circ}\left(c 1.6, \mathrm{CHCl}_{3}\right) ;$ IR (neat, $\left.\mathrm{cm}^{-1}\right) 3348,1640,1493,964,913,746,691 ;{ }^{1} \mathrm{H}$ NMR $\left(\mathrm{CDCl}_{3}, 600 \mathrm{MHz}\right) 7.39(\mathrm{~m}, 2 \mathrm{H}), 7.32(\mathrm{~m}, 2 \mathrm{H}), 7.24(\mathrm{~m}, 1 \mathrm{H}), 6.62(\mathrm{~d}, J=15.6 \mathrm{~Hz}$, 1H), $6.18(\mathrm{dd}, J=15.6,6.6 \mathrm{~Hz}, 1 \mathrm{H}), 5.87$ (ddd, $J=17.4,10.2,7.2,7.2 \mathrm{~Hz}, 1 \mathrm{H}), 5.19$ $(\mathrm{m}, 2 \mathrm{H}), 4.37(\mathrm{dd}, 6.6,6.6 \mathrm{~Hz}, 1 \mathrm{H}), 2.42(\mathrm{~m}, 2 \mathrm{H}), 1.85(\mathrm{~s}, 1 \mathrm{H}) ;{ }^{13} \mathrm{C} \mathrm{NMR}\left(\mathrm{CDCl}_{3}, 600\right.$ MHz) $\delta 136.6,134.0,131.5,130.4,128.5,127.6,126.4,118.5,71.7,42.0 ;$ HRMS (CI) calcd for $\left[\mathrm{C}_{12} \mathrm{H}_{14} \mathrm{O}+\mathrm{Na}\right]^{+}: 197.0945$, Found: 197.0942 


\section{(1R,2'S,3'S)-3'-phenyloxiran-2'-yl)but-3-en-1-ol (3a):}

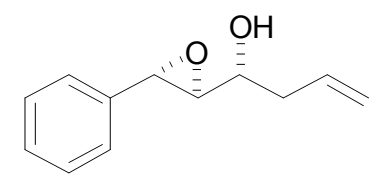

To a solution of product (1R,E)-1-phenylhexa-1,5-dien-3-ol $2(150 \mathrm{mg}, 0.861 \mathrm{mmol})$ in 7 $\mathrm{mL}$ of benzene was added $\mathrm{VO}(\mathrm{acac})_{2}(3 \mathrm{mg}, 12 \mu \mathrm{mol})$ to produce a green colored solution. After $10 \mathrm{~min}$ of stirring $t$-BuOOH ( $85 \mathrm{mg}, 0.947 \mathrm{mmol})$ was added to the solution which was accompanied by a color change to a pale yellow/orange color. The reaction was quenched with a sat. $\mathrm{NaHCO}_{3}$ aqueous solution. The layers were separated. The aqueous layer was extracted with EtOAc and the combined organic layers were washed with brine, dried over anhydrous $\mathrm{Na}_{2} \mathrm{SO}_{4}$, and concentrated to afford crude product. Flash chromatography on silica gel (9:1 (v/v) hexane/EtOAc) provided compound 3a (119 mg, 71\% yield) as a colorless oil. Spectral data gave a satisfactory match to previous reports. ${ }^{24} \mathrm{R}_{f}=0.30(8: 2(\mathrm{v} / \mathrm{v})$ hexanes:EtOAc $) ;[\alpha]^{25}{ }_{\mathrm{D}}=26^{\circ}(c 0.4$, $\mathrm{CHCl}_{3}$ ); IR (neat, $\left.\mathrm{cm}^{-1}\right)$ 3439, 1642, 917; ${ }^{1} \mathrm{H}$ NMR $\left(\mathrm{CDCl}_{3}, 270 \mathrm{MHz}\right) 7.32$ (m, 5H), 5.90 (ddt, $J=16.8,10.2,7.2,7.2 \mathrm{~Hz}, 1 \mathrm{H}), 5.17(\mathrm{~m}, 2 \mathrm{H}), 3.99$ (dddd, $J=4.8,4.8,4.0,4.0 \mathrm{~Hz}$, $1 \mathrm{H}), 3.97(\mathrm{~d}, J=1.8 \mathrm{~Hz}, 1 \mathrm{H}), 3.10(\mathrm{dd}, J=3.0,1.8 \mathrm{~Hz}, 1 \mathrm{H}), 2.35(\mathrm{~m}, 2 \mathrm{H}), 2.03(\mathrm{~m}, 1 \mathrm{H})$;

${ }^{13} \mathrm{C} \mathrm{NMR}\left(\mathrm{CDCl}_{3}, 600 \mathrm{MHz}\right) \delta 136.8,133.4,128.5,128.3,125.7,118.4,68.3,64.2,55.0$, 37.9; HRMS (CI) calcd for $\left[\mathrm{C}_{12} \mathrm{H}_{14} \mathrm{O}_{2}+\mathrm{Na}\right]^{+}: 213.0894$, Found: 213.0892 
(1R,2'S,3'S)-3'-phenyloxiran-2'-yl)but-3-enyl acrylate (4a):

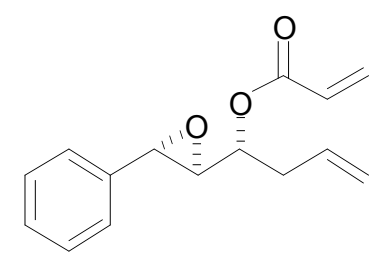

To a solution of product (1R,2'S,3'S)-3'-phenyloxiran-2'-yl)but-3-en-1-ol 3a (120 mg, $0.629 \mathrm{mmol})$ in $10 \mathrm{~mL}$ of $\mathrm{CH}_{2} \mathrm{Cl}_{2}$ was added acyrilic acid (188 mg, $\left.2.61 \mathrm{mmol}\right), \mathrm{DCC}$ (538 mg, $2.61 \mathrm{mmol}$ ), and DMAP (4 mg) at room temperature. After stirring for $6 \mathrm{hrs}$ the reaction was diluted with ether, passed through celite, and extracted with $1 \mathrm{M}$ aqueous $\mathrm{NaHSO}_{4}$ and then sat. aqueous $\mathrm{NaHCO}_{3}$. The combined organic layers were washed with brine, dried over anhydrous $\mathrm{Na}_{2} \mathrm{SO}_{4}$, and concentrated. Flash chromatography on silica gel (9.5:0.5 (v/v) hexanes/EtOAc) provided compound $4 \mathbf{a}(92.2 \mathrm{mg}, 60 \%$ yield) as a colorless oil. $\mathrm{R}_{f}=0.59\left(8: 2(\mathrm{v} / \mathrm{v})\right.$ hexanes:EtOAc); $[\alpha]^{25}=61^{\circ}\left(c 0.4, \mathrm{CHCl}_{3}\right)$; IR (neat, $\left.\mathrm{cm}^{-1}\right)$ 1731, 1240, 1186, 1046; ${ }^{1} \mathrm{H} \mathrm{NMR}\left(\mathrm{CDCl}_{3}, 600 \mathrm{MHz}\right) 7.30(\mathrm{~m}, 5 \mathrm{H}), 6.43$ (dd, $J=17.3,1.5 \mathrm{~Hz}, 1 \mathrm{H}), 6.12(\mathrm{dd}, J=17.1,10.4 \mathrm{~Hz}, 1 \mathrm{H}), 5.84(\mathrm{~m}, 2 \mathrm{H}), 5.16(\mathrm{~m}, 2 \mathrm{H}), 4.99$ (ddd, $J=7.2,5.2,3.2 \mathrm{~Hz}), 3.94(\mathrm{~d}, J=2.0 \mathrm{~Hz}, 1 \mathrm{H}), 3.07(\mathrm{dd}, J=5.7,2.0 \mathrm{~Hz}, 1 \mathrm{H}), 2.57$ $(\mathrm{m}, 2 \mathrm{H}) ;{ }^{13} \mathrm{C} \mathrm{NMR}\left(\mathrm{CDCl}_{3}, 600 \mathrm{MHz}\right) \delta 165.3,136.6,132.4,131.3,128.5,128.3,128.1$, 125.6, 118.5, 72.1, 61.8, 57.3, 35.8 HRMS (CI) calcd for $\left[\mathrm{C}_{12} \mathrm{H}_{14} \mathrm{O}_{2}+\mathrm{Na}\right]^{+}:$267.0999, Found: 267.0997 


\section{(R)-(+)-goniothalamin oxide (5):}

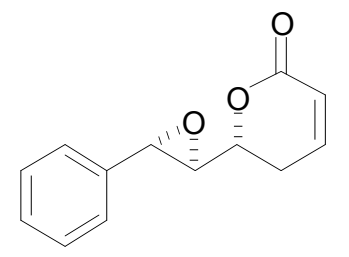

To a solution of product (1R,2'S,3'S)-3'-phenyloxiran-2'-yl)but-3-enyl acrylate 4a (25 $\mathrm{mg}, 0.10 \mathrm{mmol}$ ) in $7 \mathrm{~mL}$ of $\mathrm{CH}_{2} \mathrm{Cl}_{2}$ was added Grubbs (I) catalyst ( $8 \mathrm{mg}, 0.010 \mathrm{mmol}$ ) at room temperature. After stirring for $4 \mathrm{hrs}$ at reflux the reaction was concentrated. Flash chromatography on silica gel $(7: 3(\mathrm{v} / \mathrm{v})$ hexane:EtOAc) provided compound $5(17 \mathrm{mg}$, $77 \%$ yield) as a dark oil. (Note: Color caused by Grubbs catalyst) $\mathrm{R}_{f}=0.086(8: 2(\mathrm{v} / \mathrm{v})$ hexanes:EtOAc). Spectral data gave a satisfactory match to previous reports. ${ }^{25}[\alpha]^{25}$ $=100^{\circ}\left(c 0.4, \mathrm{CHCl}_{3}\right)$; IR (neat, $\left.\mathrm{cm}^{-1}\right) 1724,1247,1041,815 ;{ }^{1} \mathrm{H} \mathrm{NMR}\left(\mathrm{CDCl}_{3}, 600\right.$ MHz) 7.34(m, 5H), $6.94(\mathrm{ddd}, J=8.7,4.9,3.7 \mathrm{~Hz}, 1 \mathrm{H}), 6.08(\mathrm{ddd}, J=9.6,3.7,1.7,1 \mathrm{H})$, 4.45 (ddd, $J=9.1,5.8,5.8 \mathrm{~Hz}, 1 \mathrm{H}), 3.89$ (d, $J=1.9 \mathrm{~Hz}, 1 \mathrm{H}), 3.27$ (dd, $J=5.6,1.9 \mathrm{~Hz}$, 1H), $2.59(\mathrm{~m}, 2 \mathrm{H}) ;{ }^{13} \mathrm{C} \mathrm{NMR}\left(\mathrm{CDCl}_{3}, 600 \mathrm{MHz}\right) \delta 163.7,144.2,135.7,128.7,128.6$, 125.7, 121.6, 77.1, 61.5, 57.3, 25.9 HRMS (CI) calcd for $\left[\mathrm{C}_{12} \mathrm{H}_{14} \mathrm{O}_{2}+\mathrm{Na}\right]^{+}: 217.0786$ Found: 217.0865 


\section{$\left(1 R, 2^{\prime} R, 3 ' R\right)-3^{\prime}$-phenyloxiran-2'-yl)but-3-enyl acrylate (4b):}

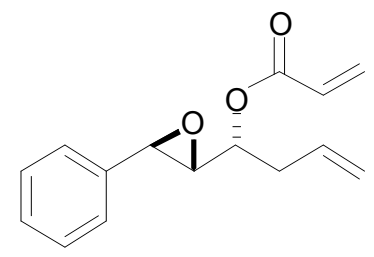

To a solution of product (1R,2'R,3'R)-3' -phenyloxiran-2' -yl)but-3-en-1-ol 3b (120 mg, $0.629 \mathrm{mmol})$ in $10 \mathrm{~mL}$ of $\mathrm{CH}_{2} \mathrm{Cl}_{2}$ was added acyrilic acid (188 mg, $\left.2.61 \mathrm{mmol}\right)$, DCC (538 mg, $2.61 \mathrm{mmol}$ ), and DMAP (4 mg) at room temperature. After stirring for $6 \mathrm{hrs}$ the reaction was diluted with ether, passed through celite, and extracted with $1 \mathrm{M}$ aqueous $\mathrm{NaHSO}_{4}$ and then sat. aqueous $\mathrm{NaHCO}_{3}$. The combined organic layers were washed with brine, dried over anhydrous $\mathrm{Na}_{2} \mathrm{SO}_{4}$, and concentrated. Flash chromatography on silica gel (9.5:0.5 (v/v) hexanes/EtOAc) provided compound $\mathbf{4 b}(92.2 \mathrm{mg}, 60 \%$ yield) as a colorless oil. $\mathrm{R}_{f}=0.58\left(8: 2(\mathrm{v} / \mathrm{v})\right.$ hexanes:EtOAc); IR (neat, $\left.\mathrm{cm}^{-1}\right) 1731,1406,1373$, 1240, 1186, 1046, 984; ${ }^{1} \mathrm{H}$ NMR $\left(\mathrm{CDCl}_{3}, 270 \mathrm{MHz}\right) 7.29(\mathrm{~m}, 5 \mathrm{H}), 6.48(\mathrm{dd}, J=17.3,1.5$ Hz, 1H), $6.17(\mathrm{dd}, J=17.0,7.0 \mathrm{~Hz}, 1 \mathrm{H}), 5.83(\mathrm{~m}, 2 \mathrm{H}), 5.14(\mathrm{~m}, 1 \mathrm{H}), 4.98(\mathrm{dd}, J=12.6$, 6.7, 1H), $3.79(\mathrm{~d}, J=2.0 \mathrm{~Hz}, 1 \mathrm{H}), 3.17(\mathrm{dd}, J=5.9,2.0 \mathrm{~Hz}, 1 \mathrm{H}), 2.54(\mathrm{~m}, 2 \mathrm{H}) ;{ }^{13} \mathrm{C}$ NMR $\left(\mathrm{CDCl}_{3}, 600 \mathrm{MHz}\right) \delta 165.6,136.5,132.4,131.6,128.7,128.6,128.4,125.8,119.1,73.1$ $62.7,56.7,36.2$ 


\section{(R)-6-((2R,3R)-3-phenyloxiran-2-yl)-5,6-dihydro-2H-pyran-2-one (6):}

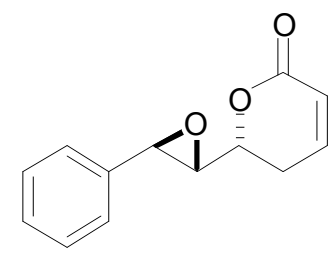

To a solution of product (1R,2'R,3'R)-3'-phenyloxiran-2'-yl)but-3-enyl acrylate $\mathbf{4 b}$ (25 $\mathrm{mg}, 0.10 \mathrm{mmol})$ in $7 \mathrm{~mL}$ of $\mathrm{CH}_{2} \mathrm{Cl}_{2}$ was added Grubbs (I) catalyst (8 $\left.\mathrm{mg}, 0.010 \mathrm{mmol}\right)$ at room temperature. After stirring for $4 \mathrm{hrs}$ at reflux the reaction was concentrated. Flash chromatography on silica gel (7:3 (v/v) hexane:EtOAc) provided compound 6 (17 mg, $77 \%$ yield) as a dark oil. $\mathrm{R}_{f}=0.087\left(8: 2(\mathrm{v} / \mathrm{v})\right.$ hexanes:EtOAc); IR (neat, $\left.\mathrm{cm}^{-1}\right) 1724$, 1386, 1247, 1041, 815, 698; ${ }^{1} \mathrm{H}$ NMR $\left(\mathrm{CDCl}_{3}, 270 \mathrm{MHz}\right) 7.33(\mathrm{~m}, 5 \mathrm{H}), 6.92$ (ddd, $J=$ 8.7, 5.4, 3.0 Hz, 1H), 6.08 (ddd, 9.9, 2.6, 1.7 1H), 4.68 (ddd, $J=8.7,4.7,3.7 \mathrm{~Hz}, 1 \mathrm{H})$, $4.08(\mathrm{~d}, J=1.9 \mathrm{~Hz}, 1 \mathrm{H}), 3.24(\mathrm{dd}, J=3.7,1.9 \mathrm{~Hz}, 1 \mathrm{H}), 2.62(\mathrm{~m}, 2 \mathrm{H}) ;{ }^{13} \mathrm{C} \mathrm{NMR}\left(\mathrm{CDCl}_{3}\right.$, $600 \mathrm{MHz}) \delta 162.8,143.9,135.9,128.6,128.6,125.7,121.6,75.1,62.1,55.0,26.2$ 
(-)-(E,4S,5S)-Ethyl 5-(tert-butyldimethylsilyloxy)-4,6-dimethylhept-2-enoate (9):

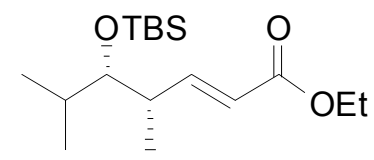

The $\delta$-hydroxy enoate $(200 \mathrm{mg}, 1.0 \mathrm{mmol})$ was added to a flask with $\mathrm{CH}_{2} \mathrm{Cl}_{2}(1.0 \mathrm{~mL})$ followed by addition of 2,6-lutidine $(233 \mu \mathrm{L}, 2.0 \mathrm{mmol})$. The mixture was allowed to cool to $0^{\circ} \mathrm{C}$ in an ice bath. Then TBSOTF $(253 \mu \mathrm{L}, 1.1 \mathrm{mmol})$ was added slowly via syringe and the reaction was allowed to warm to RT and stir 2 hours. The reaction was then quenched with the addition of $\mathrm{Et}_{2} \mathrm{O}(4 \mathrm{~mL})$ followed by washing with a saturated aqueous solution of $\mathrm{CuSO}_{4}(1 \mathrm{~mL})$. The layers were separated and the organic layer was washed with brine $(1.5 \mathrm{~mL})$. The organics were then dried over $\mathrm{Na}_{2} \mathrm{SO}_{4}$ and concentrated en vacuo. The crude mixture was purified immediately by flash column chromatography over silica gel (5\% $\mathrm{CH}_{2} \mathrm{Cl}_{2} / 5 \% \mathrm{Et}_{2} \mathrm{O} /$ Hexanes) to yield TBS-protected enoate 9 (276 mg, $88 \%$ ) as a clear, colorless oil. Spectral data gave a satisfactory match to previous reports. ${ }^{26}[\alpha]^{25}=-27\left(c=1.5, \mathrm{CH}_{2} \mathrm{Cl}_{2}\right) ;{ }^{1} \mathrm{H} \mathrm{NMR}\left(\mathrm{CDCl}_{3}, 270 \mathrm{MHz}\right) \delta 6.97(\mathrm{dd}, J=$ 15.8, $7.9 \mathrm{~Hz}, 1 \mathrm{H}), 5.76(\mathrm{~d}, J=15.8 \mathrm{~Hz}, 1 \mathrm{H}), 4.18(\mathrm{q}, J=7.2 \mathrm{~Hz}, 2 \mathrm{H}), 3.37$ (dd, $J=4.9$, $4.9 \mathrm{~Hz}, 1 \mathrm{H}), 2.51(\mathrm{~m}, 1 \mathrm{H}), 1.71(\mathrm{~m}, 1 \mathrm{H}), 1.25(\mathrm{t}, J=7.2 \mathrm{~Hz}, 3 \mathrm{H}), 1.03(\mathrm{~d}, J=6.9 \mathrm{~Hz}$, 3H), $0.90(\mathrm{~s}, 9 \mathrm{H}), 0.87(\mathrm{~d}, J=6.7 \mathrm{~Hz}, 3 \mathrm{H}), 0.85(\mathrm{~d}, J=6.7 \mathrm{~Hz}, 3 \mathrm{H}), 0.04(\mathrm{~s}, 3 \mathrm{H}), 0.03$ (s, 3H). HRMS (ESI) calcd for $\left[\mathrm{C}_{171} \mathrm{H}_{34} \mathrm{O}_{3} \mathrm{Si}+\mathrm{Na}\right]^{+}: 337.2175$ Found: 337.2180 . 
(-)-(E,4S,5S)-5-(tert-butyldimethylsilyloxy)-4,6-dimethylhept-2-en-1-ol (13):

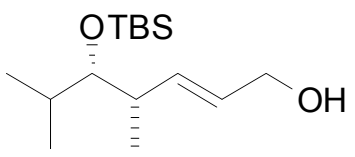

The ester 9 (2.13 g, $6.78 \mathrm{mmol})$ was dissolved in THF $(6.8 \mathrm{ml})$ and cooled to $-78{ }^{\circ} \mathrm{C}$. Next was added 2.2 equiv Dibal-H (14.91 $\mathrm{ml}$ of $1 \mathrm{M}$ hexane solution) via syringe. The reaction was allowed to stir at $-78{ }^{\circ} \mathrm{C}$ for 35 min when determined complete by TLC (UV, anisaldehyde stain). The reaction was then quenched by the addition of acetone (3 $\mathrm{ml}$ ) which was pre-cooled to match the temp of the reaction. The reaction was allowed to stir for $5 \mathrm{~min}$ then warmed to room temp at which time aqueous $20 \mathrm{wt} \% \mathrm{Na}$, K-tartrate $(30 \mathrm{ml})$ was added with rapid stirring. This two phase solution was allowed to stir rapidly until the phases separated easily upon stopping the stirring. The layers were separated and the aqueous layer was extracted with $\mathrm{Et}_{2} \mathrm{O}(3 \times 15 \mathrm{ml})$. The organics were collected and washed with $15 \mathrm{ml}$ of brine and dried over $\mathrm{Na}_{2} \mathrm{SO}_{4}$ followed by concentration en vacuo. This procedure required no further purification and produced allylic alcohol $13(1.623 \mathrm{~g}, 89 \%)$ as a clear, colorless oil. Spectral data gave a satisfactory match to previous reports. ${ }^{27}{ }^{1} \mathrm{H} \mathrm{NMR}\left(\mathrm{CDCl}_{3}, 270 \mathrm{MHz}\right) \delta 5.64(\mathrm{~m}, 2 \mathrm{H})$, $4.10(\mathrm{dd}, J=5.4,5.4 \mathrm{~Hz}, 2 \mathrm{H}), 3.27(\mathrm{dd}, J=5.4,4.3 \mathrm{~Hz}, 1 \mathrm{H}), 2.36(\mathrm{~m}, 1 \mathrm{H}), 1.73(\mathrm{~m}, 1 \mathrm{H})$, $1.24(\mathrm{dd}, J=5.7,5.7 \mathrm{~Hz}, \mathrm{OH}, 1 \mathrm{H}), 0.99(\mathrm{~d}, J=6.9 \mathrm{~Hz}, 3 \mathrm{H}), 0.90(\mathrm{~s}, 9 \mathrm{H}), 0.87$ (d, $J=6.7$ $\mathrm{Hz}, 3 \mathrm{H}), 0.86(\mathrm{~d}, J=6.7 \mathrm{~Hz}, 3 \mathrm{H}), 0.03(\mathrm{~s}, 3 \mathrm{H}), 0.02(\mathrm{~s}, 3 \mathrm{H}) .[\alpha]_{\mathrm{D}}{ }^{24}=-13.5(c=2.6$, $\left.\mathrm{CH}_{2} \mathrm{Cl}_{2}\right)$ 
(-)-(E,4S,5S)-5-(tert-butyldimethylsilyloxy)-4,6-dimethylhept-2-enal (6):

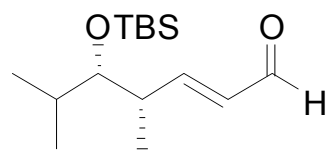

The allylic alcohol $13(1.33 \mathrm{~g}, 4.89)$ was dissolved in $\mathrm{CH}_{2} \mathrm{Cl}_{2}(15 \mathrm{ml})$ followed by the addition of 10 mass equivalent of $\mathrm{MnO}_{2}(13.3 \mathrm{~g})$ in one portion. The reaction was allowed to stir at RT for 4 days until determined complete by TLC (UV, $\left.\mathrm{KMnO}_{4}\right)$. The mixture was filtered through celite and concentrated en vacuo. This procedure required no further purification and produced enal $6(987 \mathrm{mg}, 87.5 \%)$ as a clear, colorless oil. Spectral data gave a satisfactory match to previous reports. ${ }^{28}{ }^{1} \mathrm{H} \mathrm{NMR}\left(\mathrm{CDCl}_{3}, 270 \mathrm{MHz}\right)$ $\delta 9.53(\mathrm{dd}, J=7.9 \mathrm{~Hz}, 1 \mathrm{H}), 6.92(\mathrm{dd}, J=15.8,7.9 \mathrm{~Hz}, 1 \mathrm{H}), 6.13(\mathrm{~d}, J=15.8,8.1 \mathrm{~Hz}$, $1 \mathrm{H}), 3.45(\mathrm{dd}, J=4.9,4.9 \mathrm{~Hz}, 1 \mathrm{H}), 2.64(\mathrm{~m}, 1 \mathrm{H}), 1.73(\mathrm{~m}, 1 \mathrm{H}), 1.08(\mathrm{~d}, J=6.9 \mathrm{~Hz}, 3 \mathrm{H})$, $0.91(\mathrm{~s}, 9 \mathrm{H}), 0.89(\mathrm{~d}, J=6.7 \mathrm{~Hz}, 3 \mathrm{H}), 0.82(\mathrm{~d}, J=6.7 \mathrm{~Hz}, 3 \mathrm{H}), 0.09(\mathrm{~s}, 3 \mathrm{H}), 0.04(\mathrm{~s}, 3 \mathrm{H})$. $[\alpha]_{\mathrm{D}}^{24}=-48.4\left(c=1.2, \mathrm{CH}_{2} \mathrm{Cl}_{2}\right)$. 
(-)-(E,4R,7S,8S)-8-(tert-butyldimethylsilyloxy)-7,9-dimethyldeca-1,5-dien-4-ol (10a):

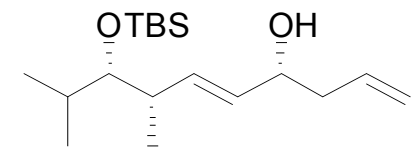

A solution of enal $6(6.00 \mathrm{~g}, 22.2 \mathrm{mmol})$ in $\mathrm{CH}_{2} \mathrm{Cl}_{2}(75 \mathrm{~mL})$ was cooled to $-15^{\circ} \mathrm{C}$ in a salt-ice bath and was added via cannula to a separate RBF containing allyl silane $[(S, S)$ Leighton reagent] $(28.6 \mathrm{~g}, 51.48 \mathrm{mmol})$ in $\mathrm{CH}_{2} \mathrm{Cl}_{2}(75 \mathrm{~mL})$ at $-15^{\circ} \mathrm{C}$. The reaction was then placed in the freezer and allowed to react for 5 days. The reaction mixture was then diluted with EtOAc $(100 \mathrm{~mL})$ and filtered through a plug of Celite to remove the white precipitate that had formed after several minutes stirring with EtOAc. The filtrate was then washed with sat. aq. $\mathrm{NaHCO}_{3}(75 \mathrm{~mL})$ and brine $(75 \mathrm{~mL})$. The organics were then dried over $\mathrm{Na}_{2} \mathrm{SO}_{4}$. After concentration the crude mixture was purified immediately by silica gel column chromatography (5\% EtOAc/Hexanes) to yield $5.80 \mathrm{~g}(84 \%)$ of acetonide 10a. The minor isomer (from the ca $10 \%$ enantiomer) was isolated in a mixture with other products. Spectral data gave a satisfactory match to previous reports. ${ }^{29} R_{f}=0.60$ (1:4 EtOAc:Hexanes), $[\alpha]^{25}{ }_{\mathrm{D}}=-13\left(c=0.9, \mathrm{CH}_{2} \mathrm{Cl}_{2}\right)$; IR (neat, $\mathrm{cm}^{-}$ 1) 3345 (br), 2960, 2930, 2856, 1634, 1473, 1260, 1113, 1055, 1005, 975, 856, 775; ${ }^{1} \mathrm{H}$ $\operatorname{NMR}\left(\mathrm{CDCl}_{3}, 600 \mathrm{MHz}\right) \delta 5.79(\mathrm{~m}, 1 \mathrm{H}), 5.62(\mathrm{dd}, J=15.0,7.8 \mathrm{~Hz}, 1 \mathrm{H}), 5.44(\mathrm{dd}, J=$ 15.0, 7.2 Hz, 1H), $5.12(\mathrm{~m}, 2 \mathrm{H}), 4.12(\mathrm{~m}, 1 \mathrm{H}), 3.25(\mathrm{dd}, J=6.0,4.2 \mathrm{~Hz}, 1 \mathrm{H}), 2.30$ (m, $3 \mathrm{H}), 1.73(\mathrm{~m}, 1 \mathrm{H}), 1.56(\mathrm{~d}, J=4.0 \mathrm{~Hz}, 1 \mathrm{H}), 0.98(\mathrm{~d}, J=6.6 \mathrm{~Hz}, 3 \mathrm{H}), 0.89(\mathrm{~s}, 9 \mathrm{H}), 0.87$ $(\mathrm{d}, J=6.7 \mathrm{~Hz}, 3 \mathrm{H}), 0.83(\mathrm{~d}, J=6.7 \mathrm{~Hz}, 3 \mathrm{H}), 0.03(\mathrm{~s}, 6 \mathrm{H}) ;{ }^{13} \mathrm{C} \mathrm{NMR}\left(\mathrm{CDCl}_{3}, 150 \mathrm{MHz}\right)$ $\delta 136.1,134.4,131.1,117.9,80.9,72.2,42.0,41.3,31.5,26.0,20.5,17.4,16.7,-3.5,-3.8$. HRMS (ESI) calcd for $\left[\mathrm{C}_{18} \mathrm{H}_{36} \mathrm{O}_{2} \mathrm{Si}+\mathrm{Na}\right]^{+}: 335.2382$ Found: 335.2385.

(4S,7S,8S,E)-8-(tert-butyldimethylsilyloxy)-7,9-dimethyldeca-1,5-dien-4-ol (10b): 


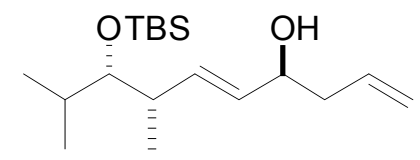

A solution of enal $6(0.07 \mathrm{~g}, 0.259 \mathrm{mmol})$ in $\mathrm{CH}_{2} \mathrm{Cl}_{2}(5 \mathrm{~mL})$ was cooled to $-15^{\circ} \mathrm{C}$ in a salt-ice bath and was added via cannula to a separate RBF containing allyl silane $[(R, R)$ Leighton reagent] $(0.286 \mathrm{~g}, 0.517 \mathrm{mmol})$ in $\mathrm{CH}_{2} \mathrm{Cl}_{2}(5 \mathrm{~mL})$ at $-15^{\circ} \mathrm{C}$. The reaction was then placed in the freezer and allowed to react for 3 days. The reaction mixture was then diluted with EtOAc $(50 \mathrm{~mL})$ and filtered through a plug of Celite to remove the white precipitate that had formed after several minutes stirring with EtOAc. The filtrate was then washed with sat. aq. $\mathrm{NaHCO}_{3}(20 \mathrm{~mL})$ and brine $(25 \mathrm{~mL})$. The organics were then dried over $\mathrm{Na}_{2} \mathrm{SO}_{4}$. After concentration the crude mixture was purified immediately by silica gel column chromatography (5\% EtOAc/Hexanes) to yield $0.080 \mathrm{~g}(86 \%)$ of acetonide 10b. The minor isomer (from the ca 10\% enantiomer) was isolated in a mixture with other products. Spectral data gave a satisfactory match to previous reports. ${ }^{25} R_{f}=0.60$ (1:4 EtOAc:Hexanes), $[\alpha]^{25}{ }_{\mathrm{D}}=-13\left(c=0.9, \mathrm{CH}_{2} \mathrm{Cl}_{2}\right)$; IR (neat, $\mathrm{cm}^{-}$ 1) 3353 (br), 2957, 2929, 2857, 1642, 1472, 1251, 1112, 1050, 1005, 974, 857, 834, 771; ${ }^{1} \mathrm{H}$ NMR $\left(\mathrm{CDCl}_{3}, 600 \mathrm{MHz}\right) \delta 5.80(\mathrm{~m}, 1 \mathrm{H}), 5.62(\mathrm{dd}, J=15.0,7.8 \mathrm{~Hz}, 1 \mathrm{H}), 5.44(\mathrm{dd}, J$ $=15.0,7.2 \mathrm{~Hz}, 1 \mathrm{H}), 5.12(\mathrm{~m}, 2 \mathrm{H}), 4.12(\mathrm{~m}, 1 \mathrm{H}), 3.25(\mathrm{dd}, J=6.0,4.2 \mathrm{~Hz}, 1 \mathrm{H}), 2.30(\mathrm{~m}$, 3H), $1.73(\mathrm{~m}, 1 \mathrm{H}), 1.56$ (d, $J=4.0 \mathrm{~Hz}, 1 \mathrm{H}), 0.98$ (d, $J=6.6 \mathrm{~Hz}, 3 \mathrm{H}), 0.89$ (s, 9H), 0.87 $(\mathrm{d}, J=6.7 \mathrm{~Hz}, 3 \mathrm{H}), 0.83(\mathrm{~d}, J=6.7 \mathrm{~Hz}, 3 \mathrm{H}), 0.03(\mathrm{~s}, 6 \mathrm{H}) ;{ }^{13} \mathrm{C} \mathrm{NMR}\left(\mathrm{CDCl}_{3}, 150 \mathrm{MHz}\right)$ $\delta$ 135.9, 134.3, 130.7, 118.0, 80.7, 71.8, 42.0, 40.7, 31.6, 26.1, 20.5, 18.4, 17.4, 16.4.

\section{(-)-Ethyl 2-((2R,4S,6R)-6-((E,3S,4S)-4-(tert-butyldimethylsilyloxy)-3,5-dimethylhex-} 1-enyl)-2-phenyl-1,3-dioxan-4-yl)acetate (11): 


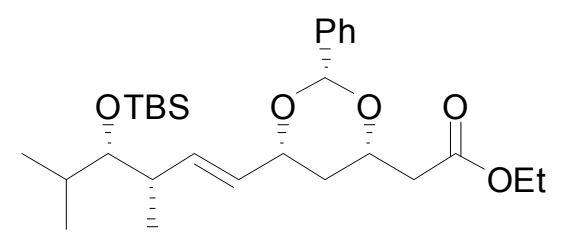

To a solution of the alcohol $(5.2 \mathrm{~g}, 13.5 \mathrm{mmol})$ and benzaldehyde $(1.51 \mathrm{~mL}, 15.0 \mathrm{mmol})$ in THF (42 mL) was added the $t$-BuOK $(151 \mathrm{mg}, 1.35 \mathrm{mmol})$. The reaction mixture was stirred for $15 \mathrm{~min}$. The addition of $t$ - $\mathrm{BuOK}$ and benzaldehyde was repeated for 3 times every $15 \mathrm{~min}$ and then the reaction mixture was quenched with $35 \mathrm{~mL} \mathrm{pH=7}$ buffer solution, extracted with $\mathrm{Et}_{2} \mathrm{O}(3 \times 100 \mathrm{~mL})$, dried $\left(\mathrm{Na}_{2} \mathrm{SO}_{4}\right)$, and concentrated under reduced pressure. The crude product was purified using silica gel flash chromatography eluting with $10 \% \mathrm{EtOAc} / \mathrm{hexane}$ to give $4.23 \mathrm{~g}$ ( $8.64 \mathrm{mmol}, 64 \%)$ of colorless oil acetal 11. $R_{f}=0.70\left(1: 4\right.$ EtOAc:Hexanes), $[\alpha]^{25}{ }_{\mathrm{D}}=-8\left(c=1.0, \mathrm{CH}_{2} \mathrm{Cl}_{2}\right)$; IR (neat, $\left.\mathrm{cm}^{-1}\right) 2957$, $2929,2856,1736,1472,1370,1339,1251,1149,1095,1051,1025,974,938,857,835$, 772, 697; ${ }^{1} \mathrm{H}$ NMR $\left(\mathrm{CDCl}_{3}, 600 \mathrm{MHz}\right) \delta 7.50(\mathrm{~m}, 2 \mathrm{H}), 7.33$ (m, 3H), $5.76(\mathrm{dd}, J=15.0$, $7.8 \mathrm{~Hz}, 1 \mathrm{H}), 5.60(\mathrm{~s}, 1 \mathrm{H}), 5.50(\mathrm{dd}, J=15.0,7.2 \mathrm{~Hz}, 1 \mathrm{H}), 4.34(\mathrm{~m}, 2 \mathrm{H}), 4.17$ (q, $J=7.2$ Hz, 2H), 3.29 (dd, $J=5.4,4.2 \mathrm{~Hz}, 1 \mathrm{H}), 2.73(\mathrm{dd}, J=15.6,7.2 \mathrm{~Hz}, 1 \mathrm{H}), 2.51(\mathrm{dd}, J=$ 15.6, $6.0 \mathrm{~Hz}, 1 \mathrm{H}), 2.34(\mathrm{~m}, 1 \mathrm{H}), 1.75(\mathrm{~m}, 1 \mathrm{H}), 1.74(\mathrm{~m}, 1 \mathrm{H}), 1.56(\mathrm{~m}, 1 \mathrm{H}), 1.26(\mathrm{t}, J=$ $7.2 \mathrm{~Hz}, 3 \mathrm{H}), 1.00(\mathrm{~d}, J=6.6 \mathrm{~Hz}, 3 \mathrm{H}), 0.91(\mathrm{~s}, 9 \mathrm{H}), 0.89$ (d, $J=6.6 \mathrm{~Hz}, 3 \mathrm{H}), 0.85$ (d, $J=$ 6.6 Hz, 3H), $0.04(\mathrm{~s}, 6 \mathrm{H}) ;{ }^{13} \mathrm{C} \mathrm{NMR}\left(\mathrm{CDCl}_{3}, 150 \mathrm{MHz}\right) \delta$ 170.7, 138.4, 136.5, 128.6, $128.2,128.1,126.1,100.6,80.7,77.2,73.1,60.5,41.0,40.7,36.7,31.6,26.1,20.5,18.4$, 17.6, 15.9, 14.1, -3.5, -3.7; HRMS (ESI) calcd for $\left[\mathrm{C}_{28} \mathrm{H}_{46} \mathrm{O}_{5} \mathrm{Si}+\mathrm{Na}\right]^{+}: 513.3006$ Found: 513.2982.

(-)-2-((2R,4S,6R)-6-((E,3S,4S)-4-(tert-butyldimethylsilyloxy)-3,5-dimethylhex-1enyl)-2-phenyl-1,3-dioxan-4-yl)acetaldehyde (15): 


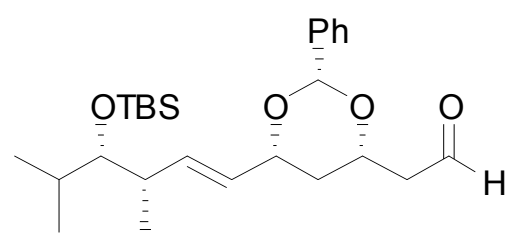

To a solution of alcohol $14(40 \mathrm{mg}, 0.089 \mathrm{mmol})$ is stirred at room temperature in DCM $(3 \mathrm{~mL})$ under an inert atmosphere and the periodinane $(99 \mathrm{mg}, 0.134 \mathrm{mmol})$ is added in one portion. The reaction is stirred until completion (TLC, about 2 hours) then quenched with sodium thiosulphate (saturated solution), extracted 3 times with ethyl acetate, washed with brine, dried over magnesium sulphate, filtered and concentrated in vacuum. The curde product was purified using silica gel flash chromatography eluting with $30 \%$ EtOAc/Hexanes to yield about $36 \mathrm{mg}(90 \%)$ of colorless oil aldehyde $15 . R_{f}=0.50(1: 4$ EtOAc:Hexanes), $[\alpha]_{D}^{25}=-8.4\left(c=1.0, \mathrm{CH}_{2} \mathrm{Cl}_{2}\right)$; IR (neat, $\left.\mathrm{cm}^{-1}\right)$ 2957, 2929, 2856, 1724, 1472, 1385 1360, 1251, 1183, 1096, 1050, 1022, 973, 938, 855, 835, 771, 697672 ; ${ }^{1} \mathrm{H}$ NMR $\left(\mathrm{CDCl}_{3}, 600 \mathrm{MHz}\right) \delta 9.86(\mathrm{t}, J=1.8 \mathrm{~Hz}, 1 \mathrm{H}), 7.50(\mathrm{~m}, 2 \mathrm{H}), 7.33(\mathrm{~m}, 3 \mathrm{H}), 5.76$ (dd, $J=15.6,7.8 \mathrm{~Hz}, 1 \mathrm{H}), 5.60(\mathrm{~s}, 1 \mathrm{H}), 5.51$ (dd, $J=15.6,5.4 \mathrm{~Hz}, 1 \mathrm{H}), 4.43(\mathrm{~m}, 1 \mathrm{H})$, $4.36(\mathrm{~m}, 1 \mathrm{H}), 3.29(\mathrm{dd}, J=5.4,4.2 \mathrm{~Hz}, 1 \mathrm{H}), 2.82(\mathrm{dd}, J=16.8,7.2 \mathrm{~Hz}, 1 \mathrm{H}), 2.62(\mathrm{dd}, J=$ 16.8, $5.4 \mathrm{~Hz}, 1 \mathrm{H}), 2.34(\mathrm{~m}, 1 \mathrm{H}), 1.74(\mathrm{~m}, 1 \mathrm{H}), 1.72(\mathrm{~m}, 1 \mathrm{H}), 1.60(\mathrm{~m}, 1 \mathrm{H}), 1.00(\mathrm{~d}, J=$ $7.2 \mathrm{~Hz}, 3 \mathrm{H}), 0.91$ (s, 9H), 0.89 (d, $J=7.2 \mathrm{~Hz}, 3 \mathrm{H}), 0.85$ (d, $J=7.2 \mathrm{~Hz}, 3 \mathrm{H}), 0.04$ (s, 6H); ${ }^{13} \mathrm{C}$ NMR $\left(\mathrm{CDCl}_{3}, 150 \mathrm{MHz}\right) \delta$ 200.2, 138.2, 136.7, 128.7, 128.1, 128.0, 126.1, 100.7, $80.7,77.2,71.7,49.3,40.7,36.8,31.6,26.1,20.5,18.4,17.6,15.9,-3.5,-3.7$; HRMS (ESI) calcd for $\left[\mathrm{C}_{26} \mathrm{H}_{42} \mathrm{O}_{4} \mathrm{Si}+\mathrm{Na}\right]^{+}: 469.2745$ Found: 469.2750 .

(-)-(S)-1-((2R,4R,6R)-6-((E,3S,4S)-4-(tert-butyldimethylsilyloxy)-3,5-dimethylhex-1enyl)-2-phenyl-1,3-dioxan-4-yl)pent-4-en-2-ol (12a). 


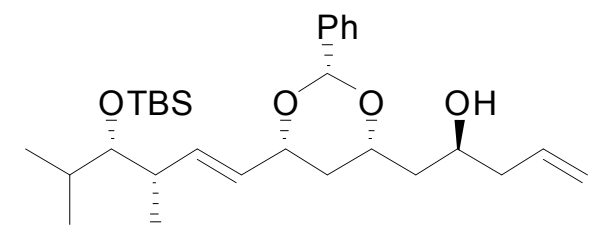

A solution of aldehyde $15(10 \mathrm{mg}, 0.022 \mathrm{mmol})$ in $\mathrm{CH}_{2} \mathrm{Cl}_{2}(1 \mathrm{~mL})$ was cooled to $-15^{\circ} \mathrm{C}$ in a salt-ice bath and was added via cannula to a separate RBF containing allyl silane $\left[(R, R)\right.$-Leighton reagent] $(16 \mathrm{mg}, 0.067 \mathrm{mmol})$ in $\mathrm{CH}_{2} \mathrm{Cl}_{2}(1 \mathrm{~mL})$ at $-15^{\circ} \mathrm{C}$. The reaction was then placed in the freezer and allowed to react for $2 \mathrm{~h}$. The reaction mixture was then diluted with EtOAc $(5 \mathrm{~mL})$ and filtered through a plug of Celite to remove the white precipitate that had formed after several minutes stirring with EtOAc. The filtrate was then washed with sat. aq. $\mathrm{NaHCO}_{3}(10 \mathrm{~mL})$ and brine $(10 \mathrm{~mL})$. The organics were then dried over $\mathrm{Na}_{2} \mathrm{SO}_{4}$. After concentration the crude mixture was purified immediately by silica gel column chromatography (10\% EtOAc/5\% MeOH/Hexanes) to yield $10 \mathrm{mg}$ $(90 \%)$ of homoallylic alcohol 12a. $[\alpha]^{25}=-2.3\left(c=1.0, \mathrm{CH}_{2} \mathrm{Cl}_{2}\right)$; IR (neat, $\left.\mathrm{cm}^{-1}\right) 3441$ (br), 2955, 2930, 2856, 1472, 1461, 1385, 1337, 1251, 1215, 1097, 1052, 1022, 974, 914, 857, 835, 772, 697, 673; ${ }^{1} \mathrm{H}$ NMR $\left(\mathrm{CDCl}_{3}, 600 \mathrm{MHz}\right) \delta 7.50(\mathrm{~m}, 2 \mathrm{H}), 7.33(\mathrm{~m}, 3 \mathrm{H}), 5.84$ (m, 1H), $5.75(\mathrm{dd}, J=15.6,7.8 \mathrm{~Hz}, 1 \mathrm{H}), 5.59(\mathrm{~s}, 1 \mathrm{H}), 5.52(\mathrm{dd}, J=15.6,6.6 \mathrm{~Hz}, 1 \mathrm{H})$, $5.13(\mathrm{~m}, 2 \mathrm{H}), 4.33(\mathrm{ddd}, J=9.6,6.6,1.8 \mathrm{~Hz}, 1 \mathrm{H}), 4.20(\mathrm{dddd}, J=10.8,8.4,3.0,3.0 \mathrm{~Hz}$, 1H), $4.04(\mathrm{~m}, 1 \mathrm{H}), 3.29(\mathrm{dd}, J=5.4,4.2 \mathrm{~Hz}, 1 \mathrm{H}), 2.34(\mathrm{~m}, 1 \mathrm{H}), 2.26(\mathrm{~m}, 2 \mathrm{H}), 1.71(\mathrm{~m}$, 4H), $1.61(\mathrm{~m}, 1 \mathrm{H}), 0.99$ (d, $J=6.6 \mathrm{~Hz}, 3 \mathrm{H}), 0.91(\mathrm{~s}, 9 \mathrm{H}), 0.89$ (d, $J=7.2 \mathrm{~Hz}, 3 \mathrm{H}), 0.85$ $(\mathrm{d}, J=6.6 \mathrm{~Hz}, 3 \mathrm{H}), 0.04(\mathrm{~s}, 6 \mathrm{H}) ;{ }^{13} \mathrm{C} \mathrm{NMR}\left(\mathrm{CDCl}_{3}, 150 \mathrm{MHz}\right) \delta 138.6,136.4,134.7$, 128.6, 128.4, 128.1, 126.1, 118.0, 100.7, 80.7, 77.5, 74.0, 67.0, 42.2, 42.1, 40.7, 37.0, 31.6, 26.1, 20.5, 18.4, 17.6, 15.9, -3.5, -3.7; HRMS (ESI) calcd for $\left[\mathrm{C}_{29} \mathrm{H}_{48} \mathrm{O}_{4} \mathrm{Si}+\mathrm{Na}\right]^{+}$: 511.3214 Found: 511.3220. 


\subsection{REFERENCES:}

${ }^{1}$ Brown, H.C.; Jadhav, P. K. J. Am. Chem. Soc. 1983, 105, 2092-2093.

${ }^{2}$ Brown, H.C.; Bhat, K. S. J. Am. Chem. Soc. 1986, 108, 5919-5923.

${ }^{3}$ Roush, W. R.; Walts, A. E.; Hoong, L.K. J. Am. Chem. Soc. 1985, 107, 8186-8190.

${ }^{4}$ Leighton, J. L.; Kubota, K.; Angew. Chem. Int. Ed. 2003, 42, 946-948.

${ }^{5}$ Keck, G. E.; Tarbet, K. H.; Geraci, L. S. J. Am. Chem. Soc. 1993, 115, 8467-8468.

${ }^{6}$ Keck, G. E.; Krishnamurthy, D.; Grier, M. C. J. Org. Chem. 1993, 58, 6543-6544.

${ }^{7}$ Carreira, E. M.; Gauthier, D. R. Jr. Angew. Chem. Int. Ed. Engl. 1996, 35, 2363-2365.

${ }^{8}$ Kimbrough, R. D. Environ. Health Perspect. 1976, 14, 51-56.

${ }^{9}$ Mclaughlin J. K.; Chow W-H.; Levy L. S. Journal of Toxicology and Environmental Health 1997, 50, $553-566$.

${ }^{10}$ Hlubucek, J. R.; Robertson, A. V. Aust. J. Chem. 1967, 20, 2199-2206.

${ }^{11}$ Cavalheiro, A.J; Yoshida, M. Phytochemistry 2000, 53, 811-819.

${ }^{12}$ Kabir, K. E.; Khan, A. R.; Mosaddik, M. A. J. Appl. Ent. 2003, 127, 112-115.

${ }^{13}$ (a) Goniothalamus giganteus: El-Zayat, A. E.; Ferrigni, N. R; McCloud, T. G.; McKenzie, A. T.; Byrn, S. R.; Cassady, J. M.; Chang, C.; McLaughlin, J. L. Tetrahedron Lett. 1985, 26, 955-956. (b)

Goniothalamus waroids: Ahmed, F. B.; Tukol, W. A.; Omar, S.; Sharif, A. M. Phytochemistry 1991, 30, 2430-2431. (c) Goniothalamus malayanus, G. andersonni, G. macrophyllus: Jewers, K.; Blunden, G.;

Wetchapinan, S.; Dougan, J.; Manchada, A. H.; Davis, J. B.; Kyi, A. Phytochemistry 1972, 11, 2025-2030.

${ }^{14}$ Marko, I. E.; Pospisil, J. Tetrahedron Lett. 2006, 47, 5933-5937.

${ }^{15}$ (a) Ramachandran, P. V.; Chandra, J. S.; Reddy, M. V. R. J. Org. Chem. 2002, 67, 7547-7550. (b) Goh, S. H.; Ee, G. C. L.; Chuah, C. H.; Wei, C. Aust. J. Chem. 1995, 48, 199-205. (c) Fatima, A. D.; Pilli, R. A. Tetrahedron Lett. 2003, 44, 8721-9724.

${ }^{16}$ Bose, D. S.; Reddy, A. V. N.; Srikanth, B. Synthesis 2008, 15, 2323-2326.

${ }^{17}$ (a) Kobinata, K.; Koshino, H.; Kudo, T.; Isono, K.; Osada, H. J. Antibio. 1993, 46, 1616-1618. (b)

Koshino, H.; Kobinata, K.; Isono, K.; Osada, H. J. Antibio. 1993, 46, 1619-1621.

${ }^{18}$ Burova, S. A.; McDonald, F. E. J. Am. Chem. Soc. 2004, 126, 2495-2500.

${ }^{19}$ Denmark, S. E.; Fujimori, S. J. Am. Chem. Soc. 2005, 127, 8971-8973. 
${ }^{20}$ Mitton-Fry, M. J.; Cullen, A. J.; Sammakia, T. Angew. Chem. Int. Ed. 2007, 46, 1066-1070.

${ }^{21}$ Guo, H.; Mortensen, M. S.; O’Doherty, G. A. Org. Lett. 2008, 10, 3149-3152.

${ }^{22}$ Kim, I. S.; Ngai, M.; Krische, M. J. J. Am. Chem. Soc. 2008, 130, 14891-14899.

${ }^{23}$ Nakajima, M.; Saito, M.; Shiro, M.; Hashimoto, S. J. Am. Chem. Soc. 1998, 120, 6419.

${ }^{24}$ Schmidt, B. J. Org. Chem. 2004, 69, 7672.

${ }^{25}$ Sam, T.W.; Sew-Yeu, C.; Matsjeh, S.; Gan, E.K.; Razak, D.; Mohamed, A. Tetra. Lett. 1987, 28, 25412544.

${ }^{26}$ Powell, S. A.; Tenenbaum, J. M.; Woerpel, K. A. J. Am. Chem. Soc. 2002, 124, 12648-12649.

${ }^{27}$ Rychnovsky, S. D.; Rodriguez, C. J. Org. Chem. 1992, 57, 4793-4795.

${ }^{28}$ Paterson, I; Collett, L. A. Tetrahedron Lett. 2001, 6, 1187-1191.

${ }^{29}$ Rychnovsky, S. D.; Hoye, R. C. J. Am. Chem. Soc. 1994, 5, 1753-1765. 
Appendix 


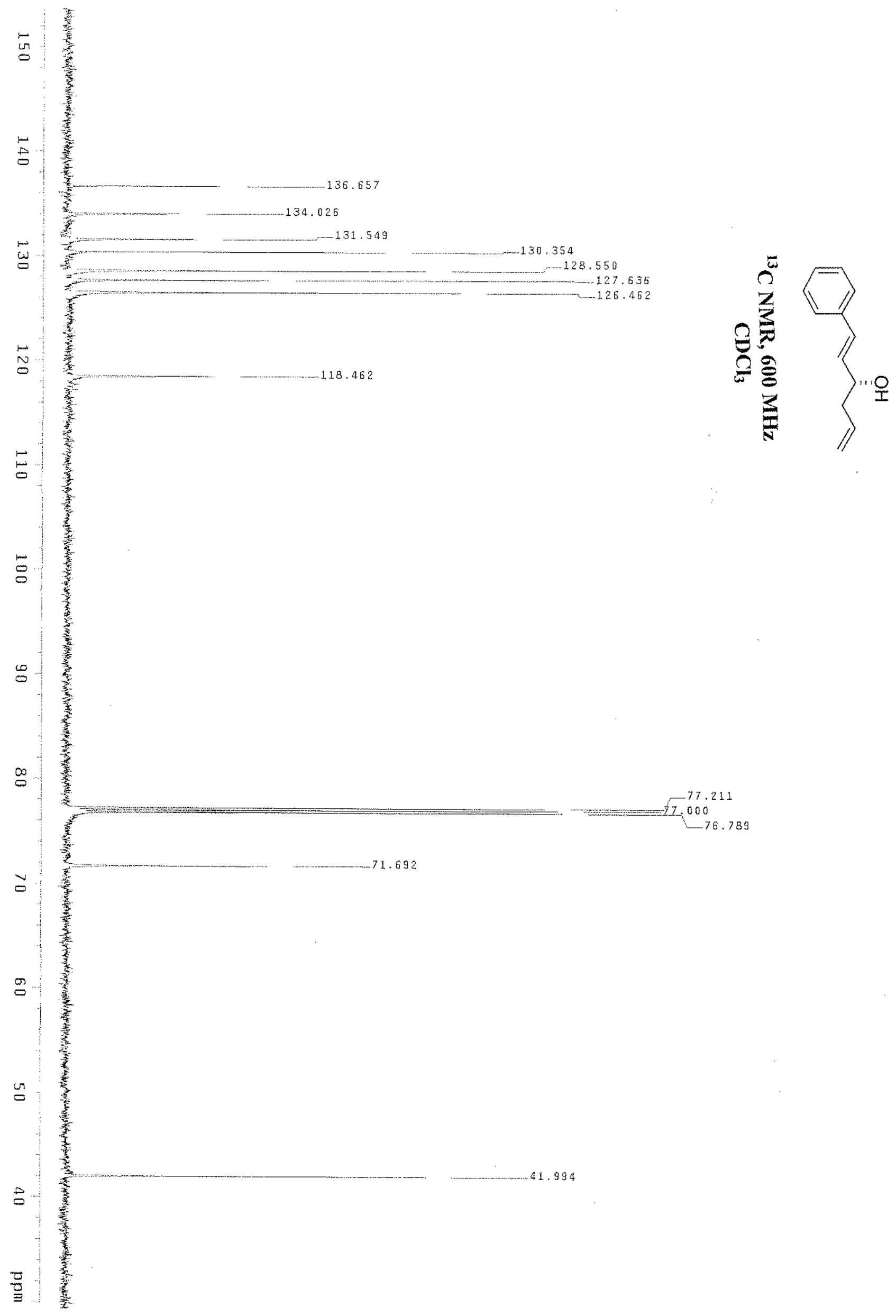




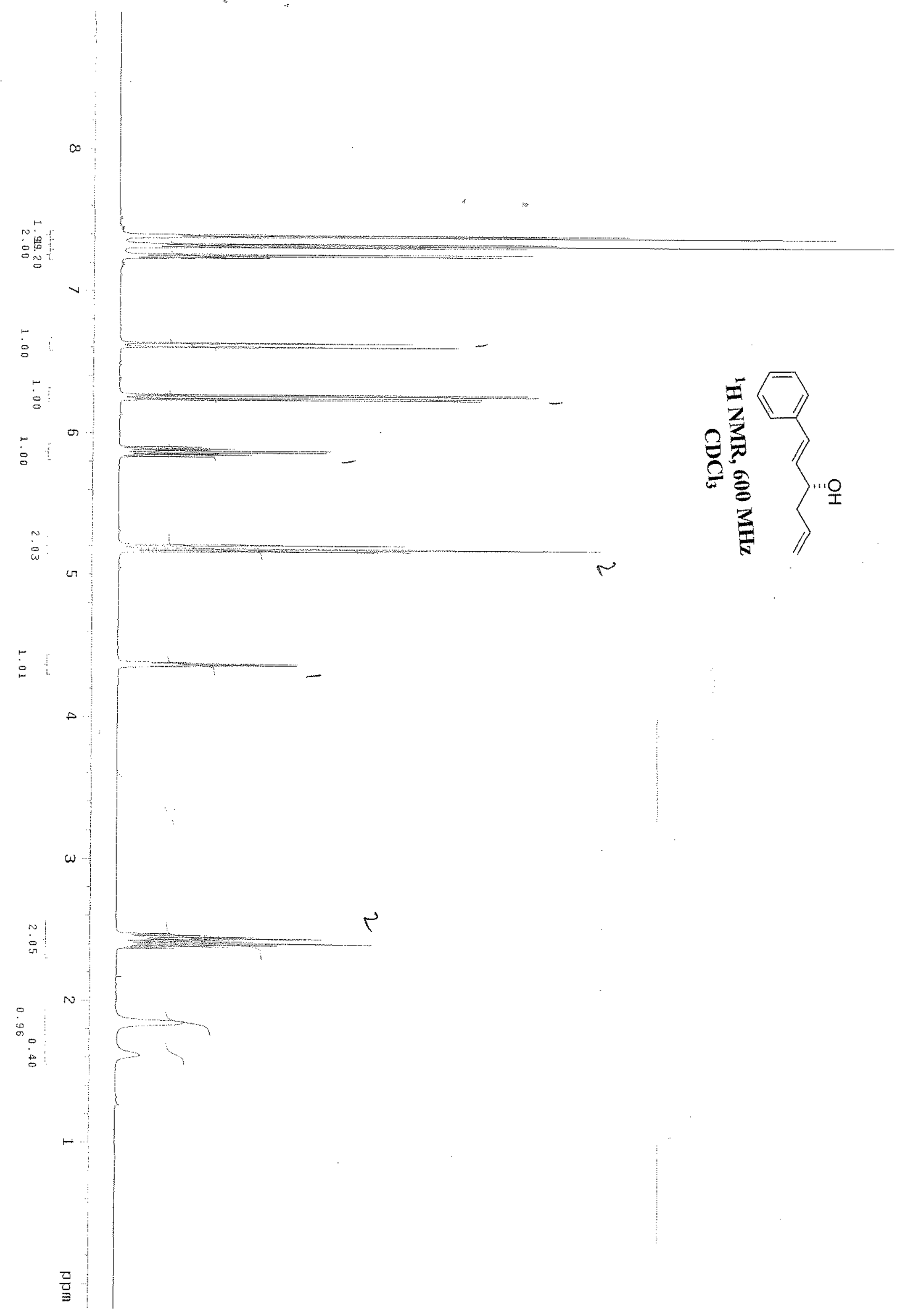




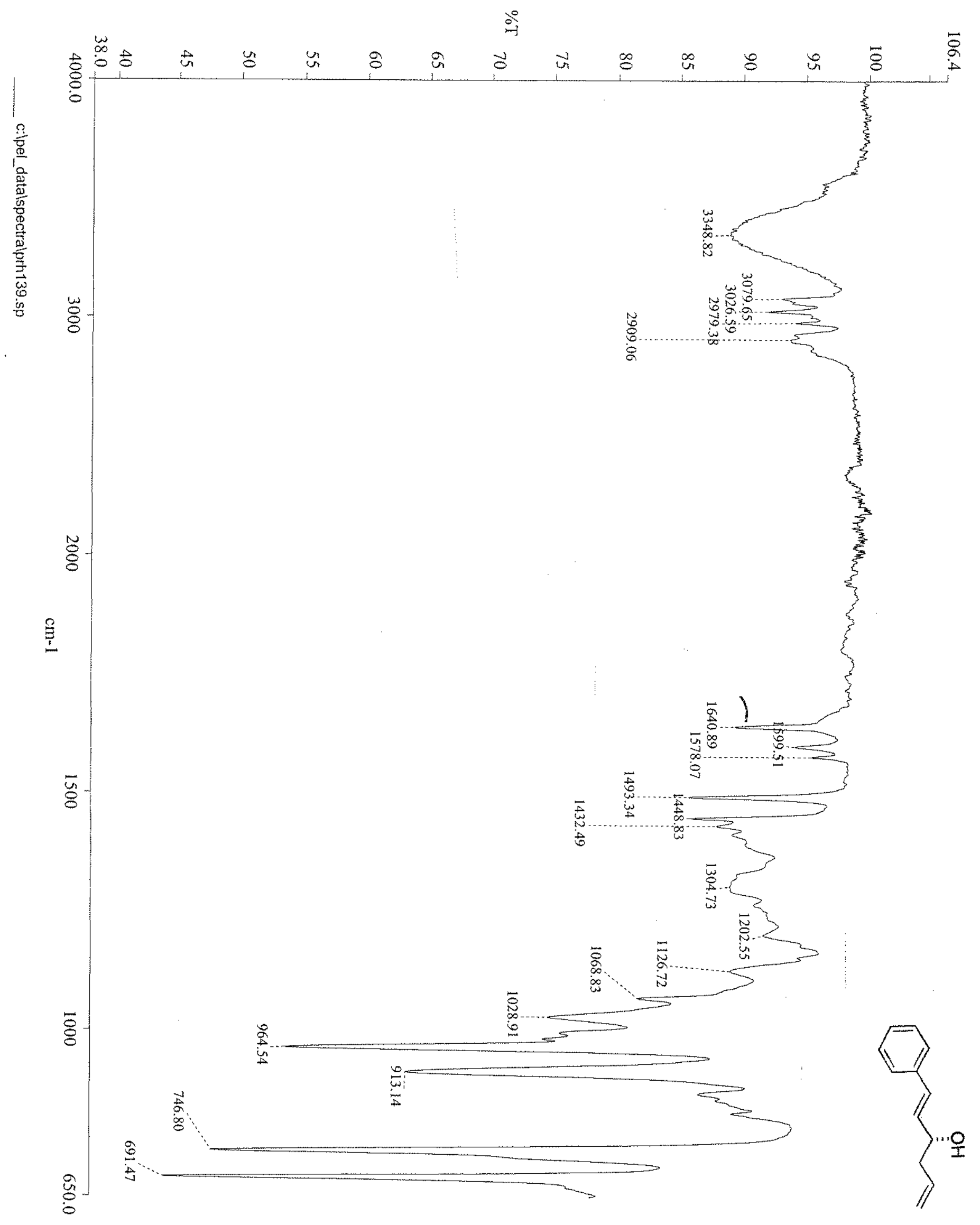




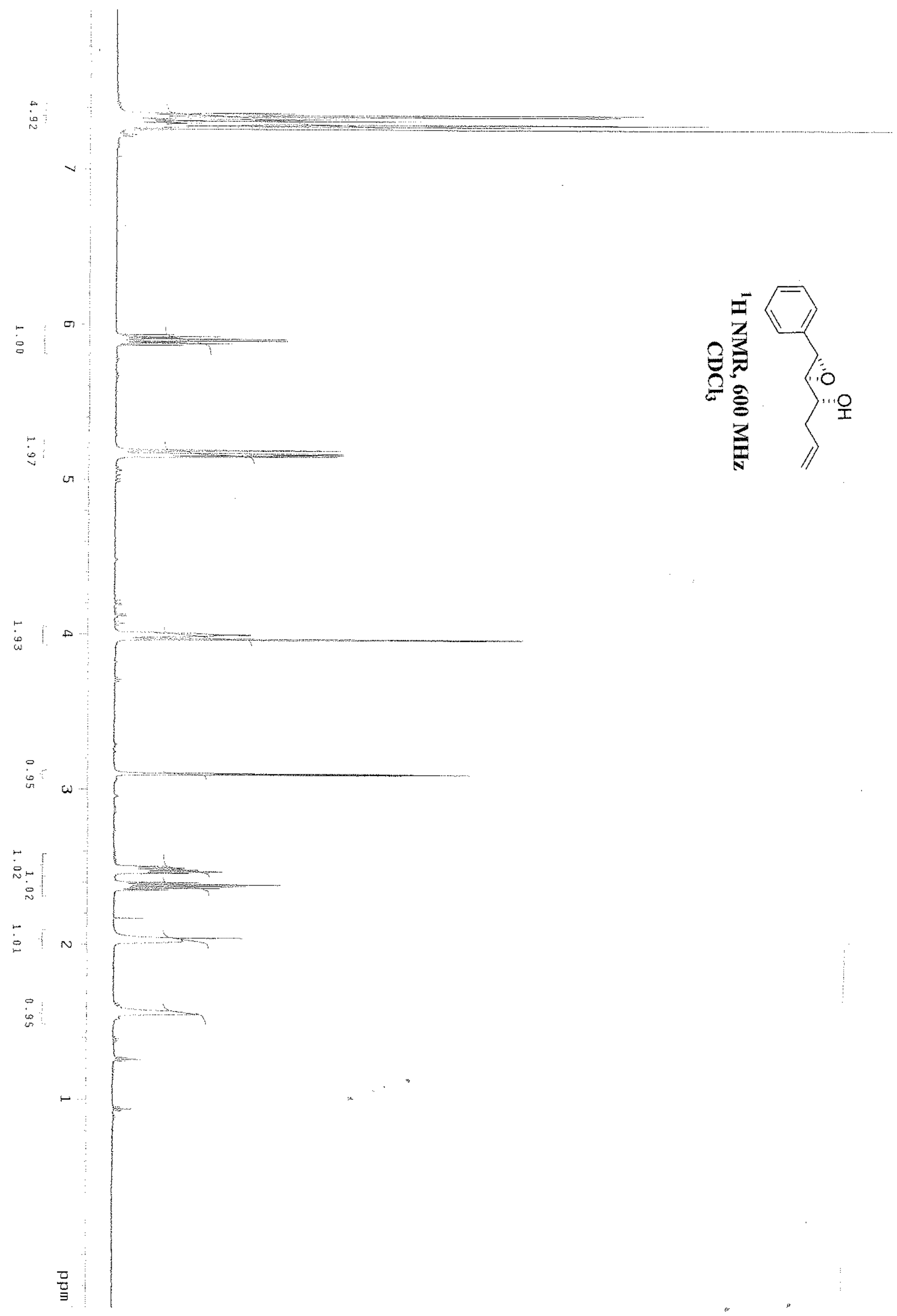




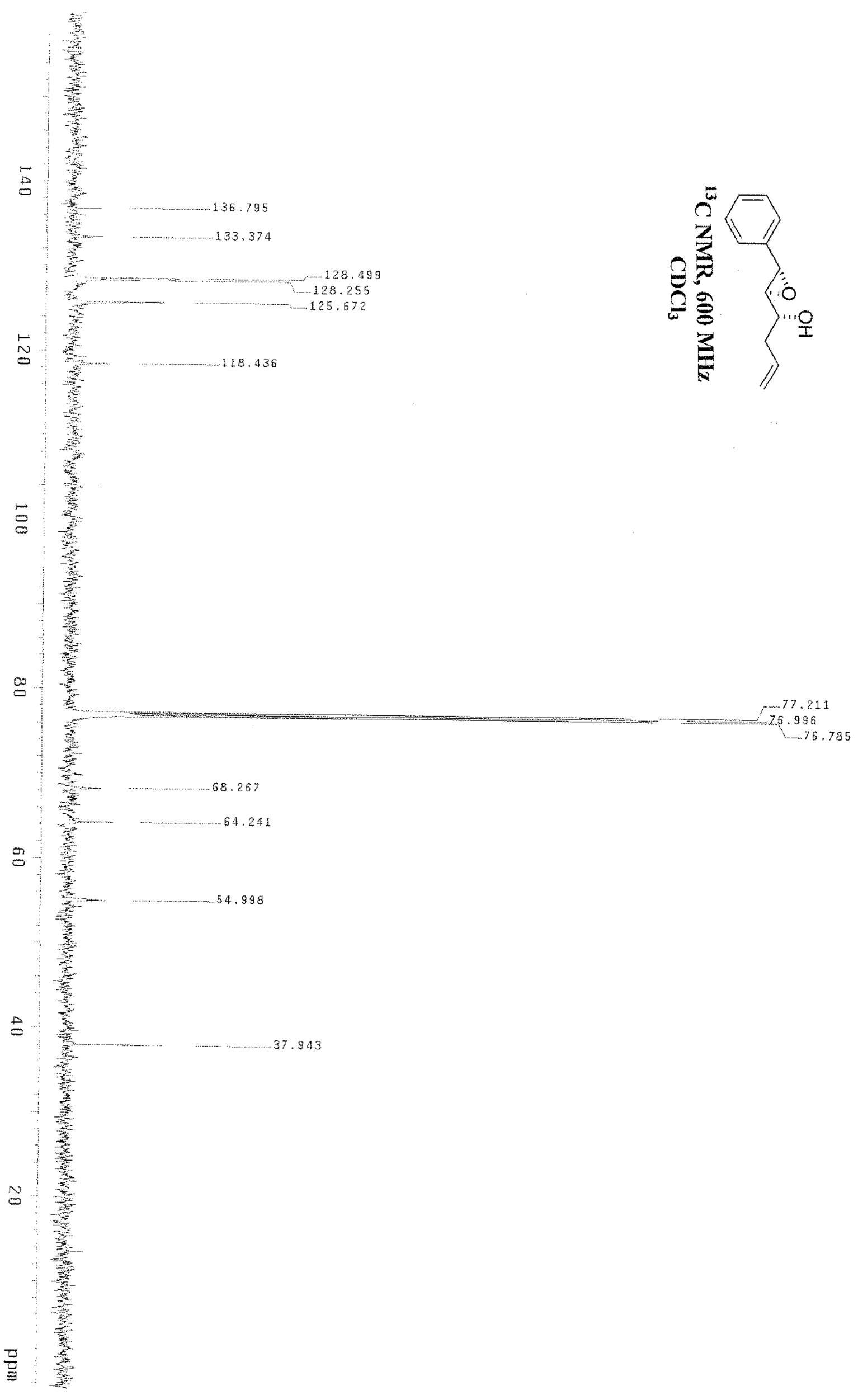




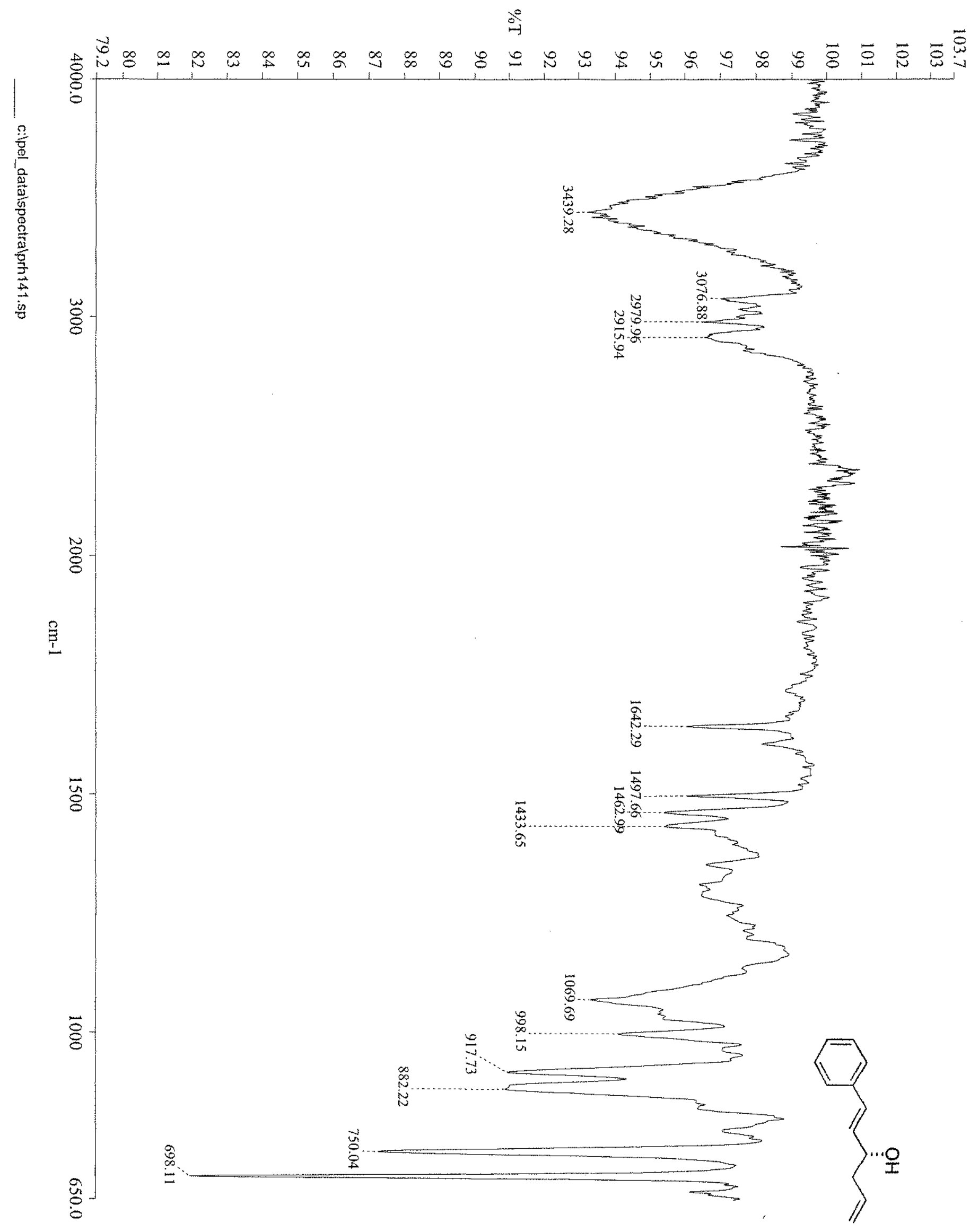




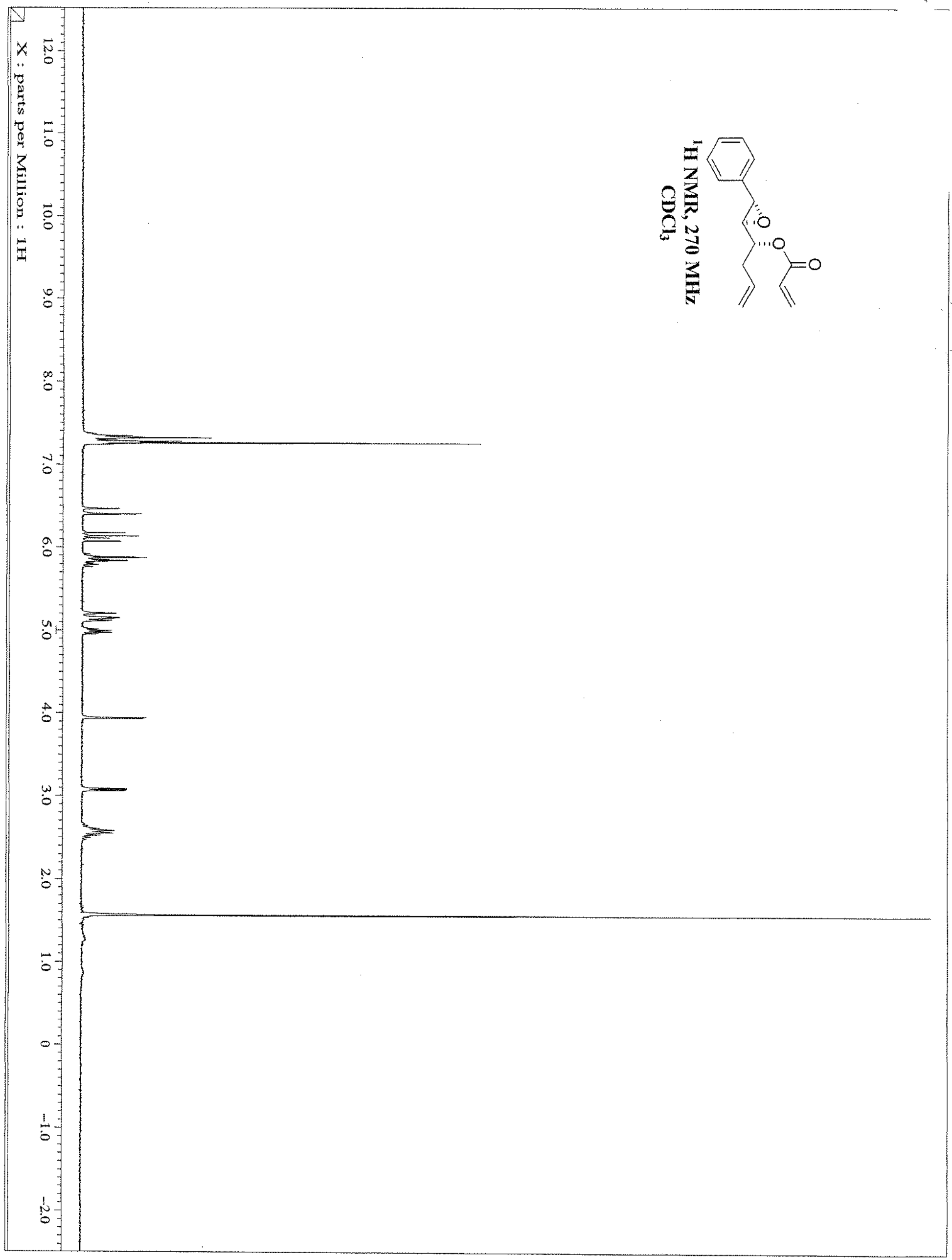




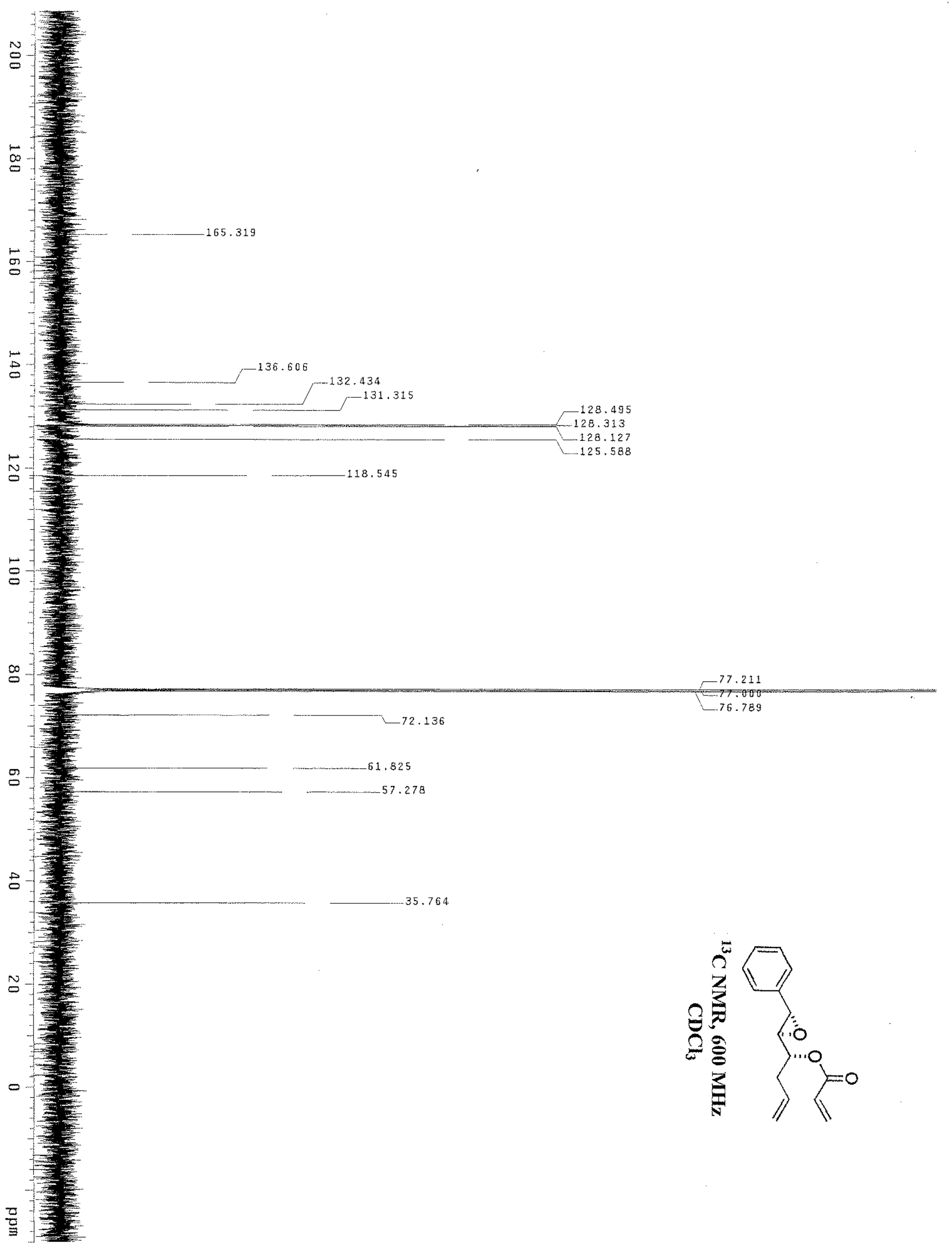




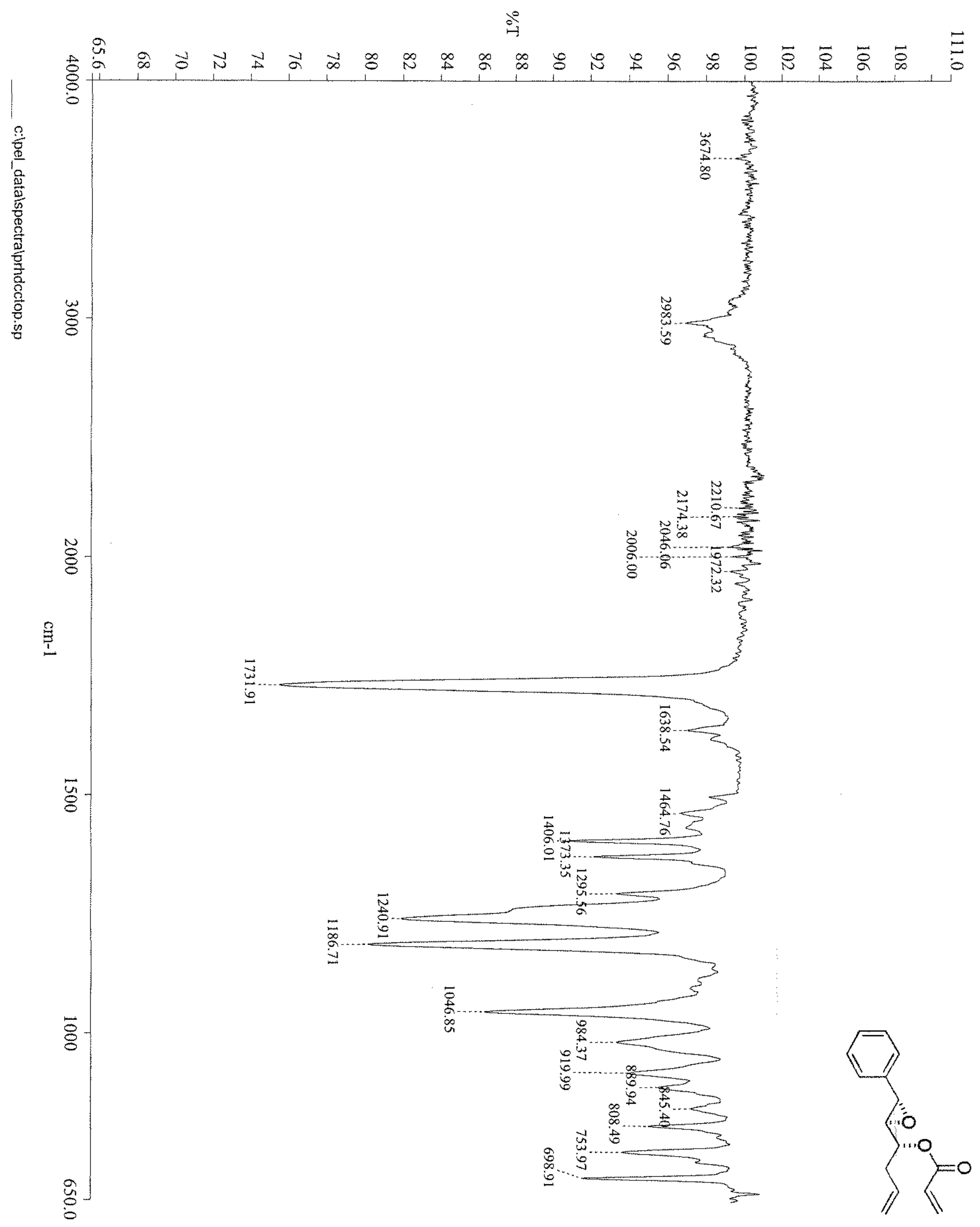




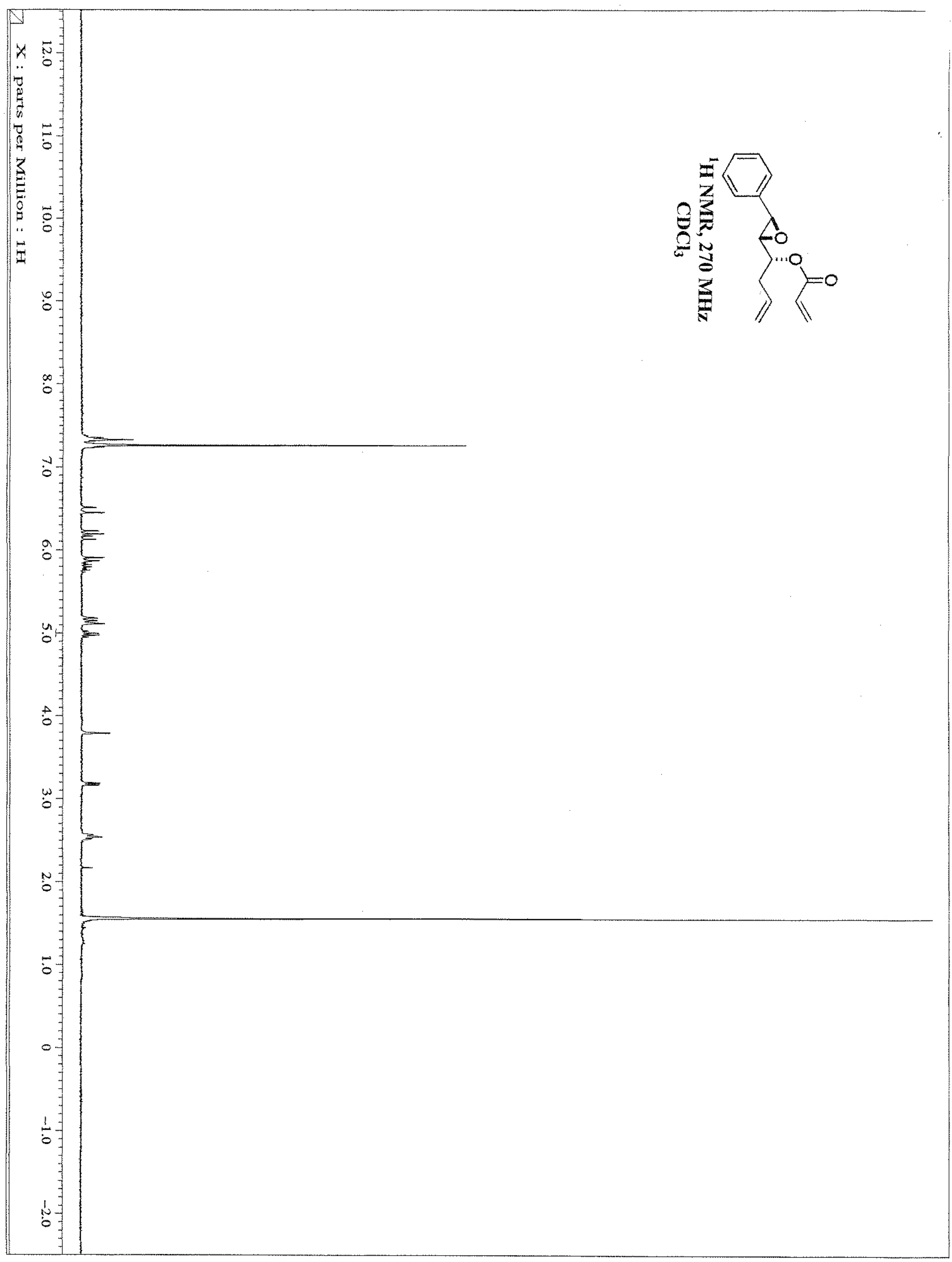




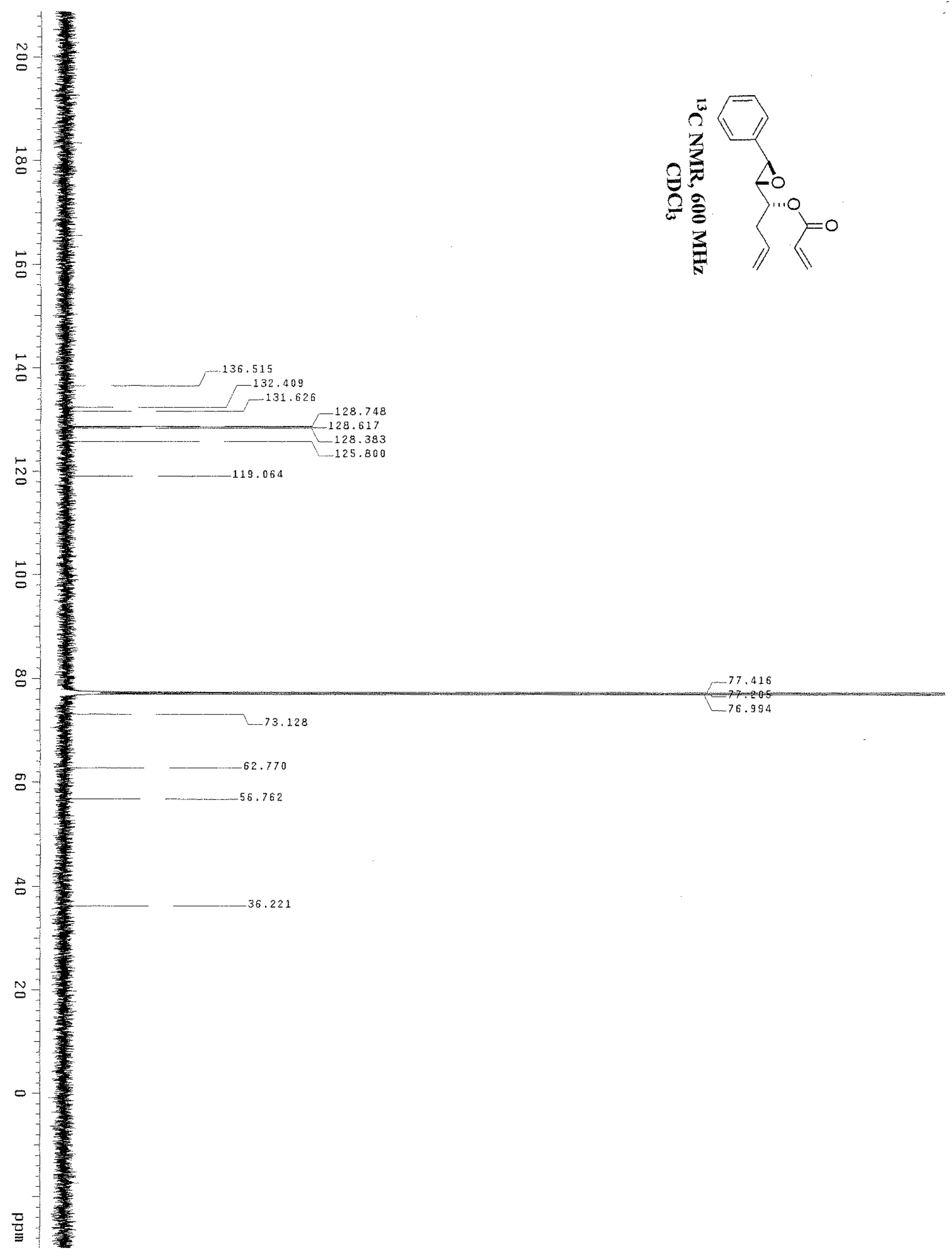




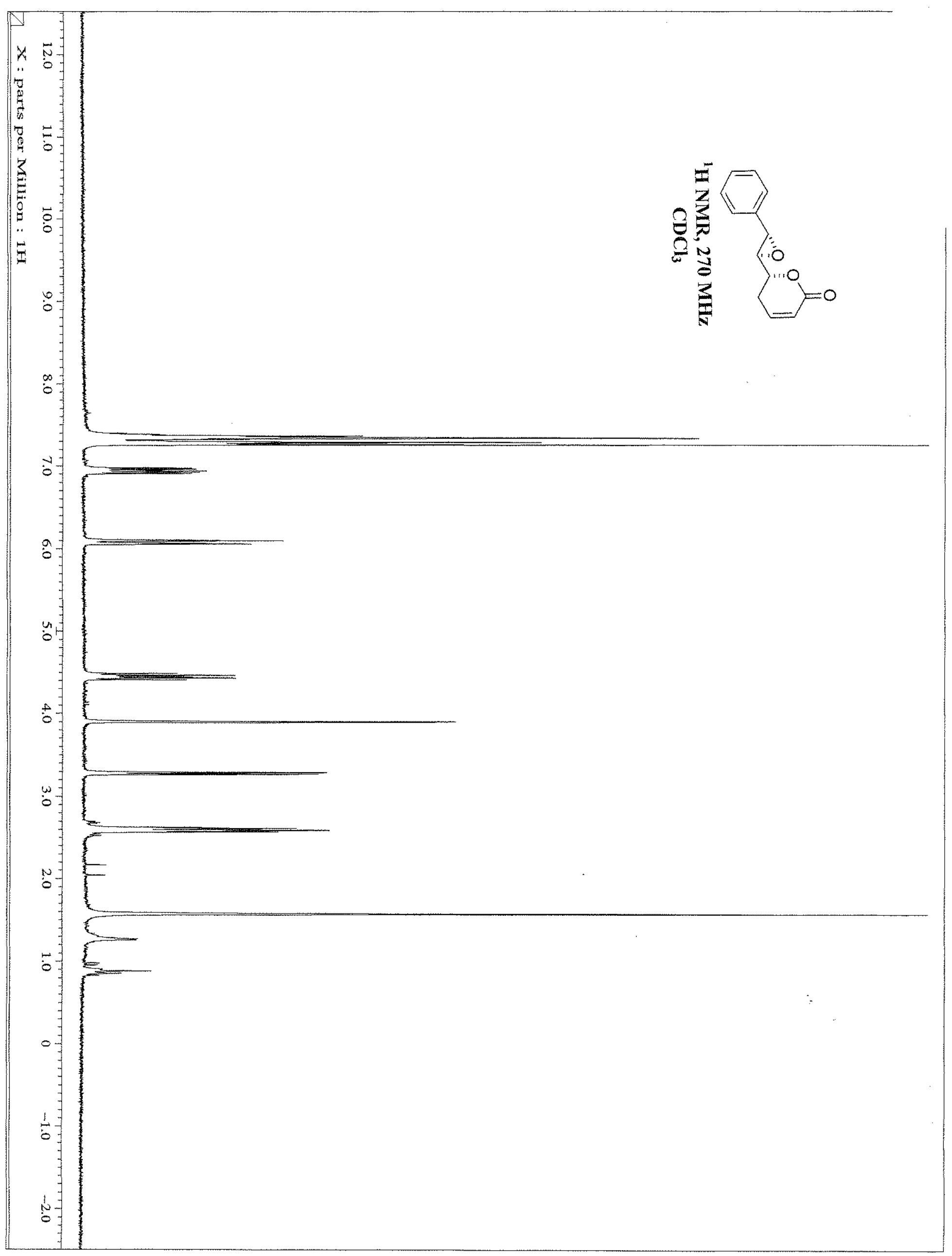




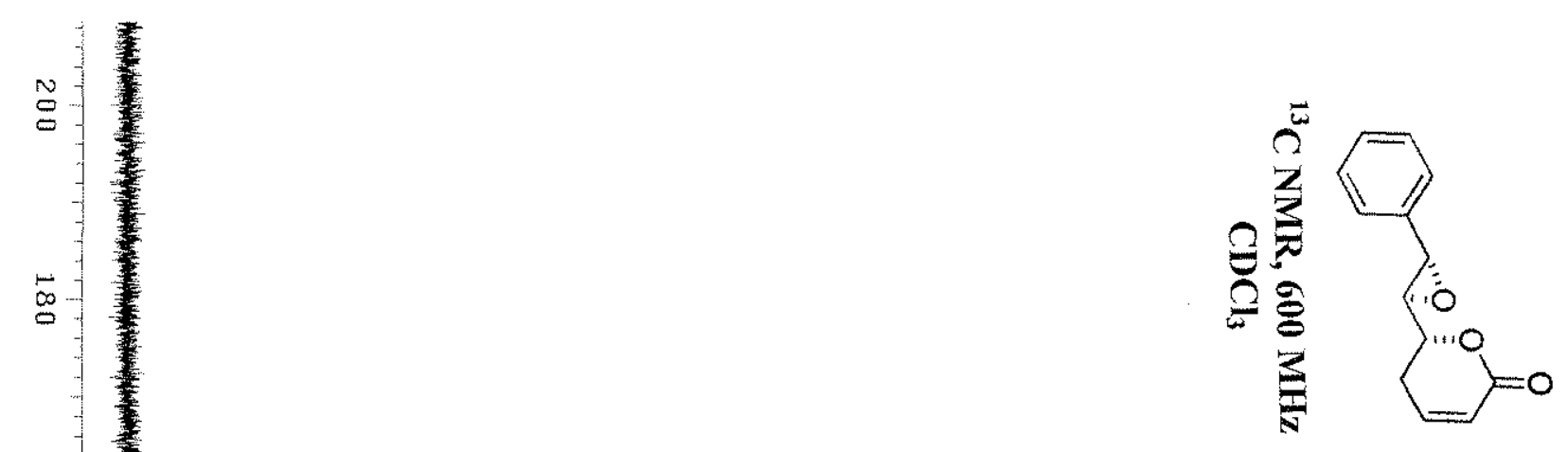




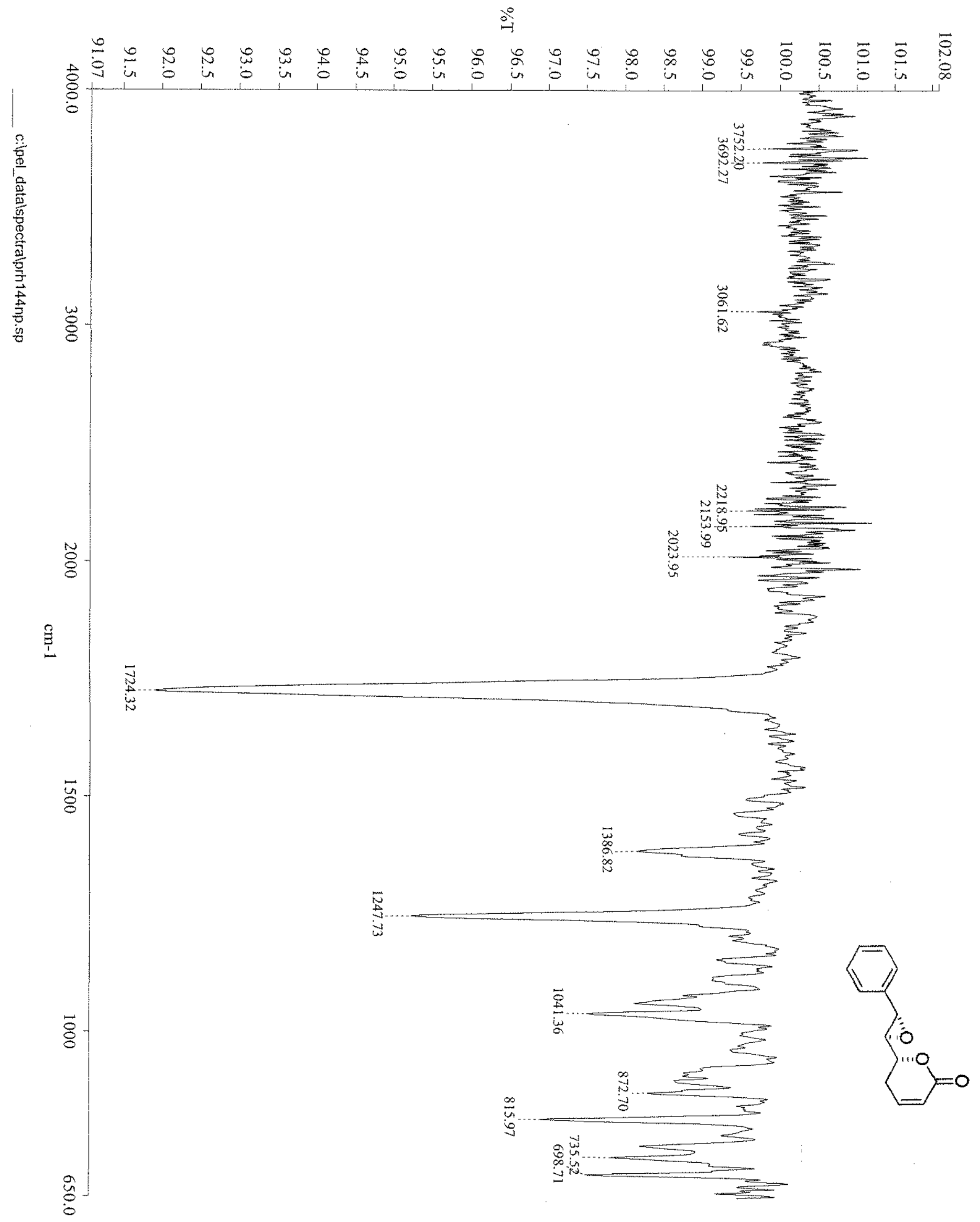




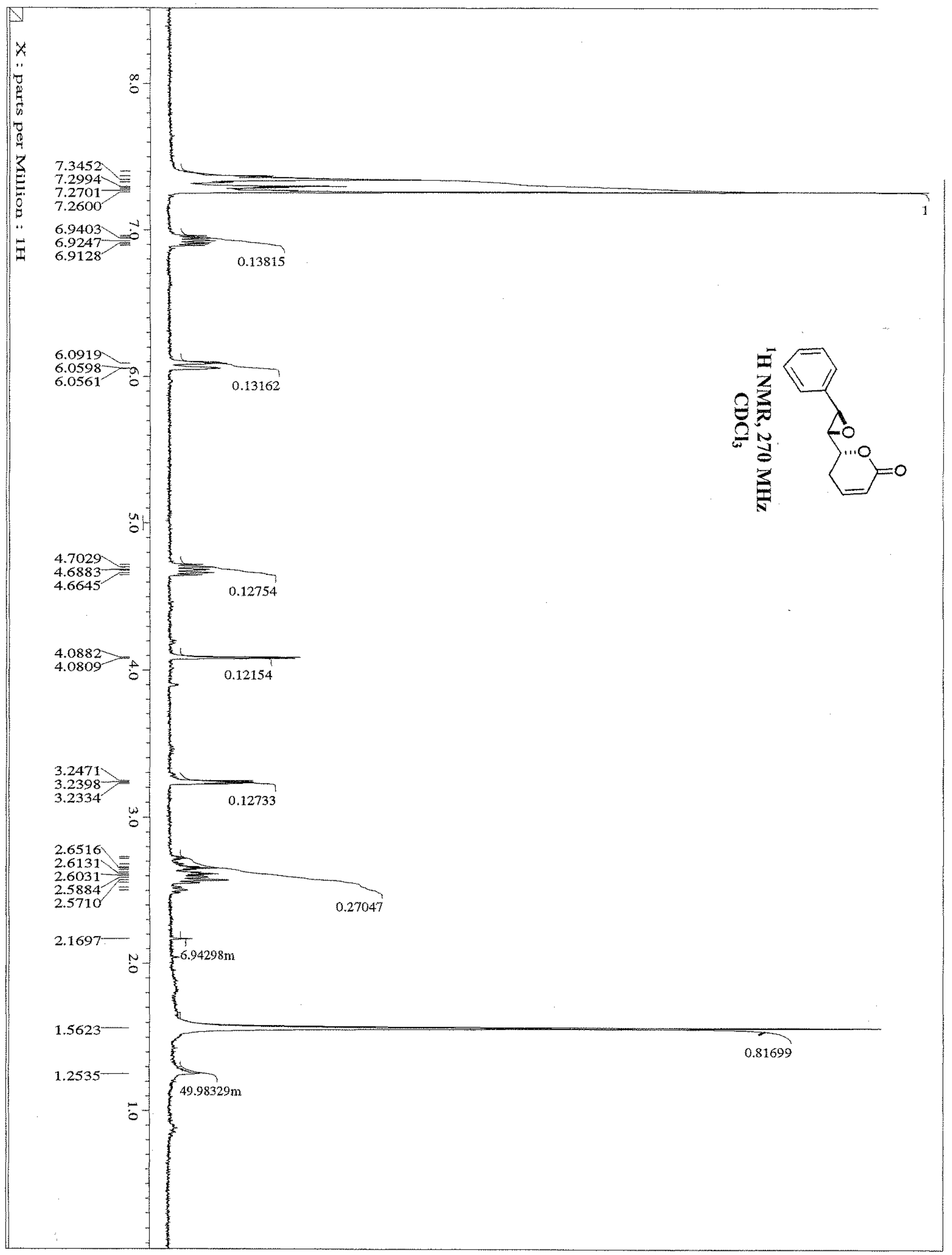




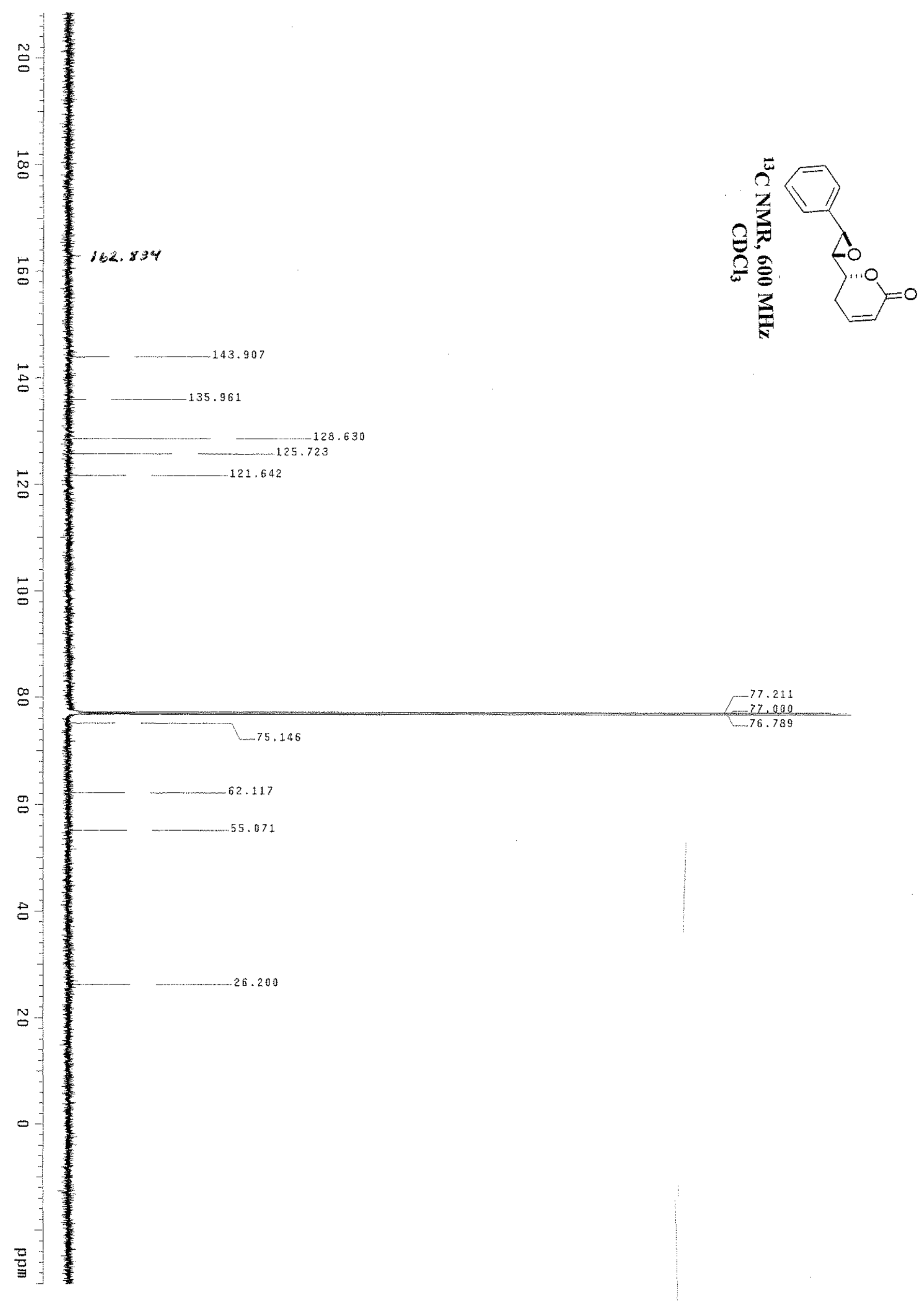




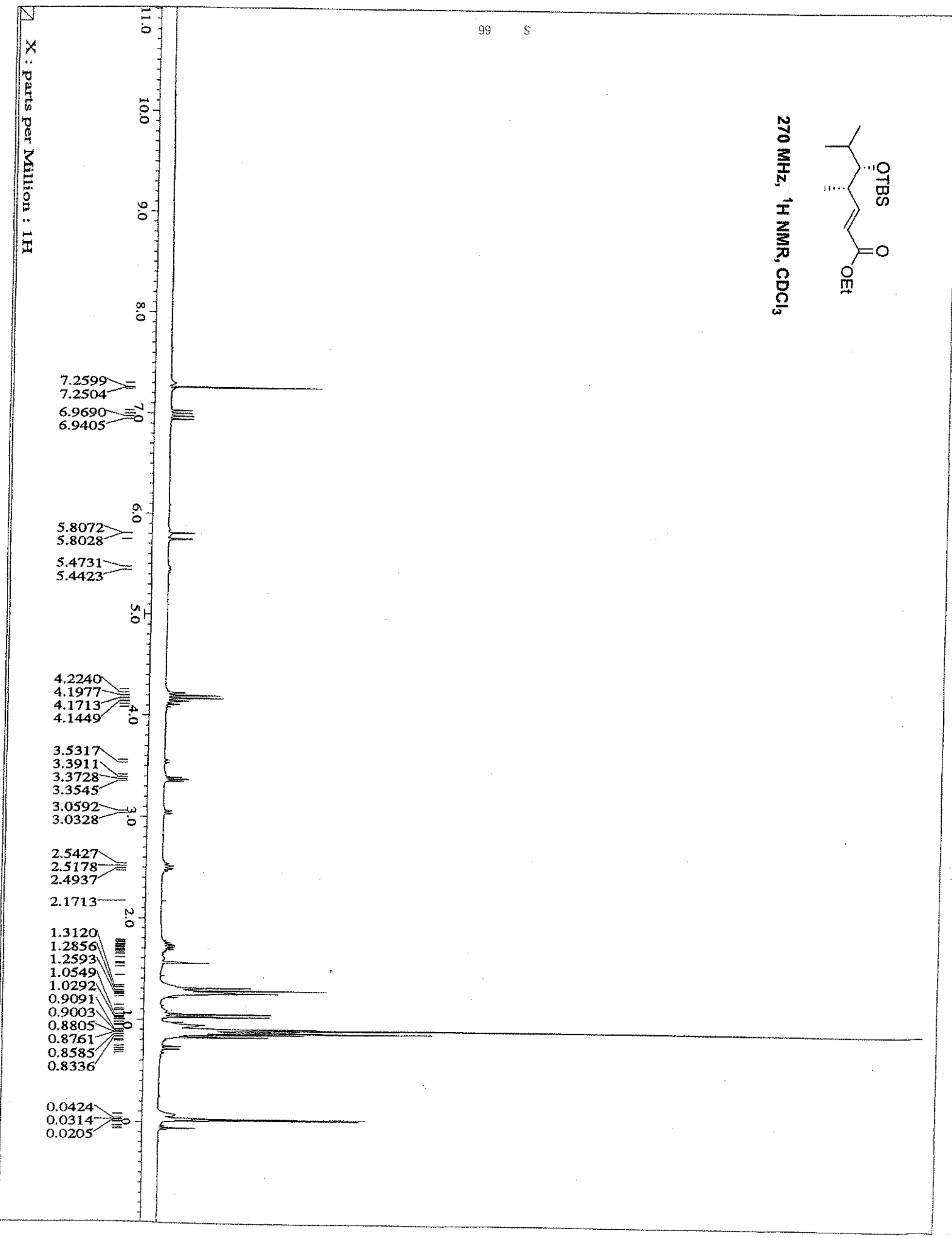




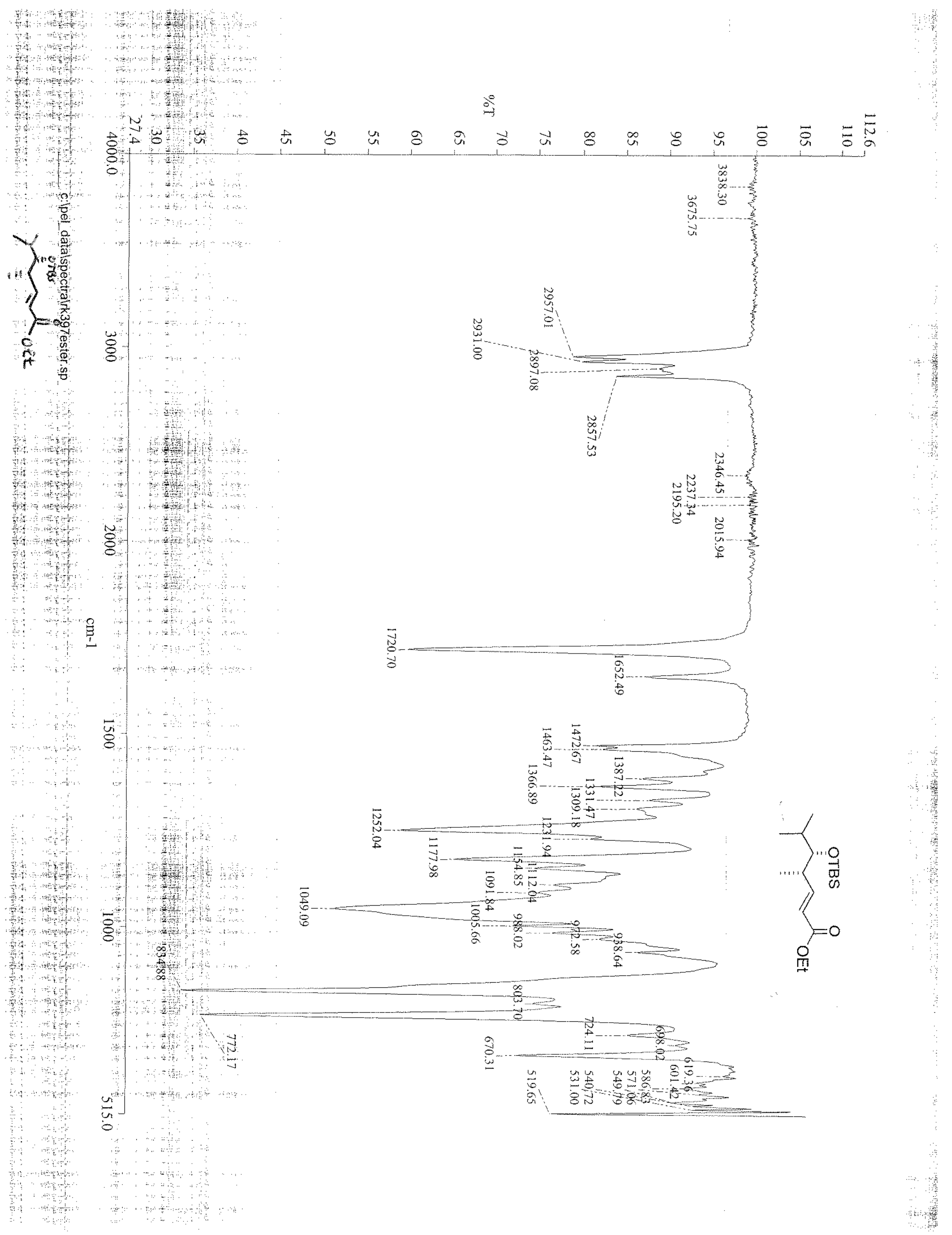




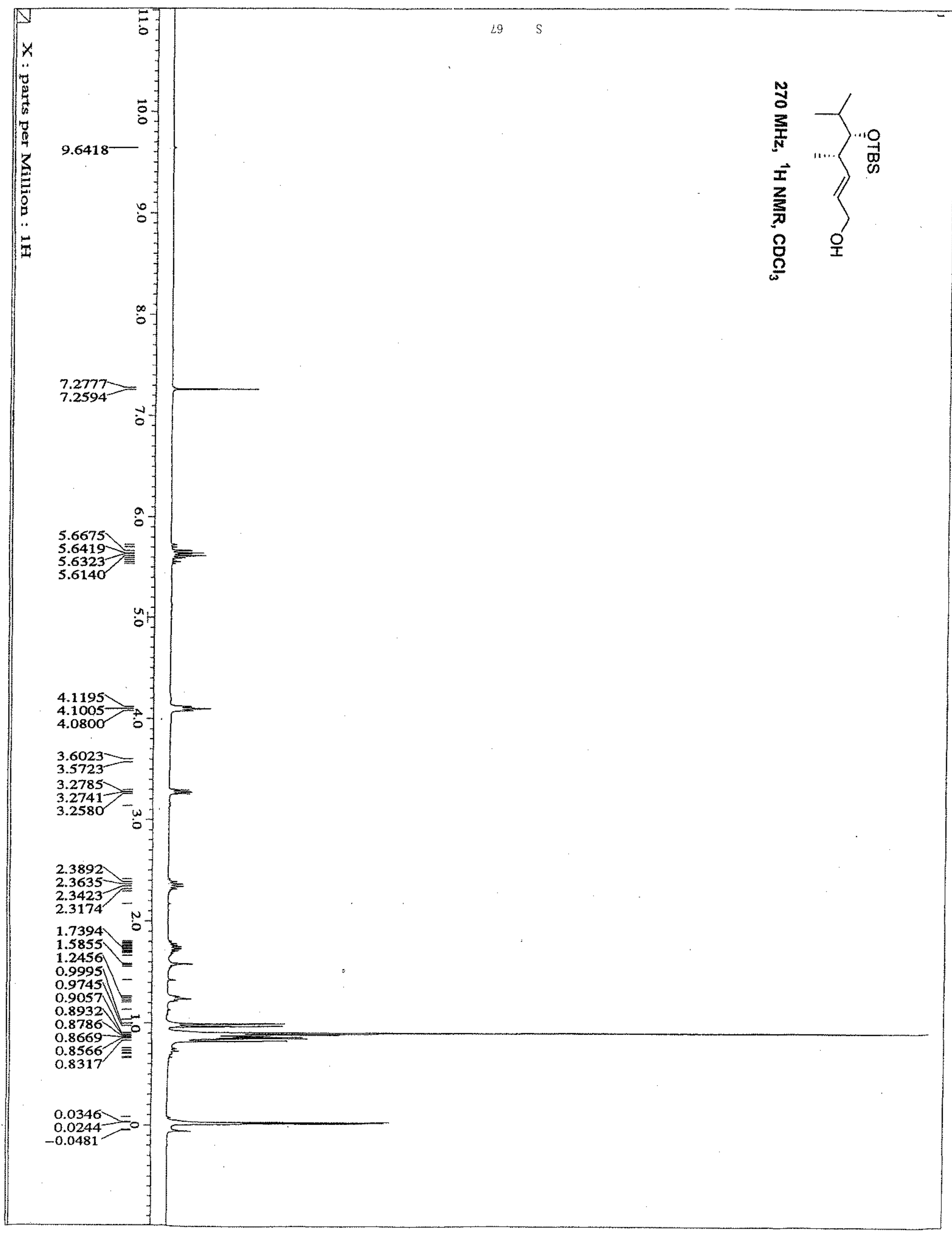




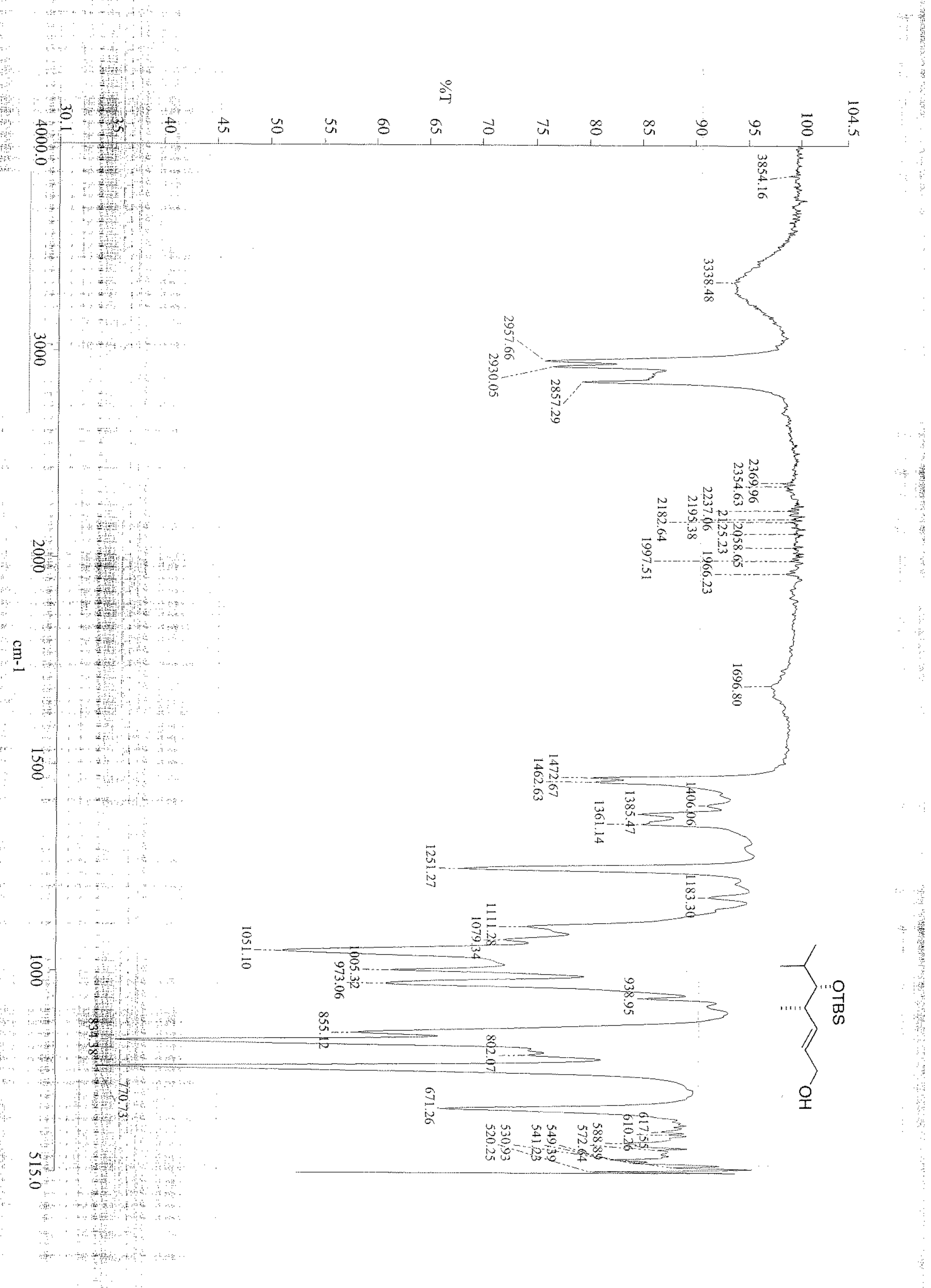




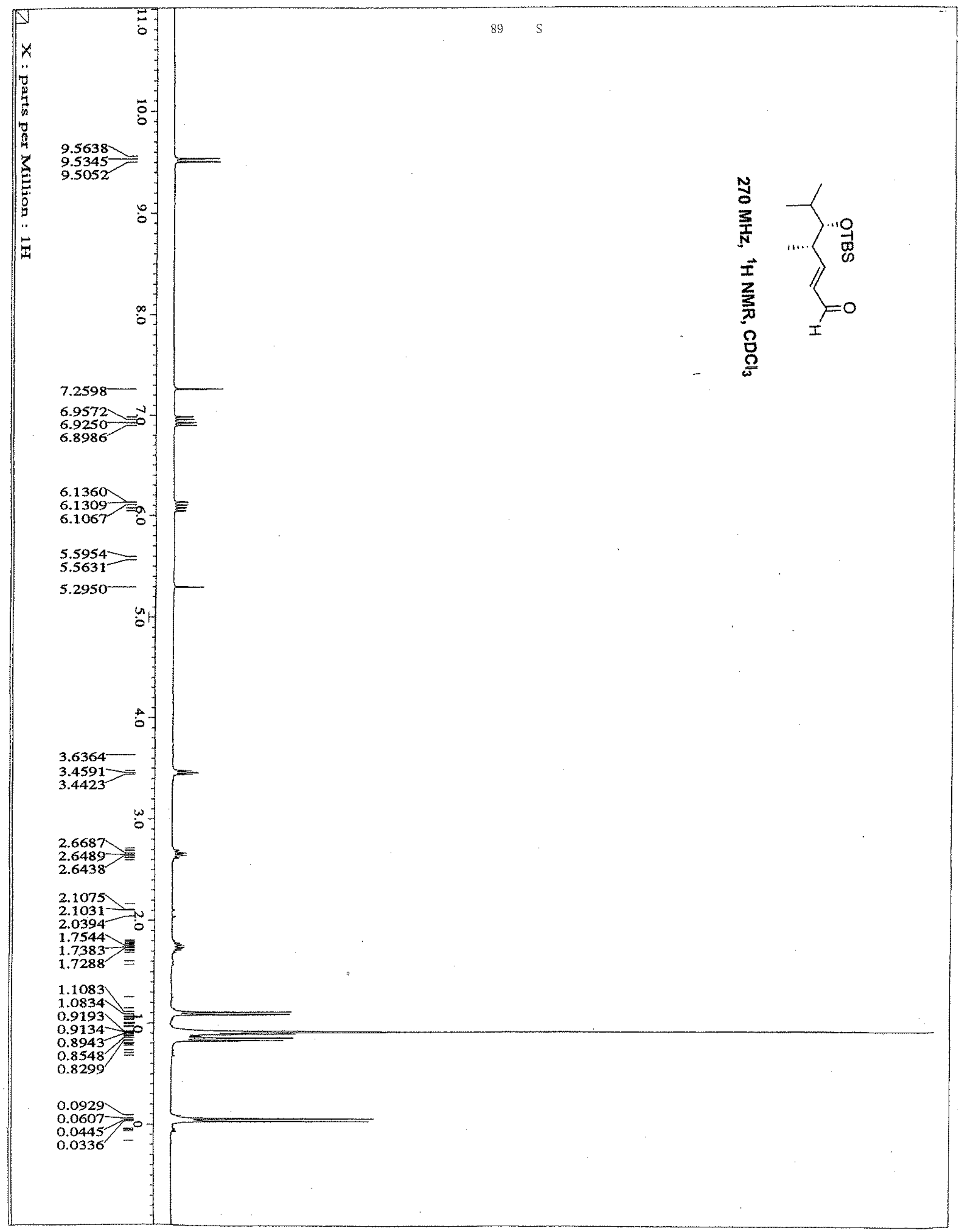




$$
\text { t. }
$$




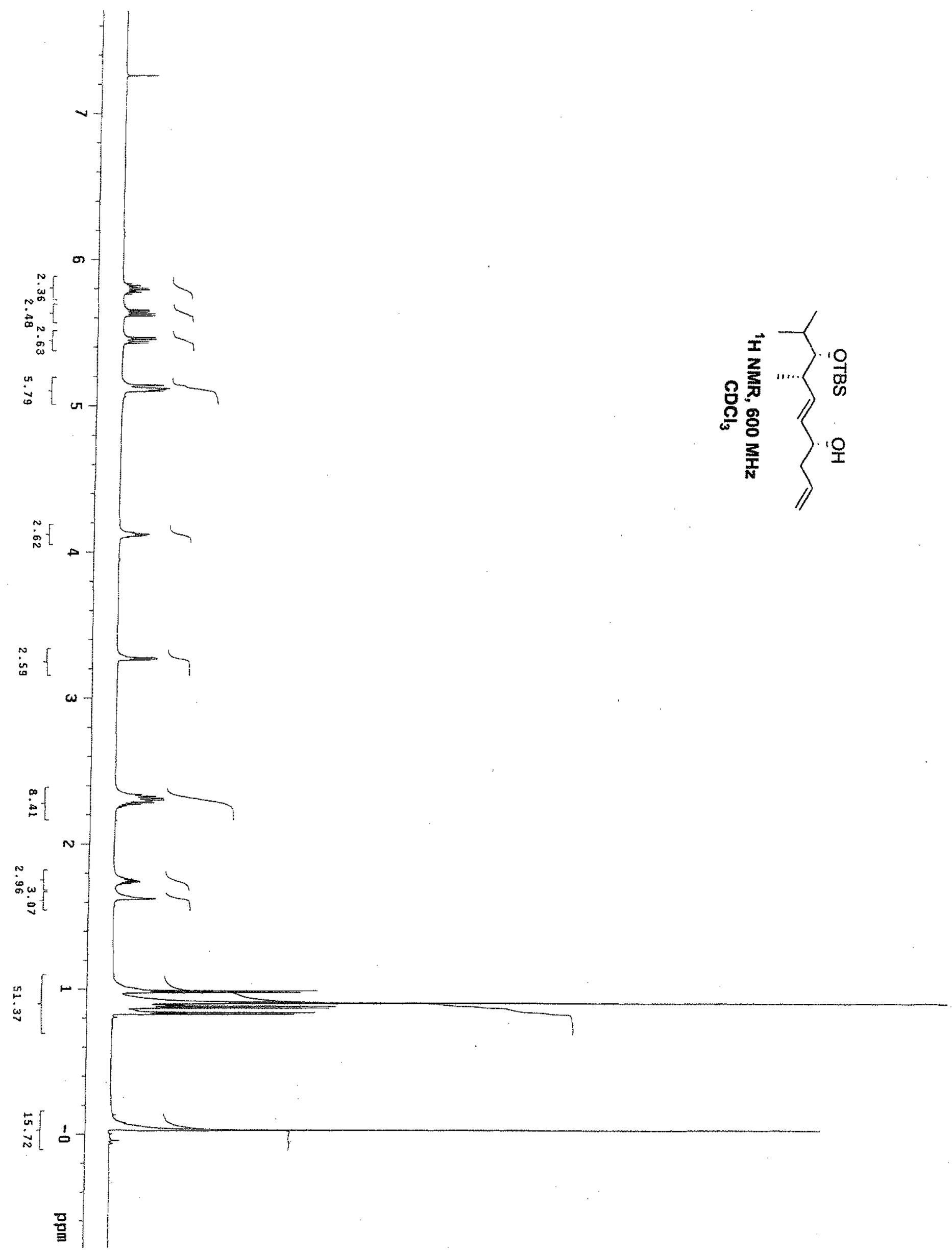




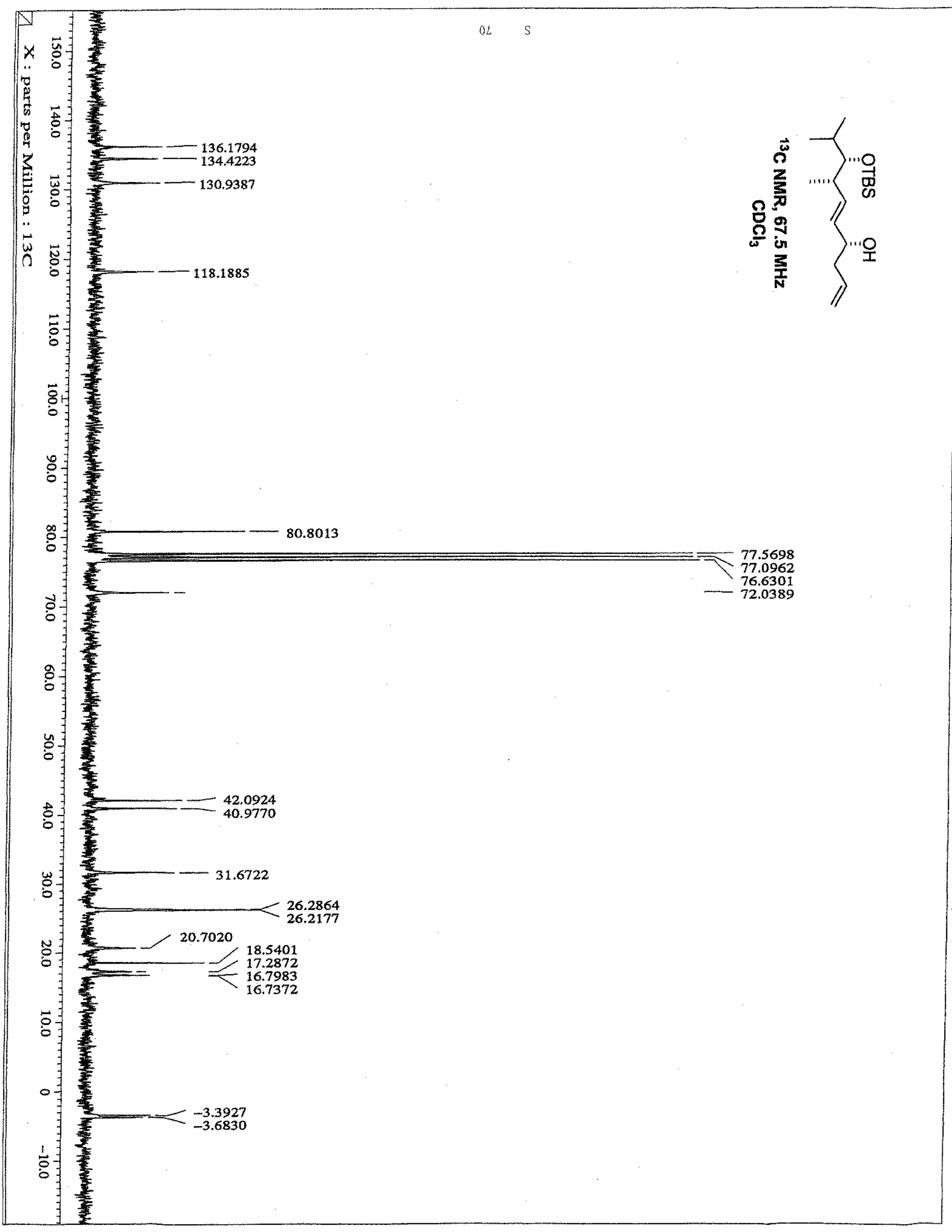




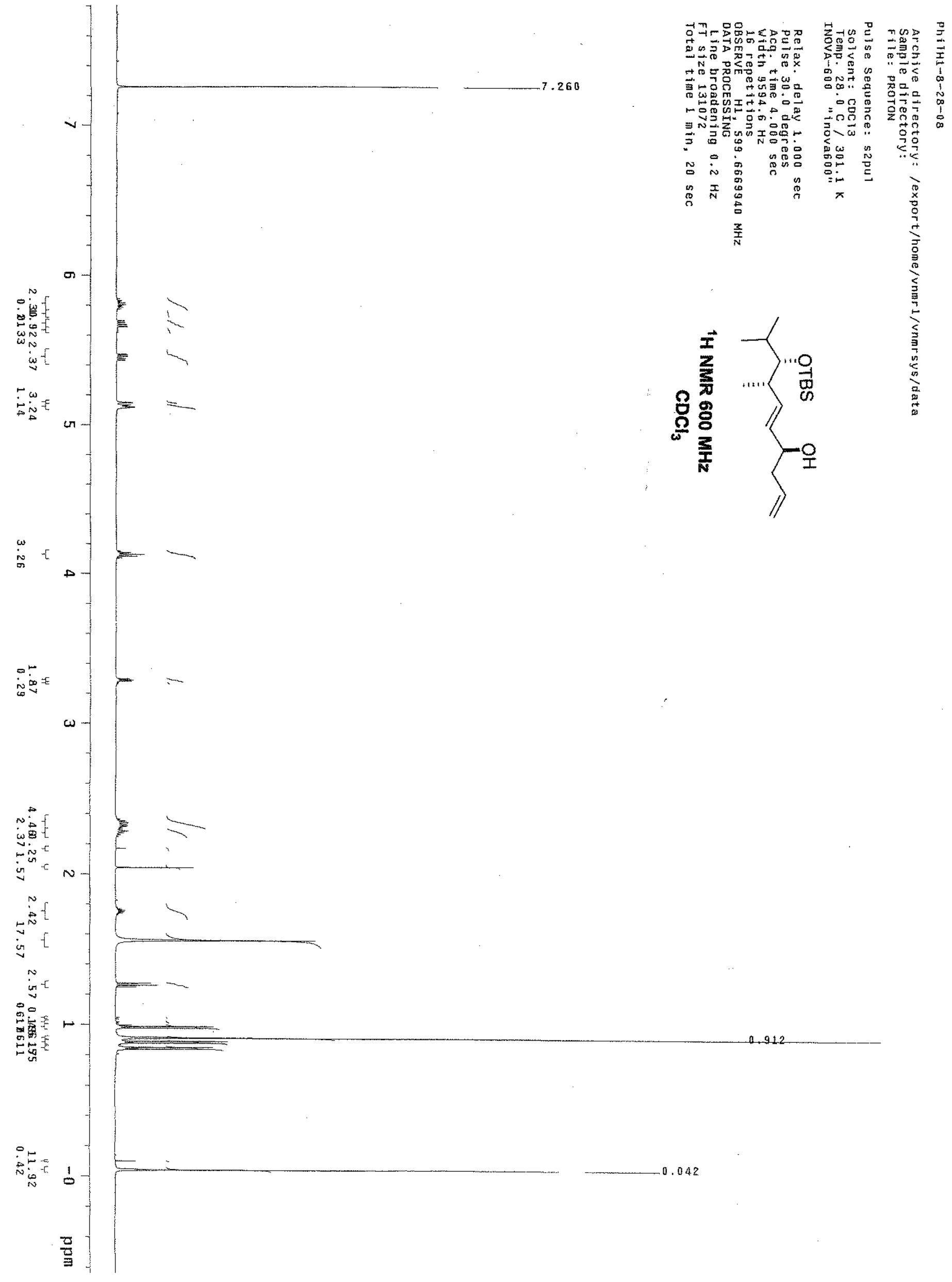




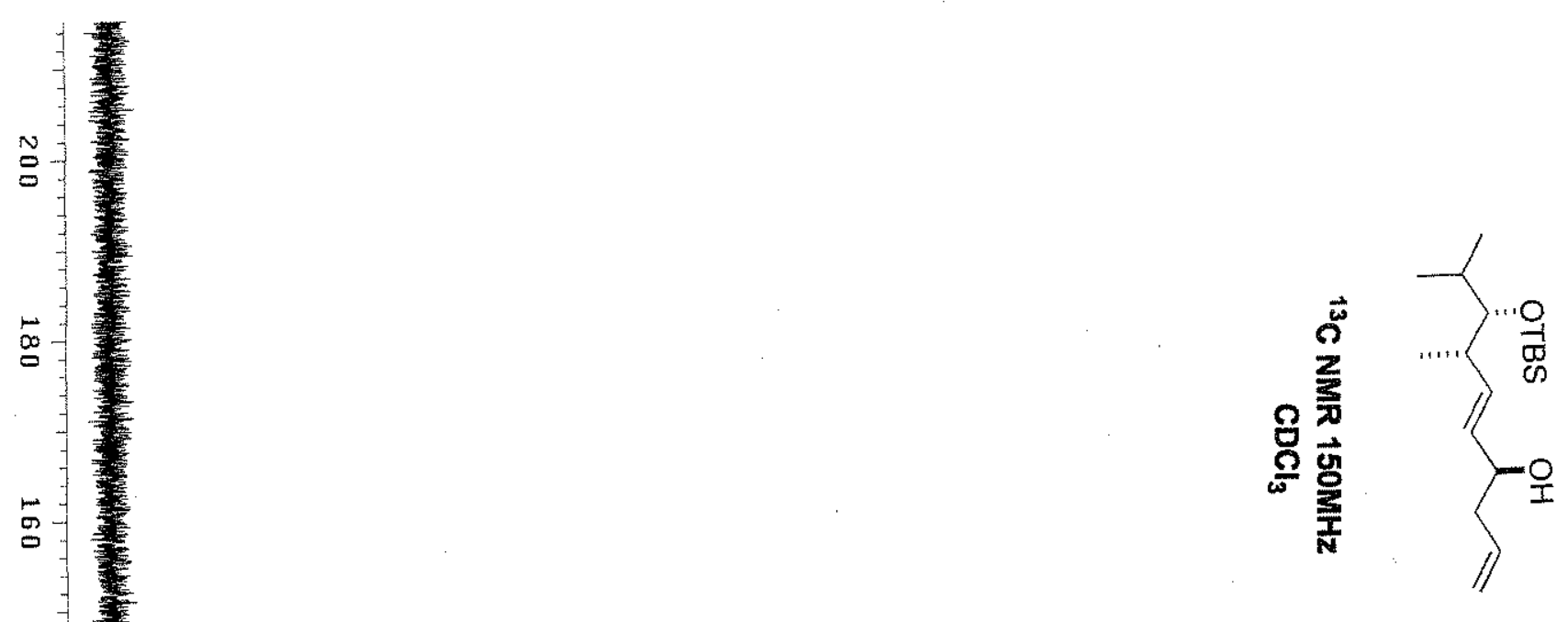

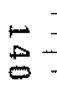

N

흠

언.

$\stackrel{\infty}{\circ}$

a

름
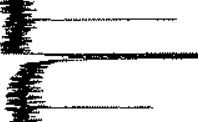
w

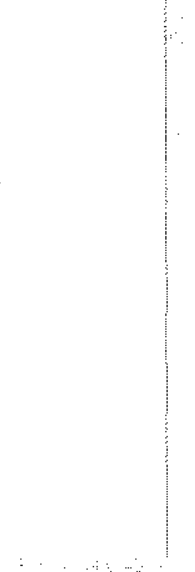

$\alpha \omega_{0}$

है

in $\quad$ u 8

i̊

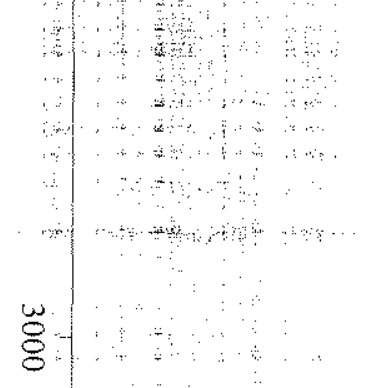

.

$\therefore+$

and

$\sqrt[3 n t]{3}$

a

सिक्षित्य

तrat

tis

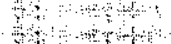

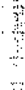

8

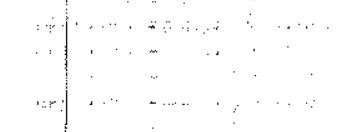

-

8

tons

$\therefore$.

W

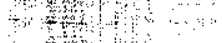

th

समत

a

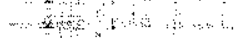

t.

(1)

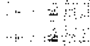

$+4 \ldots+\ldots$

a

8

का का
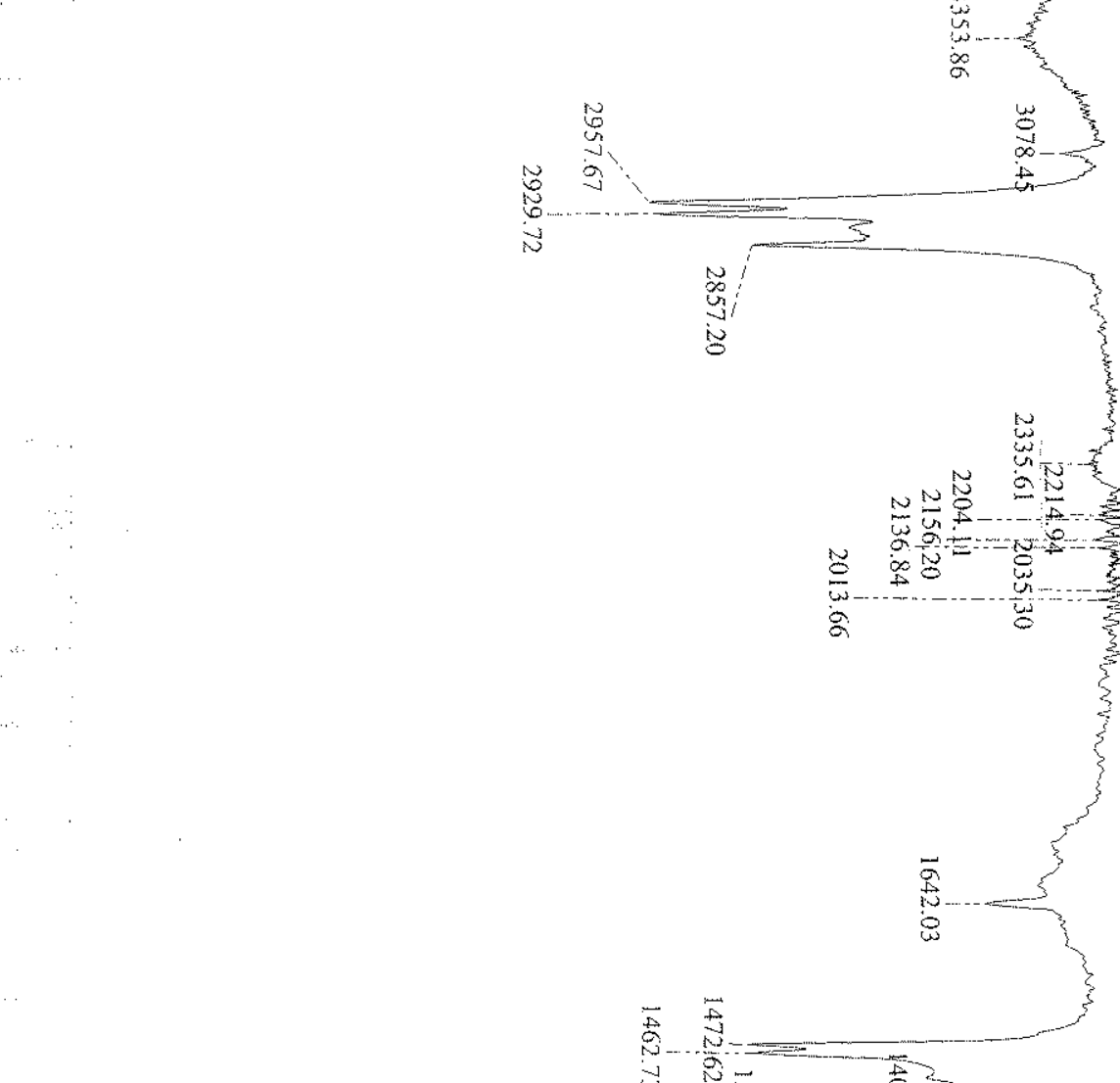

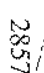

:
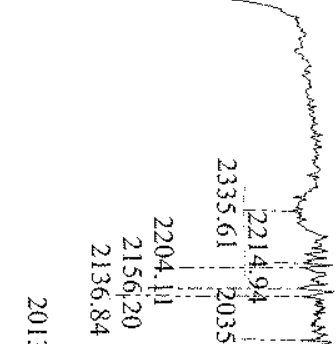

8

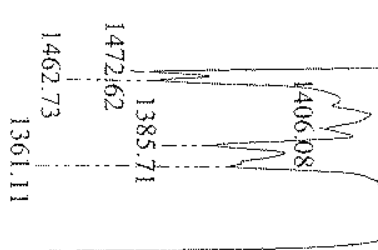

$\therefore \quad:$
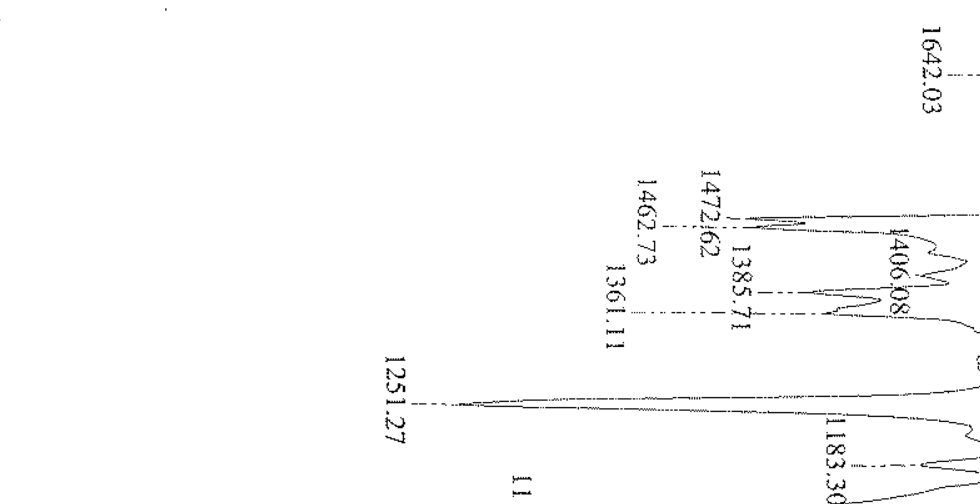

$-$

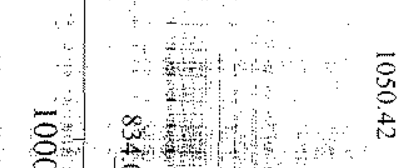

嫁

and

品

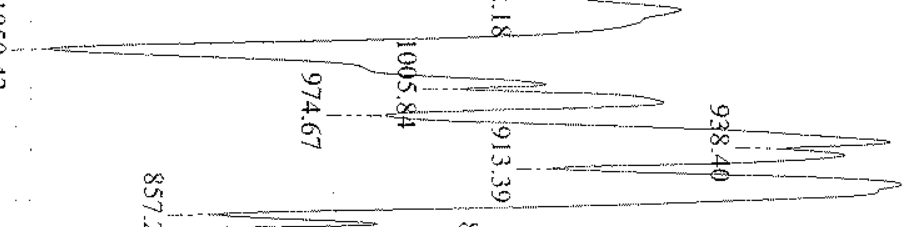

. 1

$-\frac{1}{4+1}$

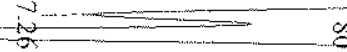

8

$-=$

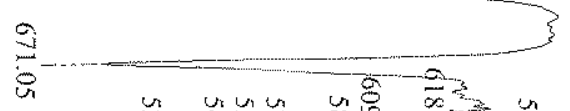

a

a)

प 4

Un
U
0

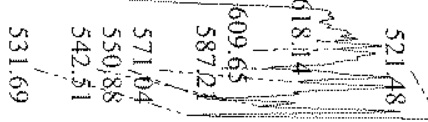




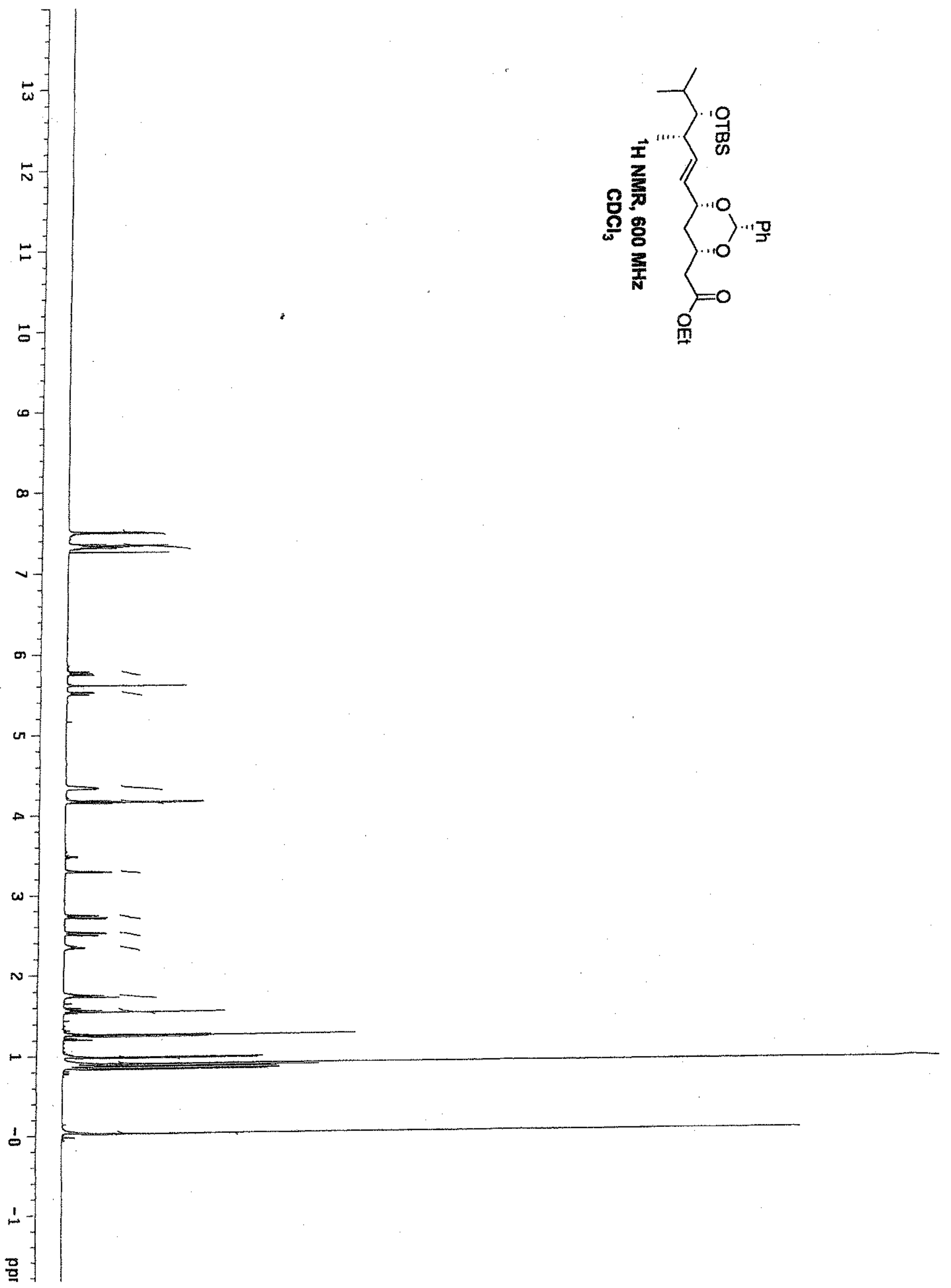




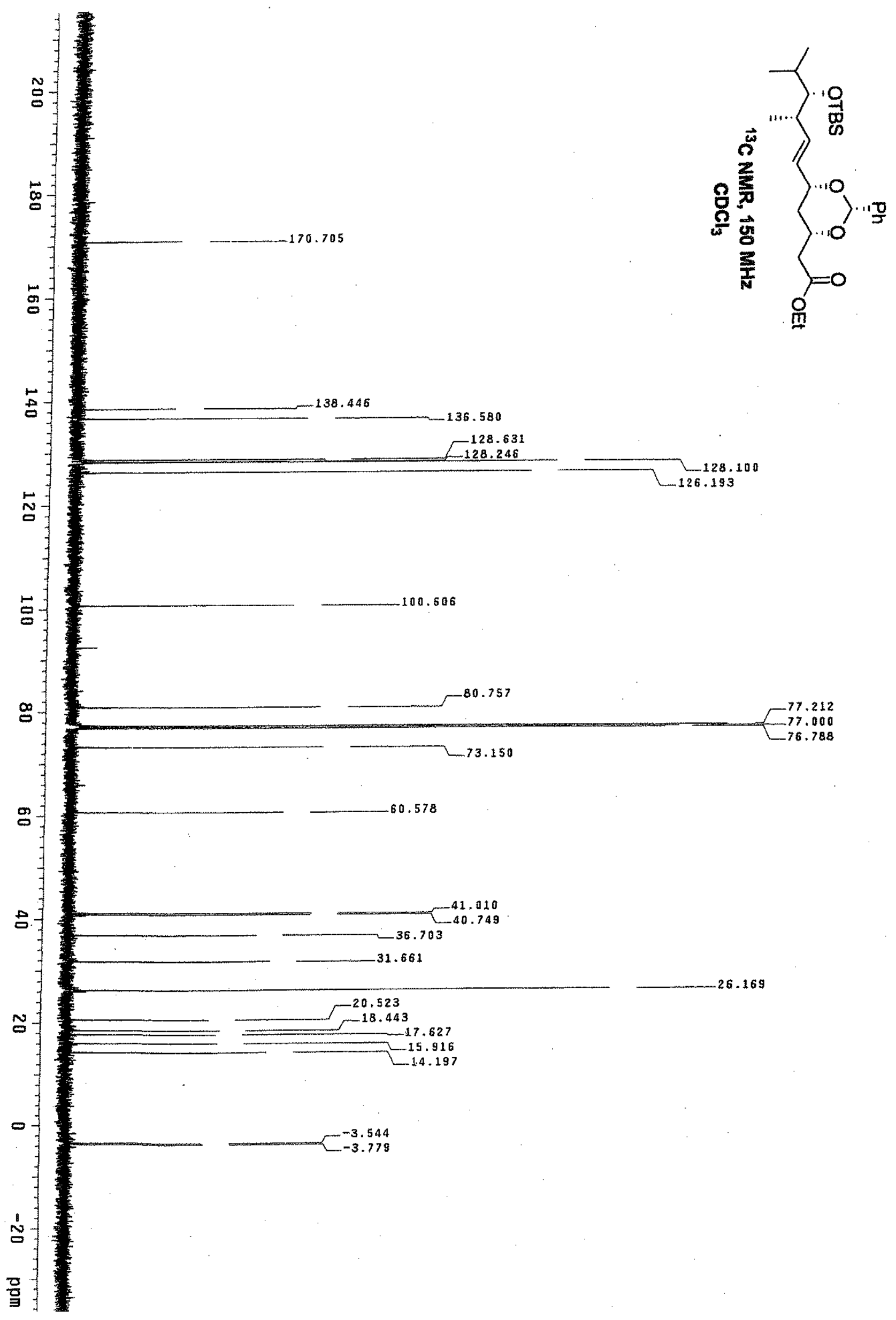




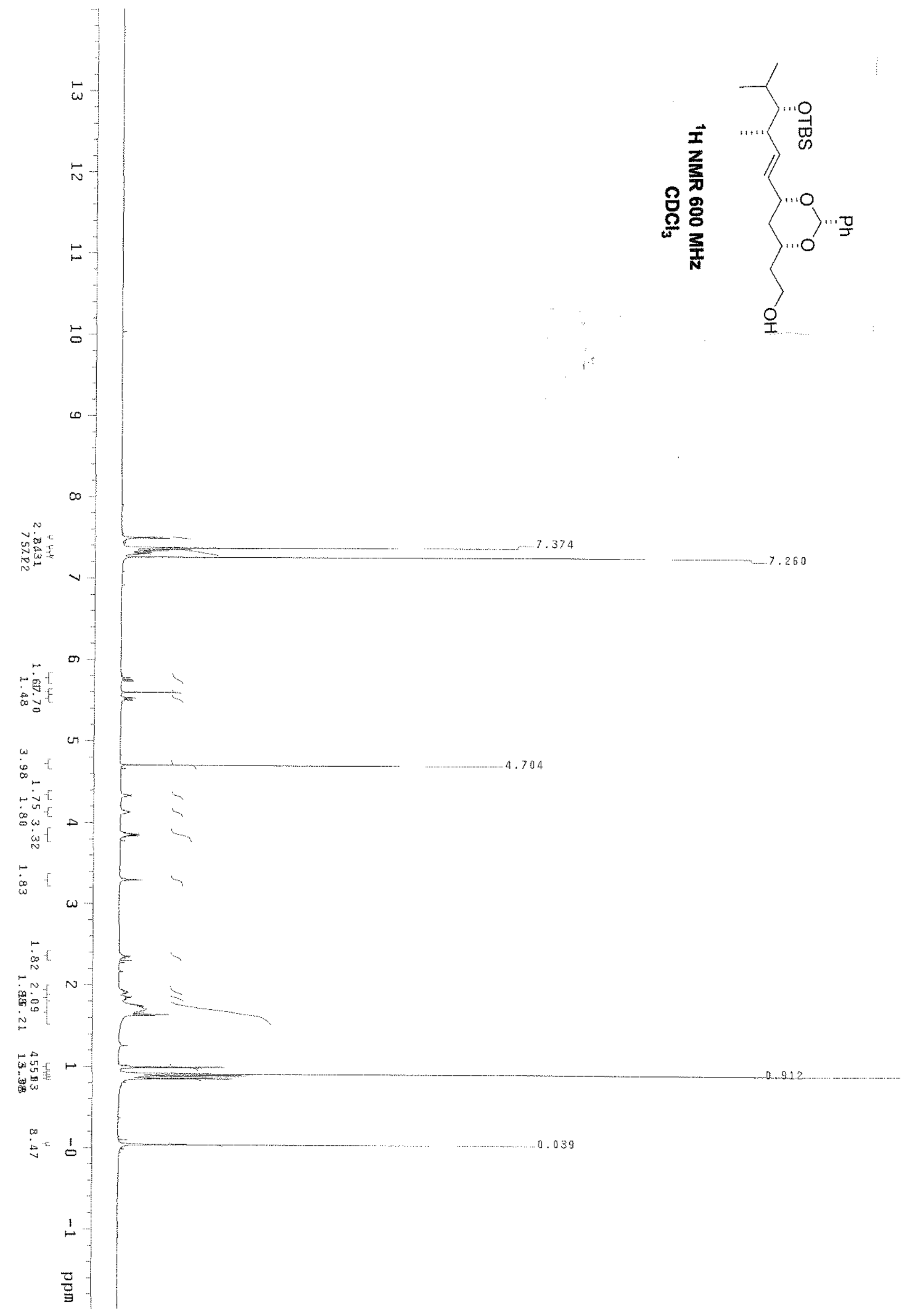




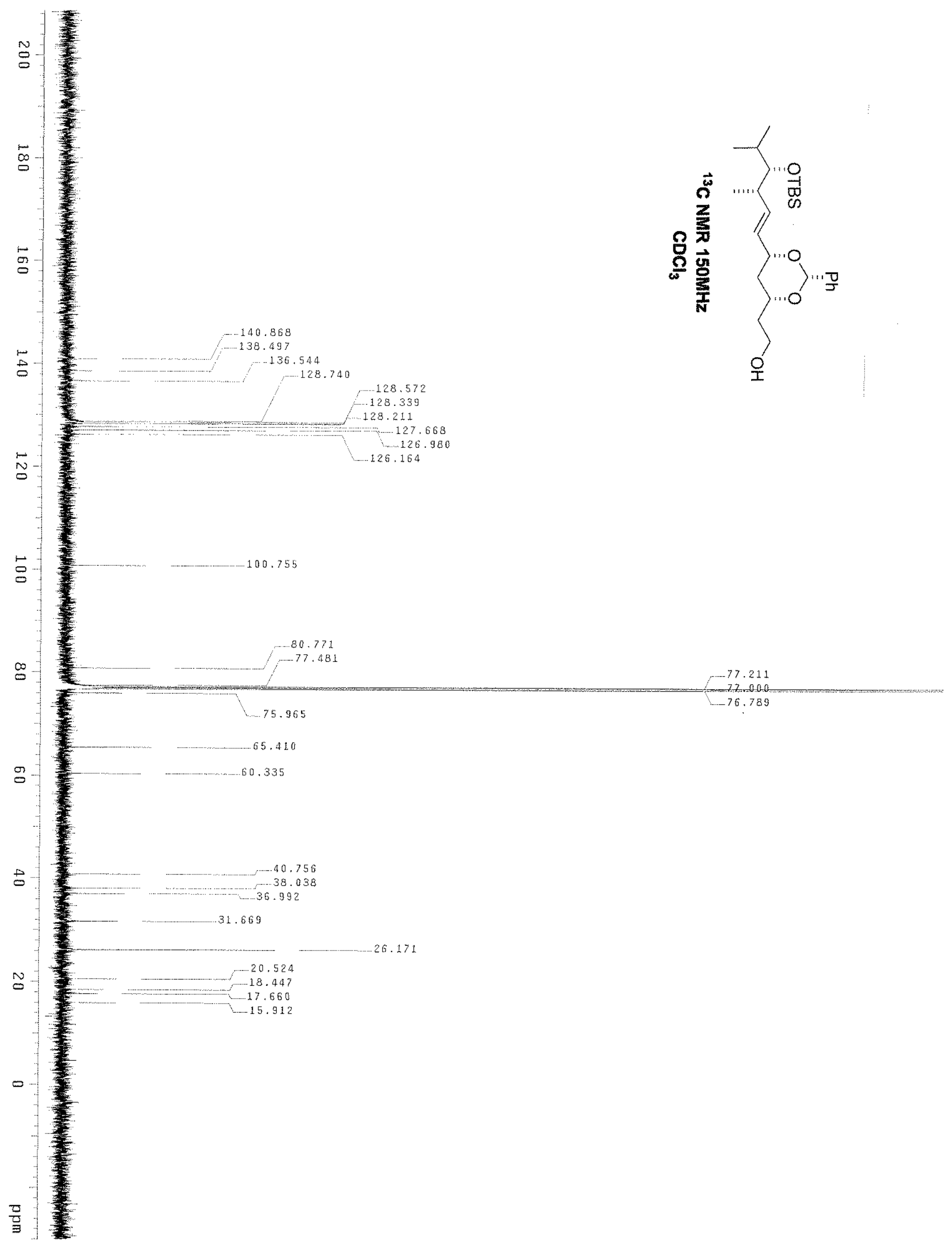




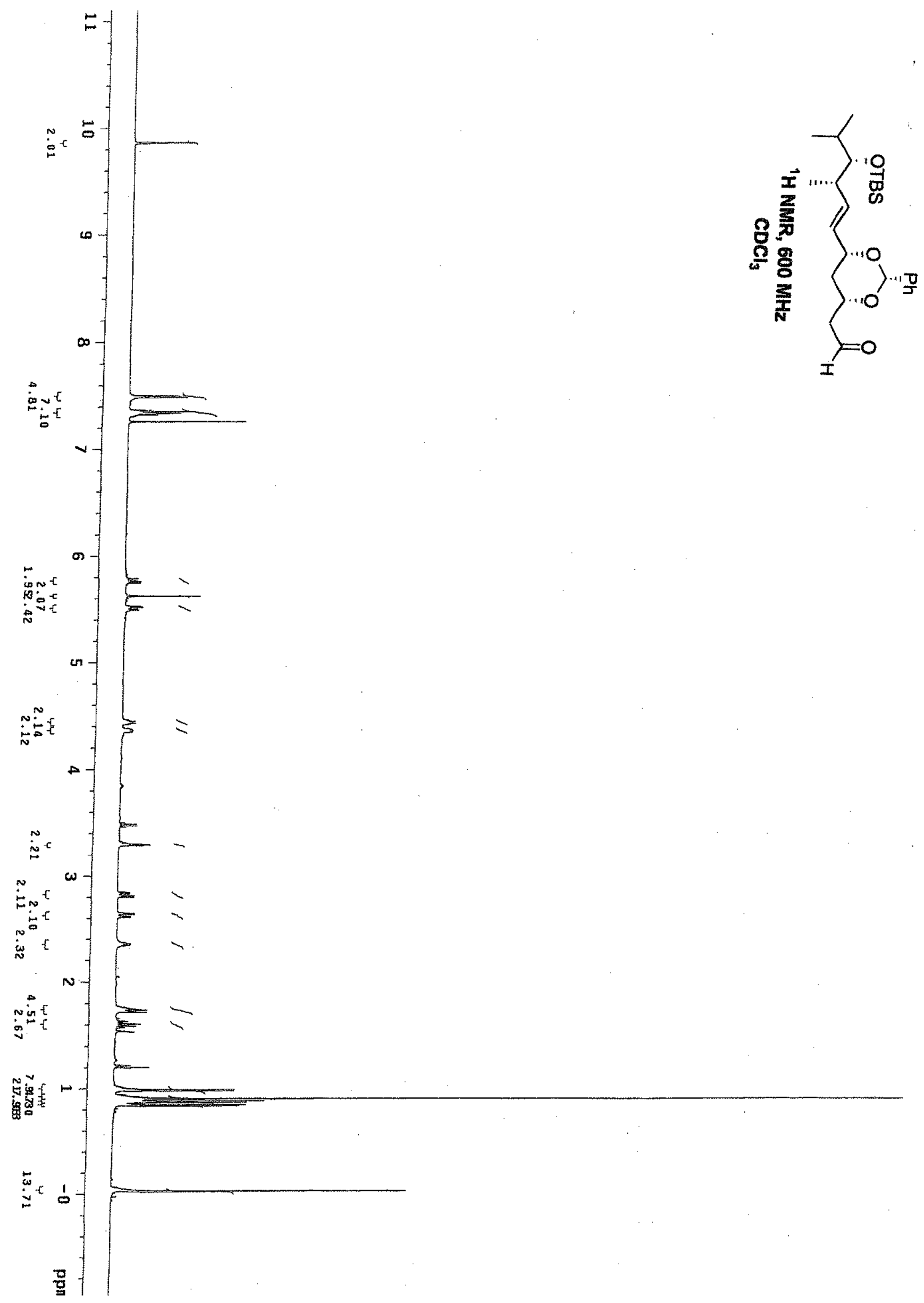




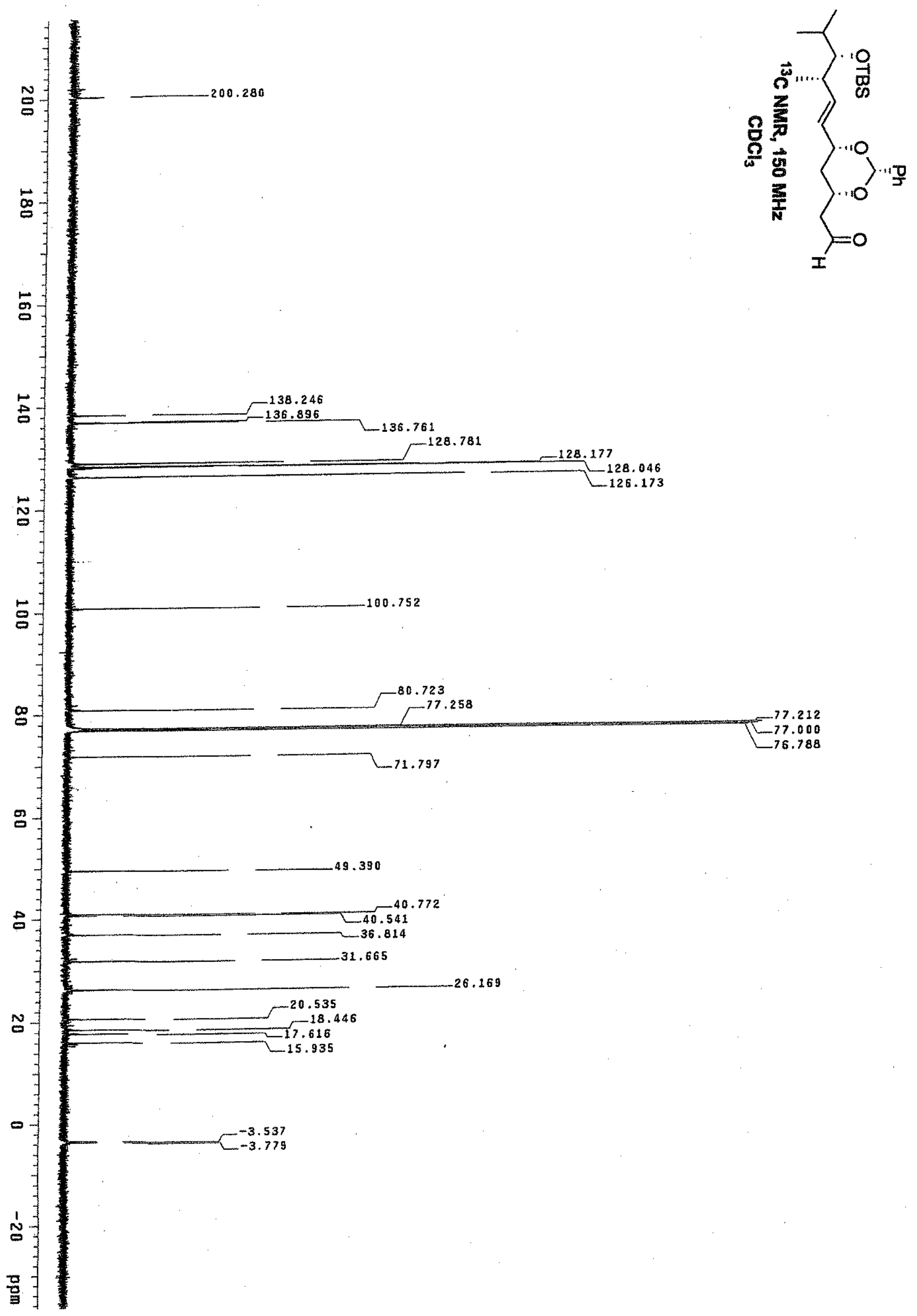




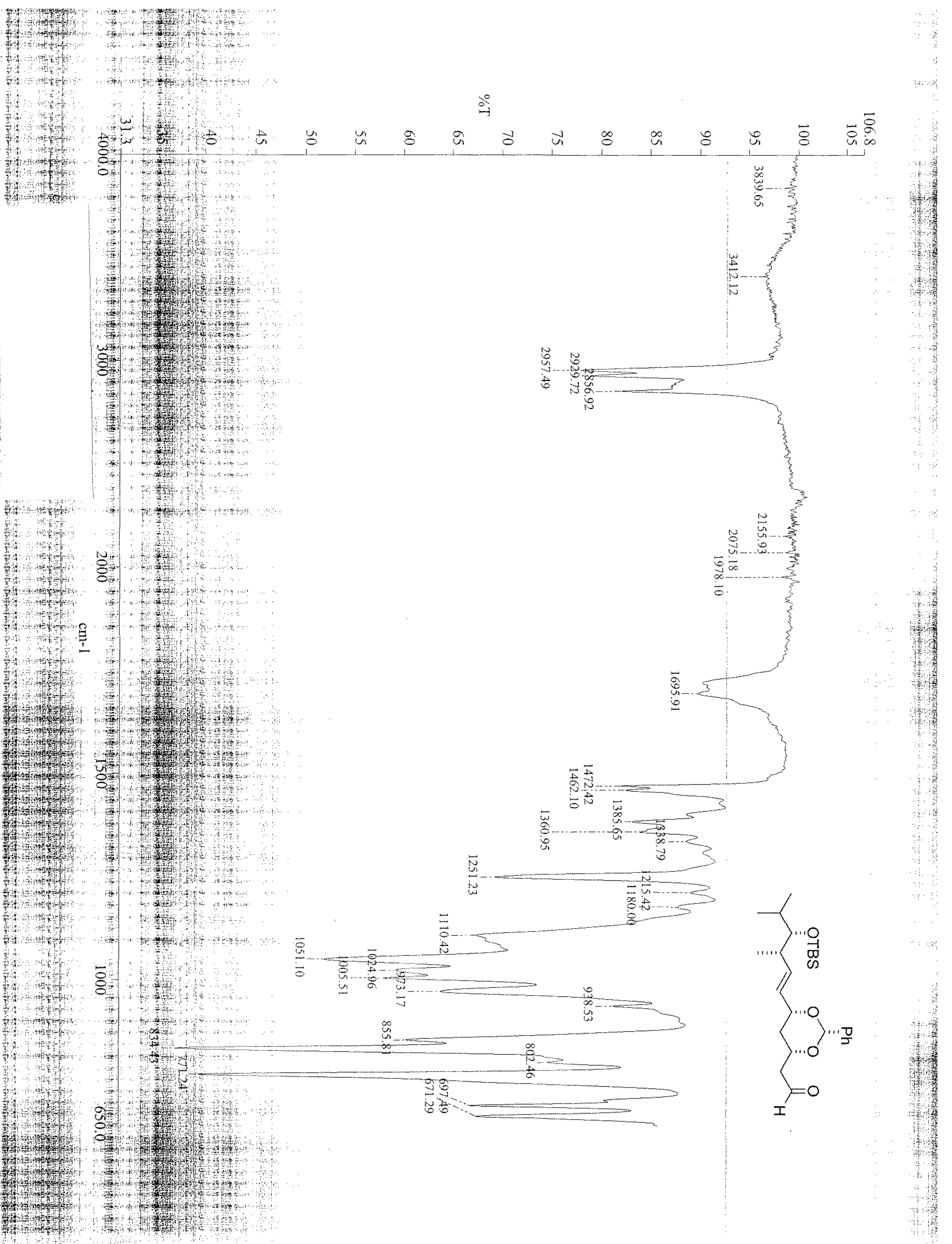


$L L \quad S$

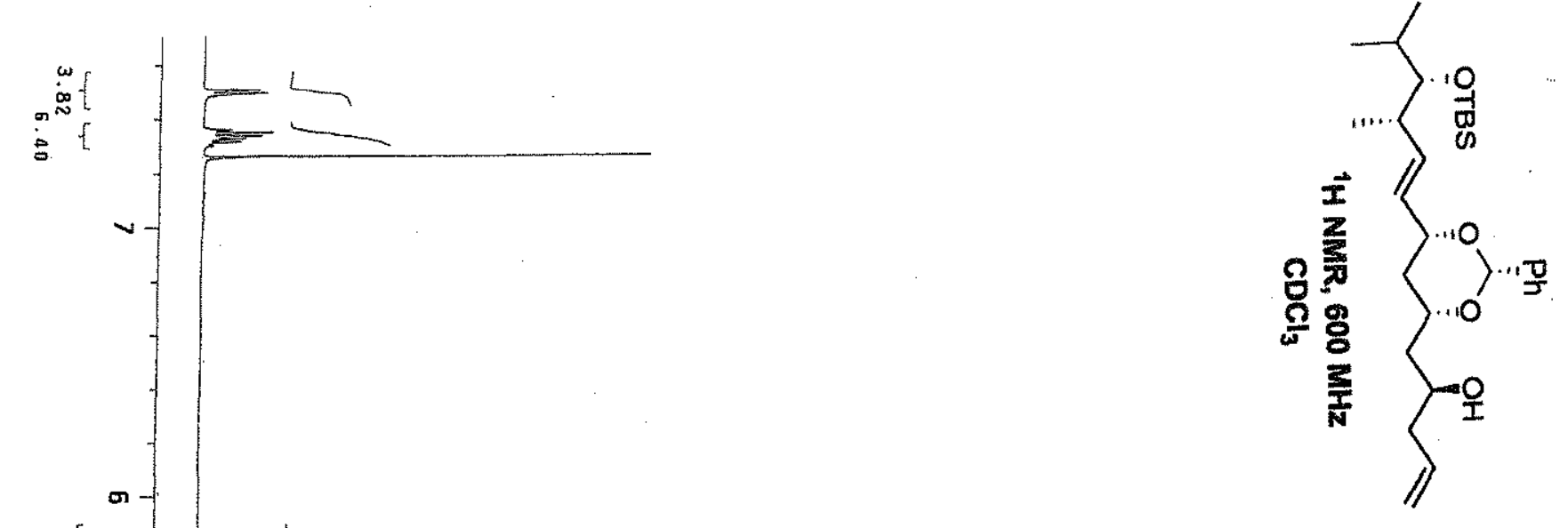




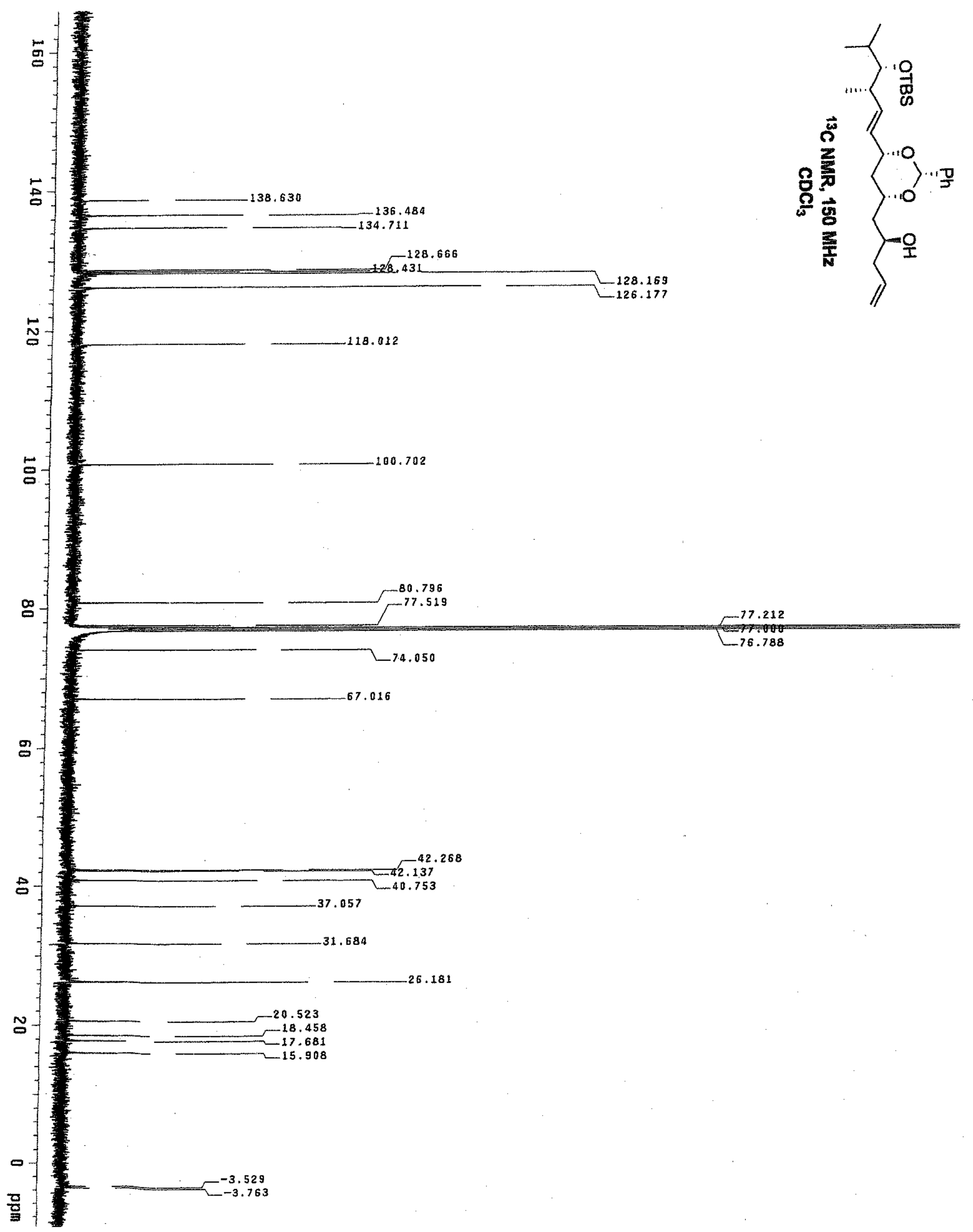

